\title{
Investigation of the role of prion protein in protection against transition metal induced toxicity
}

\author{
Ph.D. Thesis \\ Pradeep Kumar Reddy Cingaram
}

Supervisor: Dr. Ervin Welker

Co-supervisor: Dr. Elfrieda Fodor

\begin{abstract}
Doctoral School of Biology
University of Szeged

Institute of Biochemistry

Biological Research Center of the Hungarian Academy of Sciences
\end{abstract}

Szeged, 2016 


\section{Table of contents}

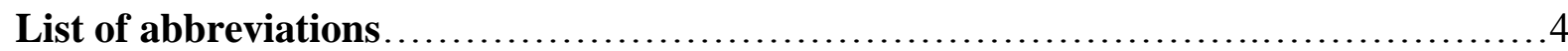

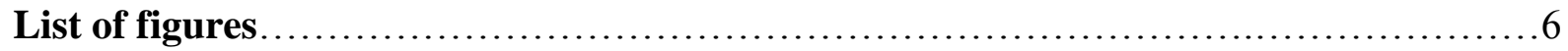

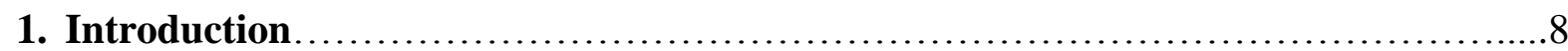

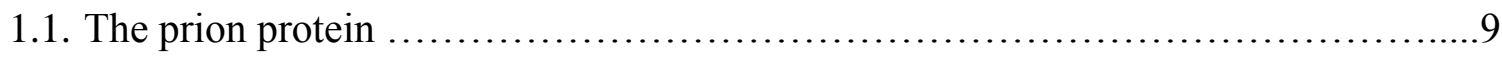

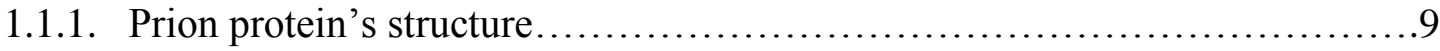

1.1.2. PRNP and its paralogs ............................................... 11

1.1.3. Prion protein localization............................................. 14

1.1.4. Trafficking: $\operatorname{PrP}^{\mathrm{C}}$ endocytosis pathways.............................. 14

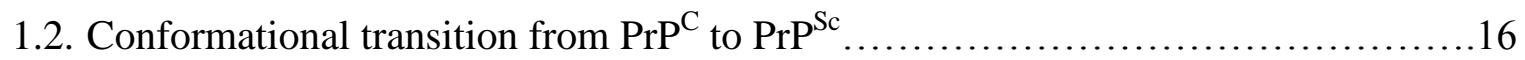

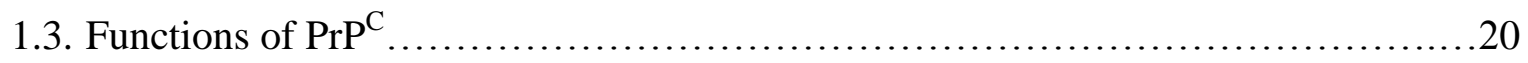

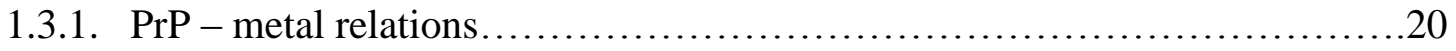

1.3.2. Role of divalent cations in the pathogenesis of prion diseases...............23

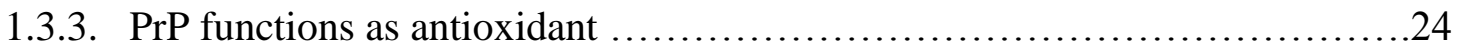

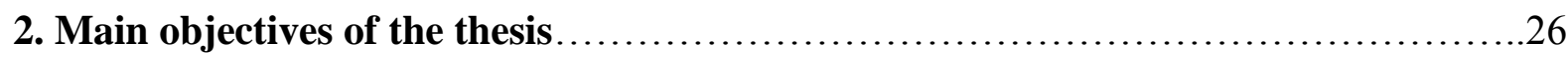

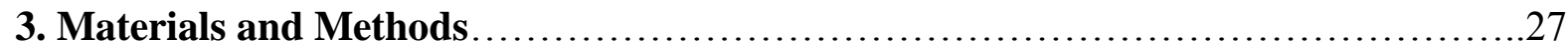

3.1. Reagents and antibodies.................................................. 27

3.2. Cell culturing, transfection and generation of stable cell lines....................27

3.3. Western blot analysis ...................................................... 28

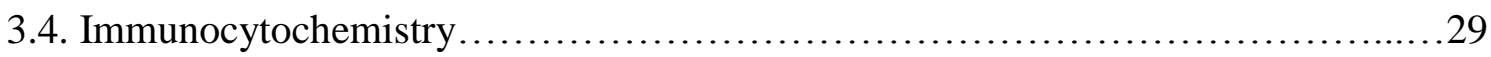

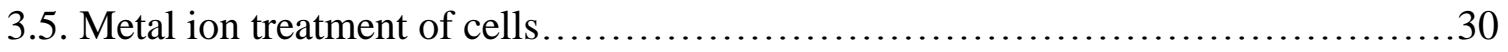

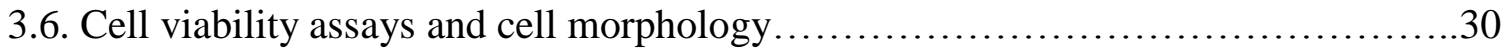

3.7. Cell-death assays........................................................ 31

3.8. Statistical analysis ........................................................ 31 
4.1 ZW 13-2 cells are significantly more resistant to $\mathrm{Cu}^{2+}, \mathrm{Zn}^{2+}, \mathrm{Mn}^{2+}$ and $\mathrm{Co}^{2+}$ induced toxicities than Zpl 2-1 cells

4.2 ZW 13-2 cells are morphologically less affected by $\mathrm{Cu}^{2+}, \mathrm{Zn}^{2+}, \mathrm{Mn}^{2+}$ and $\mathrm{Co}^{2+}$ induced stresses than Zpl 2-1 cells....

4.3 Generation of stable prion protein expressing Prnp $^{-/-}$(Zpl 2-1) neuronal cell lines..40 4.4 Zpl 2-1-PrP cells are not significantly more resistant to $\mathrm{Cu}^{2+}, \mathrm{Zn}^{2+}, \mathrm{Mn}^{2+}$ and $\mathrm{Co}^{2+}$ induced toxicities than its control Zpl 2-1-vector cells .44

4.5 $\mathrm{Zpl} 2-1-\mathrm{PrP}$ cells are not less affected morphologically by $\mathrm{Cu}^{2+}, \mathrm{Zn}^{2+}, \mathrm{Mn}^{2+}$ and $\mathrm{Co}^{2+}$ induced stresses than its control Zpl 2-1-vector cells

4.6 Zpl 2-1-PrP cells are not more resistant to $\mathrm{Cu}^{+2}, \mathrm{Zn}^{+2}$ and $\mathrm{Co}^{+2}$ induced cell death than Zpl 2-1-vector cells, whereas, PrP expressing ZW cells are more resistant compared to the PrP ablated Zpl 2-1 cells.

4.7 SH-SY5Y-PrP cells are significantly more resistant to $\mathrm{Cu}^{2+}$ and $\mathrm{Mn}^{2+}$ induced toxicities than SH-SY5Y and SH-SY5Y-vector cells

5. Discussion

6. Conclusions . .75

7. References. .77

8. Acknowledgement .89

9. Summary. .91

10. Összefoglalás . .93

11. Appendix .95 


\section{List of abbreviations}

aa: Amino acids

BSA: Bovine serum albumin

BSE: Bovine spongiform encephalopathy

CJD: Creutzfeldt-Jakob disease

CNS: Central nervous system

CWD: Chronic wasting disease

DAPI: 4', 6-diamidino-2 phenylindole

DMEM: Dulbecco's Modified Eagle's Medium

ECL: Enhances chemiluminescence

EDTA: Ethylenediaminetetraacetic acid

ER: Endoplasmic reticulum

FFI: Fatal familial insomnia

GFP: Green fluorescent protein

GPI: Glycosyl-phosphatidylinositol

GSS: Gerstmann-Sträussler-Scheinker syndrome

HD: Hydrophobic domain

HRP: Horseradish peroxidase

IP: Immunoprecipitation

MEM: Minimum essential medium

NMR: Nuclear magnetic resonance spectroscopy

OR: Octa repeat

ORF: Open reading frame

PAGE: Polyacrylamide gel electrophoresis

PBS: Phosphate buffered saline 
PCR: Polymerase chain reaction

PK: Proteinase K

PNGase F: Peptide: N-glycosidase F

PrP: Prion protein

$\operatorname{PrP}^{\mathrm{C}}$ : Cellular prion protein

$\operatorname{PrP}^{\mathrm{Sc}}$ : Scrapie prion protein

SDS: Sodium dodecyl sulfate

Sho: Shadoo

SOD: Superoxide dismutase

Tris: Tris(hydroxymethyl)aminomethane

Triton X-100: t-octylphenoxypolyethoxyethanol

TSE: Transmissible spongiform encephalopathies

WT: Wild type 


\section{List of figures}

Figure 1. Structural features and biochemical properties of the cellular prion protein.........10

Figure 2. Schematic representation of the domain architecture of PrP family members......12

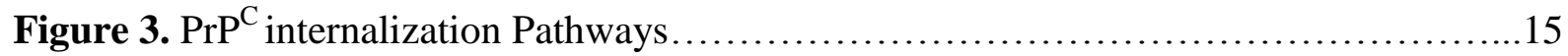

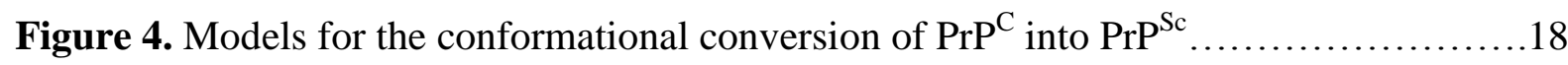

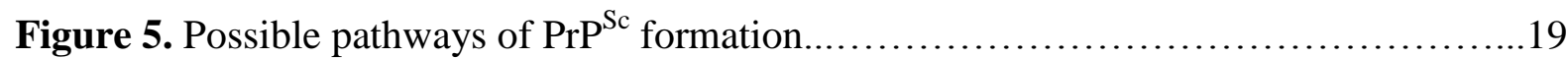

Figure 6. Immunoblotting performed to verify expression levels of $\mathrm{PrP}$ in the ZW 13-2 and Zpl 2-1 cell lines.

Figure 7. Immunocytochemistry verification of prion protein expression in $\mathrm{ZW} 13-2$ and $\mathrm{Zpl}$

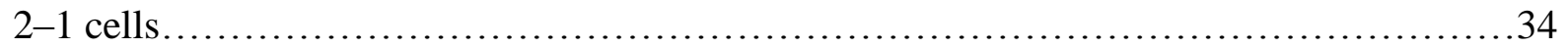

Figure 8. Sensitivity to transition metal-induced toxicity of ZW 13-2 and Zpl 2-1 cells....37

Figure 9. Morphological appearance of ZW 13-2 and Zpl 2-1 with $\mathrm{Cu}^{2+} \ldots \ldots \ldots \ldots \ldots . . . . .38$

Figure 10. Morphological appearance of ZW 13-2 and Zpl 2-1 with $\mathrm{Zn}^{2+} \ldots \ldots \ldots \ldots \ldots \ldots . \ldots 39$

Figure 11. Morphological appearance of ZW 13-2 and Zpl 2-1 with $\mathrm{Mn}^{2+} \ldots \ldots \ldots \ldots \ldots . . . .39$

Figure 12. Morphological appearance of ZW 13-2 and Zpl 2-1 with $\mathrm{Co}^{2+} \ldots \ldots \ldots \ldots \ldots . \ldots 39$

Figure 13. Western blotting performed to verify expression levels of $\operatorname{PrP}$ in the generated stable Zpl 2-1-vector and Zpl 2-1-PrP cell lines

Figure 14. Immunocytochemistry performed to verify prion protein expression in Zpl 2-1PrP and Zpl 2-1-vector cells

Figure 15. The percentage of PrP expressing cells in Zpl 2-1- PrP and Zpl 2-1-vector cells..43

Figure 16. The expression of $\mathrm{PrP}$ in $\mathrm{ZW} \mathrm{13-2} \mathrm{and} \mathrm{Zpl} \mathrm{2-1-PrP} \mathrm{stable} \mathrm{cell....}$

Figure 17. Relative expressions of PrP from ZW 13-2 and Zpl 2-1-PrP cell lines .44

Figure 18. The effect of the presence of $\operatorname{PrP}^{\mathrm{C}}$ on the susceptibility of cells to transition metalinduced toxicity..... 
Figure 19. Effect of $\operatorname{PrP}^{\mathrm{C}}$ expression on the susceptibility of cells to $\mathrm{Cu}^{2+}, \mathrm{Zn}^{2+}, \mathrm{Mn}^{2+}$ and

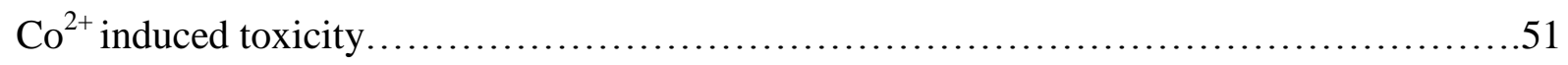

Figure 20. Morphological appearance of $\mathrm{Zpl} 2$-1-vector and $\mathrm{Zpl} 2-1-\mathrm{PrP}$ with $\mathrm{Cu}^{2+} \ldots \ldots . . .52$

Figure 21. Morphological appearance of $\mathrm{Zpl} 2-1$-vector and $\mathrm{Zpl} 2-1-\mathrm{PrP}$ with $\mathrm{Zn}^{2+} \ldots \ldots \ldots . .52$

Figure 22. Morphological appearance of $\mathrm{Zpl} 2-1$-vector and $\mathrm{Zpl} 2-1-\mathrm{PrP}$ with $\mathrm{Mn}^{2+} \ldots \ldots . .53$

Figure 23. Morphological appearance of $\mathrm{Zpl} 2-1$-vector and $\mathrm{Zpl} 2-1-\mathrm{PrP}$ with $\mathrm{Co}^{2+} \ldots \ldots . .53$

Figure 24. The effect of the presence of $\mathrm{PrP}^{\mathrm{C}}$ on $\mathrm{Cu}^{2+}$ transition metal induced cell death....55

Figure 25. The effect of the presence of $\mathrm{PrP}^{\mathrm{C}}$ on $\mathrm{Zn}^{2+}$ transition metal induced cell death....57

Figure 26. The effect of the presence of $\mathrm{PrP}^{\mathrm{C}}$ on $\mathrm{Mn}^{2+}$ transition metal induced cell death...58

Figure 27. The effect of the presence of $\mathrm{PrP}^{\mathrm{C}}$ on $\mathrm{Co}^{2+}$ transition metal induced cell death...59

Figure 28. Prion protein expression levels in stable SH-SY5Y-vector and SH-SY5Y-PrP cell

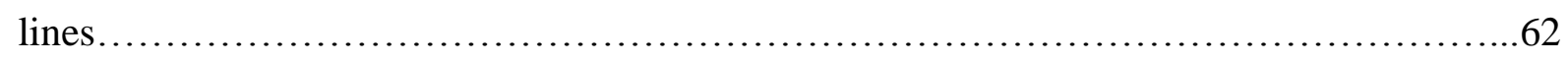

Figure 29. Effect of $\operatorname{PrP}^{\mathrm{C}}$ expression on resistance to transition metal-induced toxicity......65 


\section{Introduction}

Spongiform degeneration and neuronal loss are characteristic histopathological hallmarks found in the brains of individuals suffering from transmissible spongiform encephalopathy's (TSE) or prion diseases. Prion diseases are a family of rare and fatal neurodegenerative disorders that affect humans and many other mammals. They include Creutzfeldt-Jacob disease (CJD), Gerstmann Straussler syndrome (GSS), Familial Insomnia (FFI) and Kuru in humans, Bovine spongiform encephalopathy (BSE) in cattle, Chronic wasting disease (CWD) in deer and elk and scrapie in sheep (Aguzzi et al., 2008a; Collinge, 2001; Prusiner, 1996, 1998a, 1998b). Human forms of TSE's can be classified into three epidemiological categories, which count for different percentages of the observed cases: infectious (5\%), sporadic (80\%), and inherited (15\%) (McKintosh et al., 2003).

Prion diseases or TSEs are characterized by the deposition of an abnormal, protease resistant, infectious pathogenic "scrapie" isoform $\left(\mathrm{PrP}^{\mathrm{Sc}}\right)$ of the cellular prion protein $\left(\operatorname{PrP}^{\mathrm{C}}\right)$ in brain and in other tissues (Meyer et al., 1986). Apart of TSEs, accumulation of protein aggregates, mostly fibrillar, accompanying the breakdown of normal tissue morphology seems to be a common phenomenon in many diagnosed neurodegenerative diseases. For example, Alzheimer's disease (AD) is associated with the formation of $\beta$ - amyloidal (A $\beta$, amyloid $\beta$ ) plaques formed by the aggregation of the amyloid precursor protein (APP) (Selkoe, 1991). It has been observed that an increase in intracellular tau and phosphorylated tau leading to the breakdown of microtubules could also be a disease mechanism associated with AD (LaFerla et al., 2007). Parkinson's disease (PD) is associated with the formation of Lewy bodies produced by $\alpha$-synuclein (Jellinger, 2012). Finally, Huntington's (Htn) disease is caused by a mutation in the huntingtin gene (HTT) which leads to the production of fibrillar Htn plaques (Labbadia and Morimoto, 2013)(Aguzzi and Lakkaraju, 2015). The difference between TSE's compared to other neurodegenerative diseases is that they can be transmitted 
between hosts, whereas none of the other mentioned diseases have currently demonstrated any host to host transmission. Although all these diseases are associated with abnormal protein aggregation, it is generally not clear which aggregated state is responsible for the cell death (reviewed by Caughey and Lansbury, 2003). Growing evidence suggests the possibility of smaller size oligomers being responsible for cell damage and death, while larger fibrils may be more inert and even neuroprotective (Caughey and Lansbury, 2003). In case of TSEs additional challenge is to explain transmissibility, where the aggregated state of the infectious form of the prion protein may differ from the neurotoxic species (Caughey and Lansbury, 2003). Despite the wide-ranging neuropathological studies into prion diseases, neither the

mechanism by which $\operatorname{PrP}^{\mathrm{Sc}}$ causes neuronal dysfunction nor the normal function of $\operatorname{PrP}^{\mathrm{C}}$ is well defined. Although several functions have been recommended for the cellular isoform, $\operatorname{PrP}^{\mathrm{C}}$, there is no consensus upon its role or upon whether which of these functions would be primarily associated with prion disease pathogenesis or prion replication.

\subsection{The prion protein}

\subsubsection{Prion protein's structure}

The normal cellular isoform of the prion protein, $\operatorname{PrP}^{C}$, is a highly conserved, approximately 250 amino acid containing glycoprotein that is widely expressed in the body: predominantly in neurons and glia of the CNS and can also be found in several peripheral tissues, and leukocytes (Aguzzi and Polymenidou, 2004; Dodelet and Cashman, 1998). In humans, $\operatorname{PrP}^{\mathrm{C}}$ is encoded by a single exon of the PRNP gene located on the short arm of chromosome 20 (20p). $\operatorname{PrP}^{\mathrm{C}}$ possesses two N-glycosylation sites and is GPI-anchored to the outer leaflet of the plasma membrane (Stahl et al., 1987). The structural features of the protein are well summarized by Figure 1 ((Aguzzi et al., 2008b). 
a

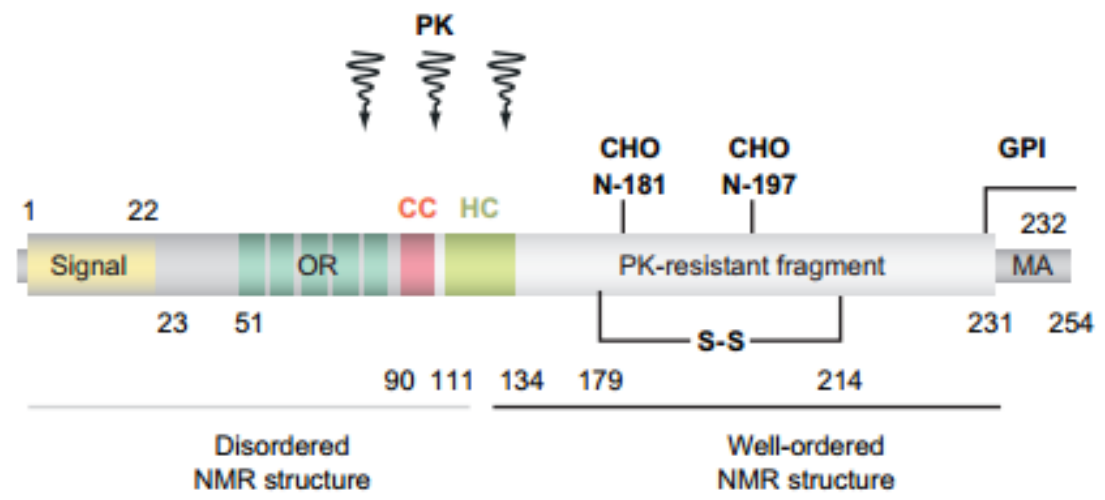

b

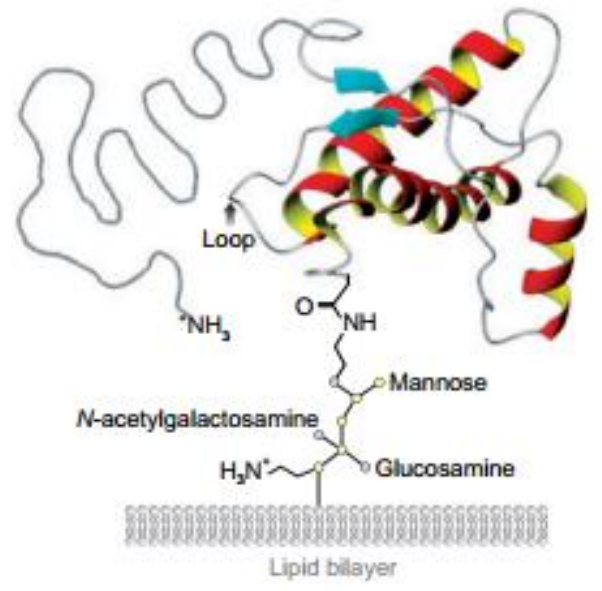

Biochemical properties

$\operatorname{PrPc}$

PrPse

Rich in $\alpha$-helices Rich in $\beta$-sheets

Soluble Insoluble

PK sensitive PK resistant

No aggregation Aggregation

Figure 1: Structural features and biochemical properties of the cellular prion protein. (A) Scheme of the primary structure of the cellular prion protein and its posttranslational modifications. A secretory signal peptide resides at the extreme $\mathrm{N}$ terminus. The numbers describe the positions of the respective amino acids. The proteinase $\mathrm{K}$ (PK)-resistant core of $\mathrm{PrP}^{\mathrm{Sc}}$ is depicted in gray; the approximate cutting site of $\mathrm{PK}$ within $\mathrm{PrP}^{\mathrm{Sc}}$ is indicated by arrows. CC (pink), charged cluster; HC (green), hydrophobic core; S-S, single disulfide bridge; MA, membrane anchor region; GPI, glycosylphosphatidylinositol; CHO, facultative glycosylation sites; NMR nuclear magnetic resonance. (B) Tertiary structure of the cellular prion protein, as figured out from NMR spectroscopy, inserted into a lipid bilayer, including the unstructured N-terminal tail (gray) and the GPI anchor. The $\alpha$-helices are indicated in red; the antiparallel $\beta$-sheets are shown in turquoise. Sugar residues are shown as colored small circles. (adapted from (Aguzzi et al., 2008b))

The biosynthesis pathway of the prion protein is similar to that of other membrane and secreted proteins. $\mathrm{PrP}^{\mathrm{C}}$ is synthesized at the rough endoplasmic reticulum (ER) during which it is subjected to post-translational modifications, including cleavage of the $\mathrm{N}$-terminal signal peptide (Figure 1a) and attachment of the GPI anchor following the cleavage of the C- 
terminal signal peptide. In the ER the protein is properly folded, including the formation of a single intramolecular di-sulphide bond, before it is transported to the Golgi system. In Golgi, two N-glycosylation reactions may optionally occur, where complex oligosaccharides are attached to the two Asn residues in the loop formed between the two Cys residues participating in the di-sulphide bond (Haraguchi et al., 1989). As a consequence, when the protein is transported from the Golgi to the outer leaflet of the plasma membrane $\operatorname{PrP}^{\mathrm{C}}$ can exist in unglycosylated, monoglycosylated, and diglycosylated forms (Westergard et al., 2007). Structurally (Figure 1b), the C-terminal domain of $\operatorname{PrP}^{C}$ is folded largely into $\alpha$-helices stabilized by a single di-sulphide bond and nuclear magnetic resonance (NMR) shows it exists in a monomeric state (Riek et al., 1996). Studies of the crystal structure of the C-terminal half of PrP revealed that it contains three $\alpha$-helices and a short anti-parallel $\beta$-sheet (Eghiaian et al., 2004; Haire et al., 2004; Knaus et al., 2001). Contrary, the N-terminal half is disordered. The N-terminal domain of PrP consists of positively charged amino acid sequences and an octapeptide repeat (OR) sequence (Figure 1a), which can bind $\mathrm{Cu}^{2+}, \mathrm{Zn}^{2+}$ and other transition metal ions suggesting a possible role of it in ion regulation/signaling (Hosszu et al., 1999; Jackson et al., 2001a; Riek et al., 1998). The middle region between residues 106-126, constitutes a highly conserved hydrophobic domain (HD) rich in alanine and valine.

\subsubsection{PRNP and its paralogs}

The human $P R N$ gene locus contains three genes: $P R N P, P R N D$, and a novel gene SPRN (Makrinou et al., 2002). The cellular prion protein $\left(\operatorname{PrP}^{\mathrm{C}}\right)$ is encoded by the PRNP gene as a single copy.

First prion-related gene is Doppel (Dpl) or "downstream prion protein-like gene," (Moore et al., 1999). The gene encoding Dpl, labeled PRND, is located at the same locus as the PRNP gene. It has been found that Dpl shares several structural and biochemical features 
with $\operatorname{PrP}^{\mathrm{C}}$ (Silverman et al., 2000). Dpl shows $25 \%$ primary sequence similarity with the Cterminus of $\operatorname{PrP}^{\mathrm{C}}$ (Figure 2) and both proteins are structurally similar, which has been revealed by NMR studies (Mo et al., 2001).

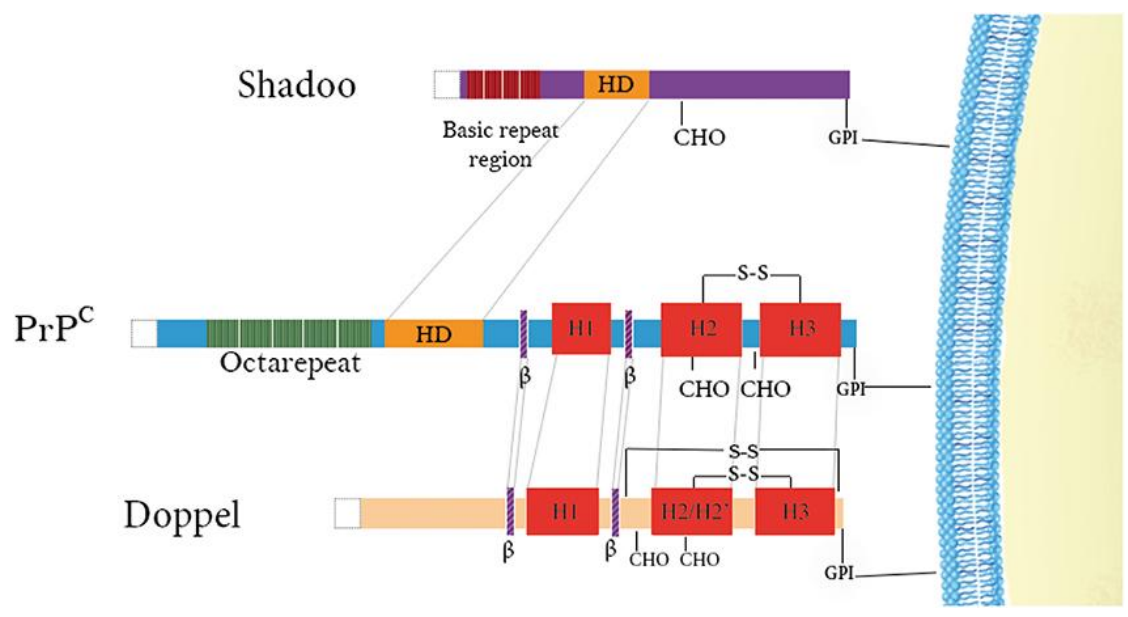

Figure 2: Schematic representation of the domain architecture of $\operatorname{PrP}$ family members. Doppel and $\operatorname{PrP}^{\mathrm{C}}$ have structured C-terminal domains consisting of $3 \alpha$-helices (in red) and 2 short $\beta$-strands (in purple) as well as positively-charged $\mathrm{N}$-terminal regions. Disulfide bridges are indicated above the proteins $(-\mathrm{S}-\mathrm{S}-$ ) and $\mathrm{N}$-glycosylation sites $(\mathrm{CHO})$ are denoted below the proteins. Repetitive regions are found in both $\operatorname{PrP}^{\mathrm{C}}$ (green) and Shadoo (dark red) with the former possessing octarepeats binding copper and the latter possessing tetrarepeats rich in arginine and glycine residues. A conserved hydrophobic domain is also illustrated in $\operatorname{PrP}^{\mathrm{C}}$ and Shadoo (yellow). N-terminal signal sequences (white) are cleaved in all of them. (adapted from (Ciric and Rezaei, 2015)).

Similarly to $\operatorname{PrP}^{\mathrm{C}}$, Dpl also has two N-glycosylation sites and a glycosylphosphatidylinositol (GPI) anchor, which results in a similar localization in the outer surface of the plasma membrane. Since Dpl was discovered, much attention has been devoted to Dpl research. In particular, the study of Dpl-induced cerebellar neurodegeneration, that has demonstrated the importance of the $\mathrm{N}$-terminal domain of $\operatorname{PrP}^{\mathrm{C}}$ in neuroprotection. In fact, expression of $\mathrm{N}$-terminally truncated form of $\operatorname{PrP}[\operatorname{PrP}(\Delta 32-121)$ or $\operatorname{PrP}(\Delta 32-134)]$ in $\operatorname{Prnp}^{0 / 0}$ mice (Flechsig et al., 2003) leads to ataxia and Purkinje cell loss in the same fashion as Dpl ectopic expression (Anderson et al., 2004). The cytotoxic effects of $\Delta \mathrm{PrP}$ $(\Delta 32-121$ or $\Delta 32-134)$ and of Dpl are rectified by full-length PrP (Cui et al., 2003; Nishida 
et al., 1999; Yamaguchi et al., 2004), suggesting common molecular mechanisms for the truncated forms of PrP and Dpl, most likely of interfering in some cellular pathways essential for cell survival, in which the full-length PrP is involved as with an anti-apoptotic activity (Shmerling et al., 1998; Watts and Westaway, 2007).

A nascent protein product encoded by SPRN ORF is another member of PrP family (Figure 2). The new prion-related gene outside of PRN locus was discovered by Premzl in 2003 during an exploration for potential homologs of PrP in the NCBI non-redundant protein database. The SPRN gene, encoding for a protein designated as shadow of prion protein (Shadoo, Sho), is found to be highly conserved from fish to mammals (Premzl et al., 2003). As the name suggests, Sho, the shadow protein of PrP, has several characteristic features that resemble that of $\operatorname{PrP}^{\mathrm{C}}$. Structurally there are two features which exists in both Shadoo and the PrP's natively unstructured N-terminus: i) a series of positively charged tandem repeats with short sequences ii) a hydrophobic domain (HD) (Figure 2). Also, like the other two members, Sho carries a GPI anchor signal sequences and one or two N-glycosylation sites which were experimentally confirmed on the endogenous protein in brain homogenates (Miesbauer et al., 2006; Watts et al., 2007). Besides these structural similarities, several other correlations have been identified. Both proteins are mainly expressed in the brain, with both overlapping and differential expression areas: Sho expression overlaps $\operatorname{PrP}^{\mathrm{C}}$, but is low in cerebellar granular neurons (CGNs) containing $\operatorname{PrP}^{\mathrm{C}}$ and high in $\mathrm{PrP}^{\mathrm{C}}$-deficient dendritic processes (Lampo et al., 2007; Premzl et al., 2003; Watts et al., 2007). Importantly, the expression levels between $P R N P$ and SPRN mRNA showed a highly significant positive correlation in sheep cerebrum and cerebellum tissues, suggesting a co-regulation of the genes in these tissues (Lampo et al., 2009). Specially, while the infectious particle $\operatorname{PrP}^{\mathrm{Sc}}$ accumulated, both $\operatorname{PrP}^{\mathrm{Sc}}$-infected animals and infected neuroblastoma cells showed extremely decreased levels of Sho protein (Watts et 
al., 2007, 2011; Westaway et al., 2011). Taking these findings together, Sho seems to show a functional link with PrP and could take part in the process of prion diseases.

\subsubsection{Prion protein localization}

In order to identify the intracellular compartments and the mechanisms that underlie the formation of prion disease, it is essential to know the precise cellular localizations of $\operatorname{Pr} \mathrm{P}^{\mathrm{C}}$ and $\operatorname{PrP}^{\mathrm{Sc}}$. As a natively GPI-anchored protein, the major sites of $\operatorname{PrP}^{\mathrm{C}}$ localization include: the ER, Golgi, plasma membrane, exosomes, and endolysosomes, however, , PrP was also reported in the cytosol and the nucleus as a result of misprocessing by the ER (Fevrier et al., 2004; Magalhães et al., 2002; Mangé et al., 2004; Mironov et al., 2003; Sarnataro et al., 2002, 2004). Currently, there is a substantial gap in our understanding of $\operatorname{PrP}^{\mathrm{Sc}}$ localization as there are no specific antibodies for $\mathrm{PrP}^{\mathrm{Sc}}$. However, studies suggest a wide cellular distribution, in particular at the plasma membrane and in the endolysosomal compartment (Arnold et al., 1995; Caughey and Raymond, 1991; Jeffrey et al., 1992). Under certain situations, it have been reported that $\mathrm{PrP}^{\mathrm{Sc}}$-like structures will accumulate in the cytosol and there is also evidence for cytosolic $\mathrm{PrP}^{\mathrm{Sc}}$-containing aggresomes in prion-infected cells following the proteasome inhibition (Kristiansen et al., 2005; Ma and Lindquist, 2002).

\subsubsection{Trafficking: $\operatorname{PrP}^{\mathrm{C}}$ endocytosis pathways}

Following synthesis in the ER, $\operatorname{PrP}^{\mathrm{C}}$ is trafficked via the Golgi to the cell surface, where it constitutively cycles between the plasma membrane and early endosomes (Shyng et al., 1993). Several mechanisms have been proposed to explain $\operatorname{PrP}^{\mathrm{C}}$ internalization (Campana et al., 2005) such as clathrin-mediated endocytosis, caveolin-associated endocytosis and raft dependent endocytosis (Figure 3). As the main route, $\operatorname{PrP}^{\mathrm{C}}$ has been shown to recycle from the 
cell surface to endosomes via clathrin-coated pits (Shyng et al., 1994; Sunyach, 2003; Taylor et al., 2005).

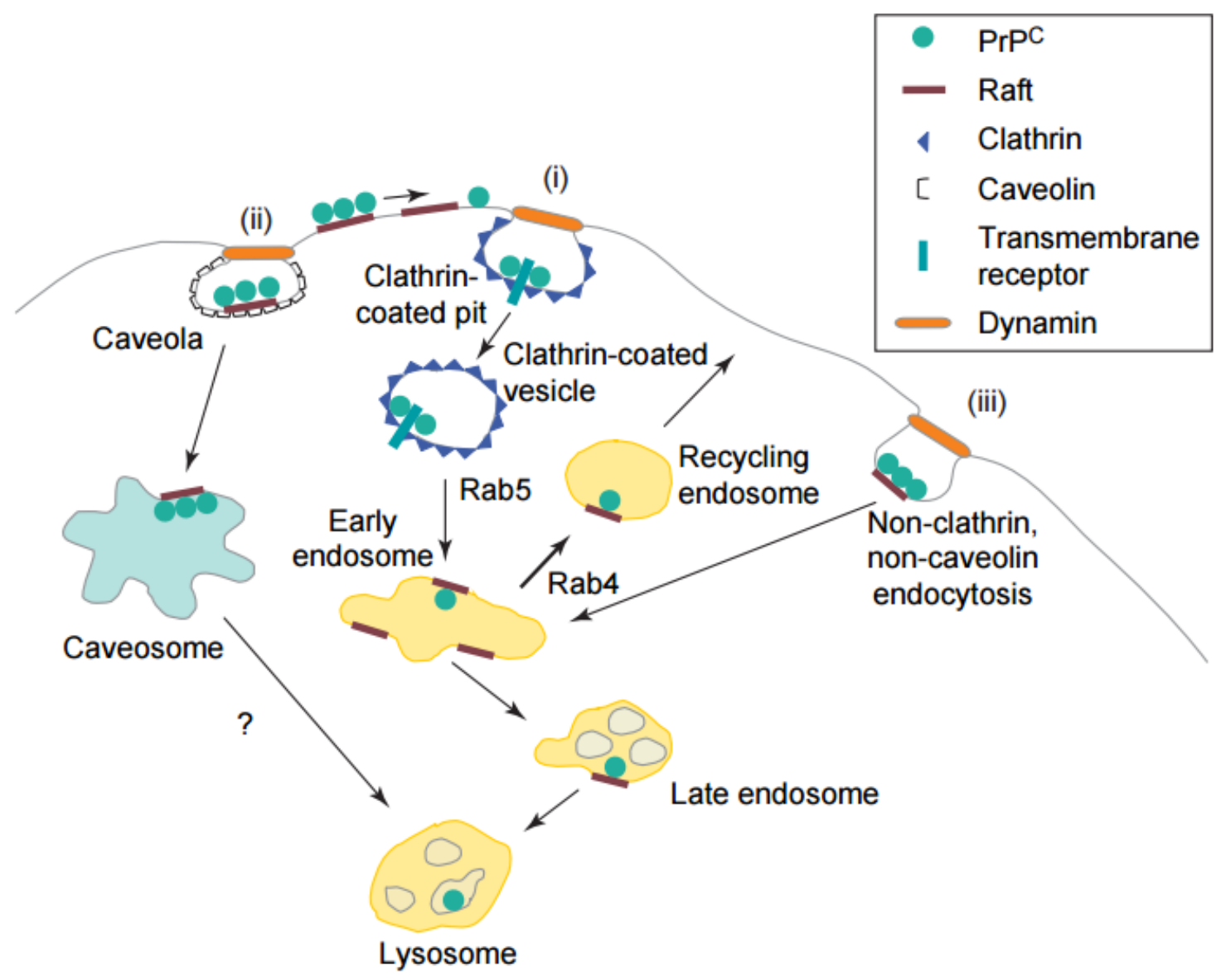

Figure 3: $\operatorname{PrP}^{\mathrm{C}}$ internalization Pathways. (i) A main pathway of $\operatorname{PrP}^{\mathrm{C}}$ internalization in neuronal cells appears to depend on clathrin-mediated endocytosis. (ii) Caveolin-associated endocytosis and trafficking have been implicated in $\operatorname{PrP}^{\mathrm{C}}$ internalization in Chinese hamster ovary and glial cells. Rab5-positive endosomes and Rab4 involving recycling endosomes have also been implicated in the $\operatorname{PrP}^{\mathrm{C}}$ endocytic transport. (iii) Finally, non-clathrin and noncaveolin but raft dependent endocytosis has been proposed to participate in the internalisation and conversion of prion protein. (adapted from (Campana et al., 2005))

It had been shown that the basic amino acid motif in the $\mathrm{N}$-terminal region of $\operatorname{PrP}^{\mathrm{C}}$ is required for its localization to clathrin-coated pits and the subsequent internalization of it (Lee et al., 2001a; Sunyach, 2003). These findings suggest that the $\mathrm{N}$-terminal region of $\operatorname{PrP}^{\mathrm{C}}$ may be binding to a transmembrane protein containing a localization signal for coated pits. 
Another putative mechanism of internalization in various cell models has been proposed, which states that $\operatorname{PrP}^{\mathrm{C}}$ clusters in caveolae or caveolae-like domains (Kaneko et al., 1997; Vey et al., 1996). Further, prion protein internalization mechanism involves lipid rafts. GPIanchored prion protein needs to translocate out from its lipid rafts into non-raft regions of the membrane to internalize through clathrin-coated pits. Indeed, Sunyach et al. confirmed that using primary cultures of neurons as well as neuroblastoma $\mathrm{N} 2 \mathrm{a}$ cells, $\operatorname{PrP}^{\mathrm{C}}$ translocates out of the lipid rafts (detergent-insoluble) into non-raft regions of the membrane, following which it enters clathrin-coated pits for endocytosis and cycles back to the cell surface via perinuclear sorting compartments (Sunyach, 2003).

Several proteins have been suggested to bind and act as endocytic partners for $\operatorname{PrP}^{\mathrm{C}}$ (Linden et al., 2008; Morris et al., 2006). For example, the NH2-KKRPKPGGW- amino acid residues of the $\mathrm{N}$-terminal domain of $\mathrm{PrP}^{\mathrm{C}}$ have been identified as a major heparin sulphate binding site of $\operatorname{PrP}^{\mathrm{C}}$ (Pan et al., 2002)(Warner et al., 2002). Recently, it has been shown that LRP1 binds to $\operatorname{PrP}^{\mathrm{C}}$ to facilitate its trafficking to the neuronal surface and that LRP1 associates with endogenous $\operatorname{PrP}^{\mathrm{C}}$ on the neuronal cell surface to internalize it (Parkyn et al., 2008). $\mathrm{Cu}^{2+}$ has also been demonstrated to draw $\operatorname{PrP}^{\mathrm{C}}$ out of its rafts prior to its endocytosis in SH-SY5Y cells and more recently it was shown that in the same cell model, LRP1 is required for $\mathrm{Cu}^{2+}$-dependent endocytosis of exogenous $\operatorname{PrP}^{\mathrm{C}}$ (Taylor and Hooper, 2007; Taylor et al., 2005).

\subsection{Conformational transition from $\operatorname{PrP}^{\mathrm{C}}$ to $\operatorname{PrP}^{\mathrm{Sc}}$}

It is widely accepted that the conformational transition of the native and predominantly $\alpha$-helical $\operatorname{PrP}^{\mathrm{C}}$ to the $\beta$-sheet containing pathogenic isoform $\mathrm{PrP}^{\mathrm{Sc}}$, results in the extracellular accumulation of $\mathrm{PrP}^{\mathrm{Sc}}$ aggregates. The exact mechanism for the conformational conversion is not yet known but several theories have been proposed. 
According to the widely accepted "protein only" hypothesis, two mechanisms have been proposed to explain the conformational conversion of $\operatorname{PrP}^{\mathrm{C}}$ into $\operatorname{PrP}^{\mathrm{Sc}}$ (Aguzzi and Calella, 2009). (i) The "template-directed refolding" hypothesis, which postulates an interaction between $\operatorname{PrP}^{\mathrm{Sc}}$ and endogenous $\operatorname{PrP}^{\mathrm{C}}$ to induce the conformational conversion (Figure 4A) (Prusiner, 1991); and (ii) a "seeded nucleation" hypothesis suggests that $\operatorname{PrP}^{\mathrm{Sc}}$ exists in equilibrium with $\operatorname{PrP}^{\mathrm{C}}$ (Figure 4B) (Jarrett and Lansbury, 1993). According to this "seeded nucleation" hypothesis, the infectious agent would consist of a highly ordered aggregate state of $\mathrm{PrP}^{\mathrm{Sc}}$ and it would be an essential property of infectivity. Monomeric $\mathrm{PrP}^{\mathrm{Sc}}$ might not exist in isolation, but in any case, would be harmless, while it might be prone to incorporation into nascent $\operatorname{PrP}^{\mathrm{Sc}}$ aggregates (Aguzzi and Calella, 2009).

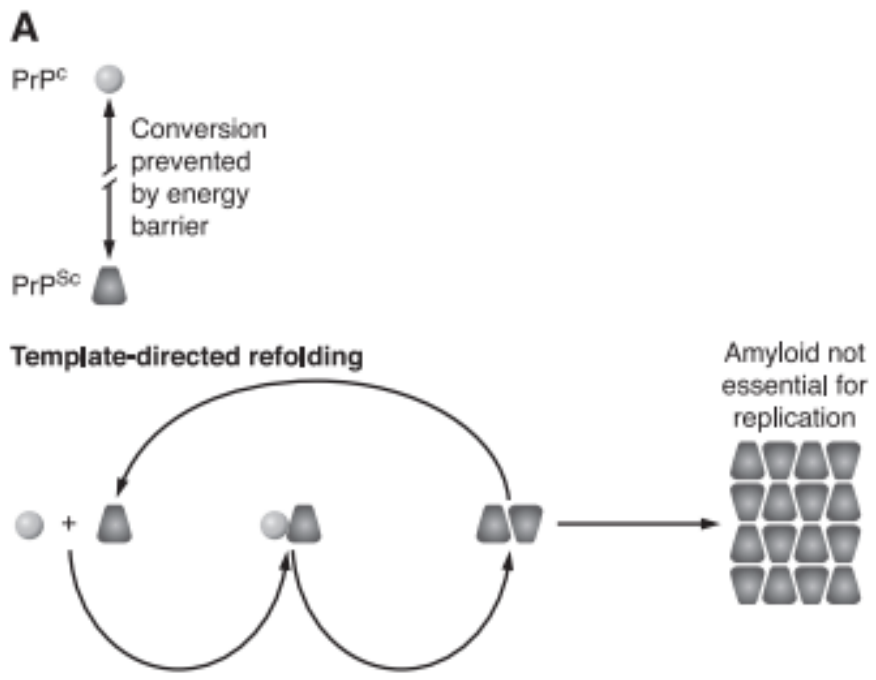




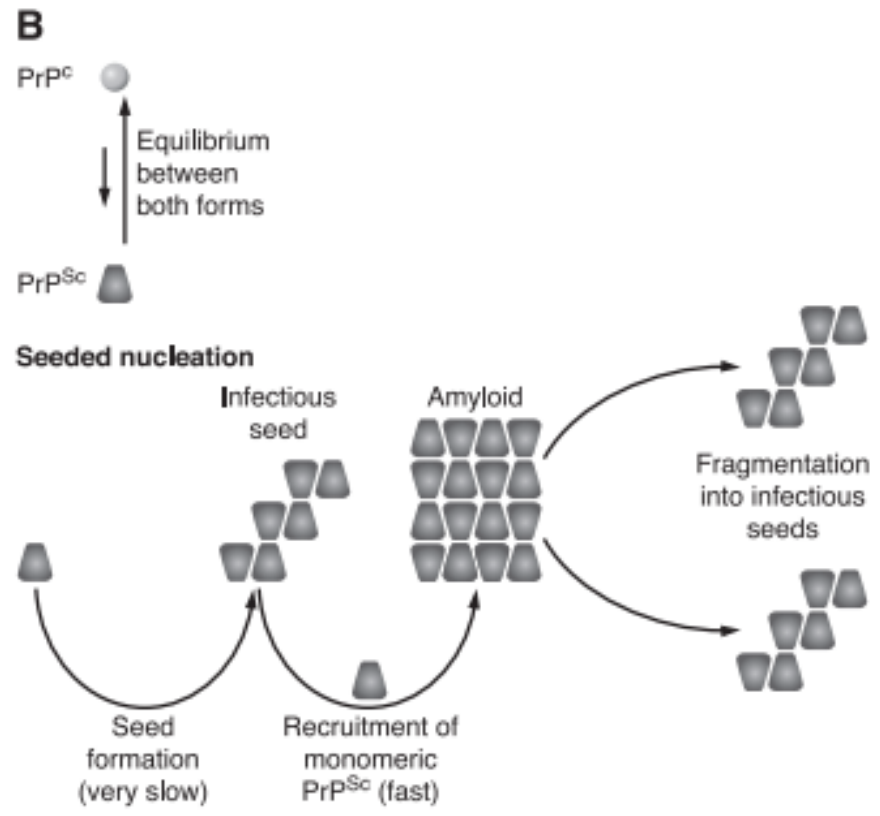

Figure 4: Models for the conformational conversion of $\operatorname{PrP}^{\mathrm{C}}$ into $\operatorname{PrP}^{\mathrm{Sc}}$. (A) the "template-directed refolding" hypothesis postulates an interaction between exogenously introduced $\operatorname{PrP}^{\mathrm{Sc}}$ and endogenous $\mathrm{PrP}^{\mathrm{C}}$, which is induced to transform itself into further PrPSc. A high-energy barrier may prevent spontaneous conversion of $\operatorname{PrP}^{\mathrm{C}}$ into $\operatorname{PrP}^{\mathrm{Sc}}$. (B) "seeded nucleation" hypothesis proposes that $\operatorname{PrP}^{\mathrm{C}}$ and $\mathrm{PrP}^{\mathrm{Sc}}$ are in a reversible thermodynamic equilibrium. Only if several monomeric $\operatorname{PrP}^{\mathrm{Sc}}$ molecules are mounted into a highly ordered seed, can further monomeric $\operatorname{PrP}^{\mathrm{Sc}}$ be recruited and eventually aggregate to amyloid. (adapted from (Aguzzi and Calella, 2009))

The conversion of $\operatorname{PrP}^{\mathrm{C}}$ to $\operatorname{PrP}^{\mathrm{Sc}}$ has been proposed to take place along numerous pathways (Figure 5) (Campana et al., 2005). 


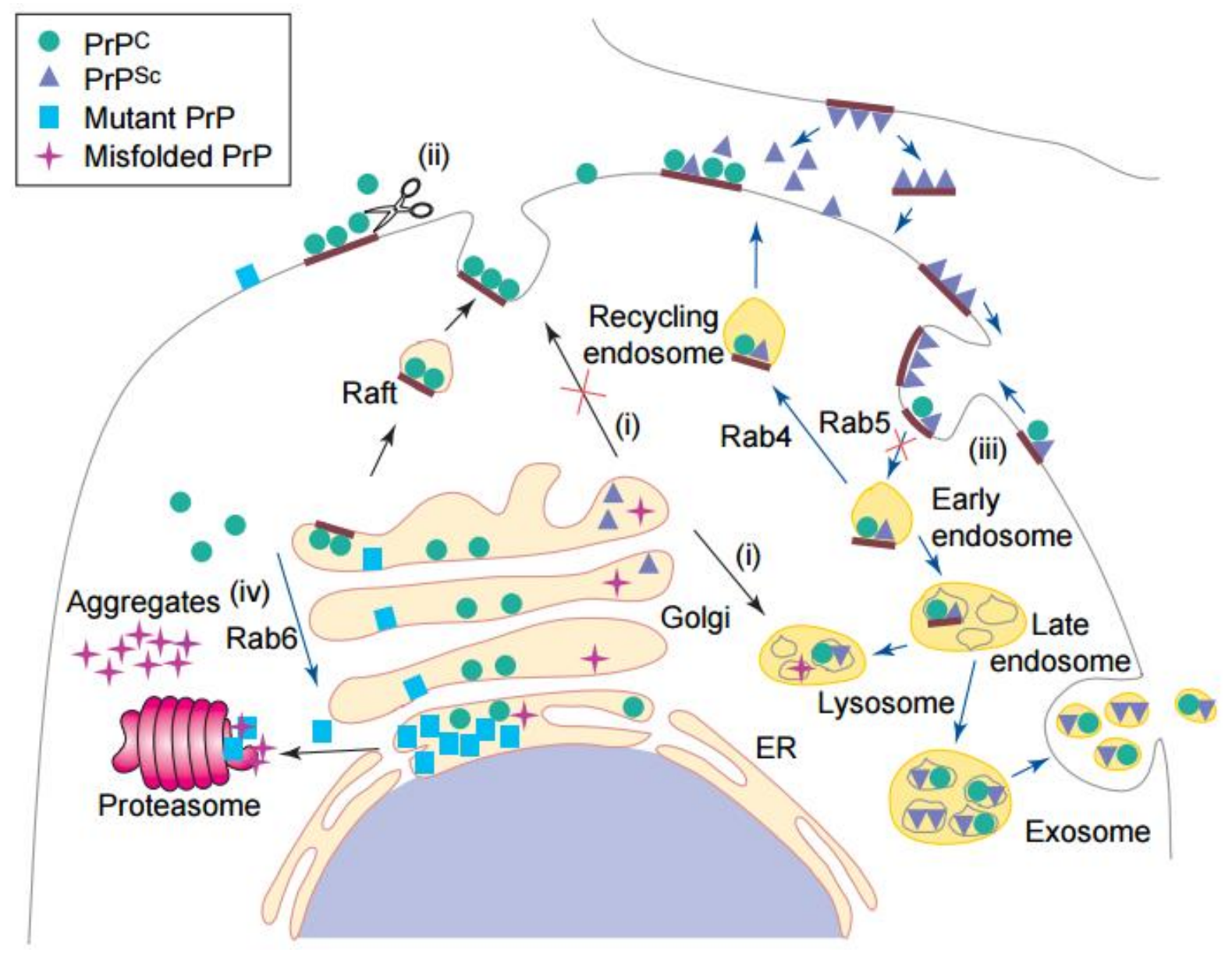

Figure 5: Possible pathways of $\operatorname{PrP}^{\mathrm{Sc}}$ formation. After its synthesis and ER quality control, $\mathrm{PrP}^{\mathrm{C}}$ is transported through the Golgi apparatus to the cell surface, where it associates with rafts and is internalized by clathrin- and/or caveolin dependent mechanisms. (i) Blocking transport of $\operatorname{PrP}^{\mathrm{C}}$ to the plasma membrane and rerouting it to lysosomes for degradation. (ii) Releasing nascent $\mathrm{PrP}^{\mathrm{C}}$ from the cell surface prevents the formation of $\mathrm{PrP}^{\mathrm{Sc}}$. (iii) A reduction in $\operatorname{PrP}^{\mathrm{C}}$ internalization also decreases $\mathrm{PrP}^{\mathrm{Sc}}$ formation. Both $\operatorname{PrP}$ isoforms are found in Rab5positive early endosomes, pass through late endosomes and are totally $\left(\operatorname{PrP}^{\mathrm{C}}\right)$ or partially $\left(\mathrm{PrP}^{\mathrm{Sc}}\right)$ degraded in acidic lysosomes. Moreover, part of the $\operatorname{PrP}^{\mathrm{C}}$ pool is recycled back to the plasma membrane in a Rab4-dependent pathway, and both $\operatorname{PrP}^{\mathrm{C}}$ and $\operatorname{PrP}^{\mathrm{Sc}}$ are found associated with exosomal membranes in the extracellular medium of infected cells. (iv) The ER has been postulated to have a role in prion conversion by amplifying $\mathrm{PrP}^{\mathrm{Sc}}$ formation after the Rab6a-dependent retrograde transport of $\operatorname{PrP}^{\mathrm{C}}$. (adapted from (Campana et al., 2005))

Among them, first, studies suggest that $\operatorname{PrP}^{\mathrm{C}}$ mutants, which are associated with familial forms of CJD, are retained by chaperones in the ER (Campana et al., 2006; Drisaldi et al., 2003), thereby indicating that, in inherited prion disease the conversion process could be occurring early in the biosynthesis of $\operatorname{PrP}^{\mathrm{C}}$. Second, in the conversion process, as studies have 
shown, direct surface contact is required for the transfer of infection in cell models of scrapie (Kanu et al., 2002). Third, when released from scrapie-infected cells, exosomes have been implicated to carry infection (Aguzzi and Lakkaraju, 2015; Fevrier et al., 2004) and fourth, in conversion of $\operatorname{PrP}^{\mathrm{C}}$ to $\operatorname{PrP}^{\mathrm{Sc}}$, endocytic pathway could be involved as per the evidences (Borchelt et al., 1992; Taraboulos et al., 1992). Furthermore, it is also possible that prions use lipid rafts to enter cells and to initiate and/or propagate the conversion of $\mathrm{PrP}^{\mathrm{C}}$ to $\operatorname{PrP}^{\mathrm{Sc}}$ (Campana et al., 2005). Up to date there is no consensus on whether all, or which of these routes would be primary means of cellular conversion of $\operatorname{PrP}^{\mathrm{C}}$ (Aguzzi and Lakkaraju, 2015).

\subsection{Functions of $\operatorname{PrP}^{C}$}

The exact cellular functions of $\mathrm{PrP}^{\mathrm{C}}$ are still unknown. However, in the last several years, various biological functions have been suggested, which includes copper metabolism, signal transduction, antioxidant activity, neurotransmitter metabolism, neurogenesis, immune cell activation, cell adhesion, and homeostasis of trace elements (Brown et al., 1997a, 1997b; Cashman et al., 1990; Graner et al., 2000; Kawahara et al., 2011; Lee et al., 1999; Mangé et al., 2002; Mouillet-Richard et al., 2000).

\subsubsection{PrP - metal relations}

The direct or indirect interactions of PrP with various transition metals has been implicated in both TSE and Alzheimer's, as being a contributing factor for triggering a neurodegenerative condition (Ayton et al., 2013; Rana et al., 2009; Solomon et al., 2012). Both in vivo and in vitro studies have demonstrated that $\operatorname{PrP}^{\mathrm{C}}$ binds divalent cations (La Mendola and Rizzarelli, 2014). Experimental and molecular dynamics studies on recombinant PrP and PrP-derived peptides have indicated the existence of a number of potential binding sites for divalent metal ions. The most encountered site is the $\mathrm{OR}$ of $\operatorname{PrP}^{\mathrm{C}}$ which can bind to 
copper, zinc, manganese, nickel and iron; among which copper shows the highest binding affinity to the OR region (Jackson et al., 2001b; Pandey et al., 2010; Russo et al., 2011; Singh et al., 2010; Stöckel et al., 1998). Majority of the earlier hypotheses about the normal cellular function of $\mathrm{PrP}^{\mathrm{C}}$, addressed the protein as a $\mathrm{Cu}^{2+}$-binding protein (Brown et al., 1997c). The structure and stability of the formed complexes between $\operatorname{PrP}$ and metals are highly dependent on pH and metal/ligand ratio (Miura et al., 2005; Di Natale et al., 2013; Viles et al., 1999). In the presence of sub-stoichiometric metal concentrations or acidic $\mathrm{pH}$, the imidazole nitrogen atoms are the only true effective donor atoms for both copper and zinc. Macro-chelates are formed, in which up to four histidines bind to a single metal ion. Two additional copper coordinating sites have also been identified at His-96 and His-111 in human $\operatorname{PrP}^{\mathrm{C}}$. At neutral or basic $\mathrm{pH}$ and in the presence of concentrations of copper (at least equimolar with respect to the peptide), all histidines can behave as independent coordination sites and $\operatorname{PrP}^{\mathrm{C}}$ can bind up to six $\mathrm{Cu}^{2+}$ ions in vivo (Brown et al., 1997d) as reviewed recently (Kozlowski et al., 2013). In this case, the amide nitrogen atoms come predominantly from the neighboring glycines. $\mathrm{Zn}^{2+}$ is not able to displace amide protons and thus forms less stable complex in respect to $\mathrm{Cu}^{2+}$.

Although $\operatorname{PrP}^{\mathrm{C}}$ has an apparent affinity toward several transition metals, it is much less clear that which of these interactions are attributable to a physiological activity of $\operatorname{PrP}^{\mathrm{C}}$. This has prompted a number of in vitro and in vivo studies to investigate this relation (Li et al., 2004; Rana et al., 2009; Waggoner et al., 2000). Transition metal-PrP ${ }^{\mathrm{C}}$ interactions might have an impact on $\operatorname{PrP}^{\mathrm{C}}$ biology by internalization and shedding of $\operatorname{PrP}^{\mathrm{C}}$ that were reported to occur in response to transition metal stimuli (Brown and Harris, 2003; Parkin et al., 2004; Pauly and Harris, 1998).

$\mathrm{Cu}^{2+}$ and $\mathrm{Zn}^{2+}$ induced rapid endocytosis of $\mathrm{PrP}^{\mathrm{C}}$ was a major breakthrough discovery, thus linking metal binding to a physiological response (Pauly and Harris, 1998; Watt and Hooper, 2003). Accordingly, $\operatorname{PrP}^{\mathrm{C}}$ is thought to possess a $\mathrm{Cu}^{2+}$-dependent enzyme function, 
specifically to participate in $\mathrm{Cu}^{2+}$ homeostasis or function as an antioxidant. The prion protein shows evidence of $\mathrm{Zn}^{2+}$ binding in solution, with an affinity that is two to three orders of magnitude lower than that of $\mathrm{Cu}^{2+}$ (Pan et al., 1992). It has been shown that concomitant with conformational change to $\operatorname{PrP}^{\mathrm{Sc}}$ form, neuronal cells undergo imbalance in $\mathrm{Zn}^{2+}$ homeostasis (Watt and Hooper, 2003). Linking PrP- $\mathrm{Zn}^{2+}$ interaction with endocytosis (Watt et al., 2012), a $\operatorname{PrP}^{\mathrm{C}} \rightarrow \operatorname{PrP}^{\mathrm{Sc}}$ conversion would be expected to alter the level of $\mathrm{Zn}^{2+}$ in the infected brain tissues. However, there are contrasting reports in this respect.

The report of other metal ions, especially $\mathrm{Mn}^{2+}$ interaction with prion protein came from the studies of Brown et al. (Brown et al., 2000). In their work, they demonstrated that $\mathrm{Mn}^{2+}$ can actually replace $\mathrm{Cu}^{2+}$ in $\mathrm{PrP}^{\mathrm{C}}$ in its full length form and display the same SOD activity as the $\mathrm{Cu}^{2+}$-bound form of the protein. Further, when $\mathrm{Mn}^{2+}$ bound to $\mathrm{PrP}^{\mathrm{C}}$ rendered the protein protease resistant and assumed structures similar to those of $\mathrm{PrP}^{\mathrm{Sc}}$, phenomenon shown for the first time. It has also been observed that the replacement of bound $\mathrm{Cu}^{2+}$ by $\mathrm{Mn}^{2+}$ significantly increases the $\beta$-sheet content of $\operatorname{PrP}^{\mathrm{C}}$, thereby leading to fibril formation (Brown et al., 2000). This has been proposed to be principally due to differences in the interactions of $\mathrm{Mn}^{2+}$ and $\mathrm{Cu}^{2+}$ with PrP. Some studies demonstrated that cellular prion protein serves as a protective agent against $\mathrm{Mn}^{2+}$-induced oxidative stress (Choi et al., 2007).

$\mathrm{Fe}^{2+}$ regulation has been shown to be disturbed in scrapie-infected cells, leading to higher $\mathrm{Fe}^{2+}$ levels which cause increased formation of reactive oxygen species and cell death. These findings suggest that, infection by scrapie is linked to the changes in $\mathrm{Fe}^{2+}$ homeostasis (Fernaeus et al., 2005; Kim et al., 2000). Significant evidence also exists for the $\mathrm{Fe}^{2+}$-binding property of $\operatorname{PrP}^{\mathrm{C}}$ (Fernaeus et al., 2005). Scrapie infected mouse-brain homogenates as well as CJD infected human brain homogenates show four to six-fold more $\mathrm{Fe}^{2+}$ as compared to age-matched controls. The binding affinities and dissociation constants of $\mathrm{Fe}^{2+}$ to prion protein are yet to be established. Other divalent cations such as $\mathrm{Ni}^{2+}, \mathrm{Cd}^{2+}$ and 
$\mathrm{Ca}^{2+}$ have also been known to show weak binding to prion protein (Jackson et al., 2001b), although the effects of such binding to the physiological functions of $\operatorname{PrP}^{\mathrm{C}}$ or to the pathogenesis of prion diseases are yet to be investigated in detail.

The interaction of the cellular prion protein with different divalent metal cations is found to have several common features: 1) Involvement in oxidative stress mechanisms 2) Common binding sites in the octarepeat region 3) Alteration in the metal levels inside the cells 4) Linkage between $\operatorname{PrP}^{\mathrm{C}}$ expression and extracellular metal concentrations 5) Conformational effects, such as conversion to protease and detergent resistant forms 6) Altered interactions with $\mathrm{PrP}^{\mathrm{Sc}}$ infected forms.

\subsubsection{Role of divalent cations in the pathogenesis of prion diseases}

Prion diseases caused by the accumulation of $\operatorname{PrP}^{\mathrm{Sc}}$ isoform mainly affect the brain regions that co-ordinate motor function including the cerebellum, thalamus, cerebral cortex, and the basal ganglia. Most in vivo studies of prion disease have also shown that there is an interrelationship between $\mathrm{PrP}^{\mathrm{Sc}}$ formation and altered levels of several divalent metal cations including $\mathrm{Cu}^{2+}, \mathrm{Zn}^{2+}, \mathrm{Mn}^{2+}$ and $\mathrm{Fe}^{2+}$, thereby suggesting a possible role for these metals in the pathogenesis of prion diseases.

$\mathrm{Cu}^{2+}$ can induce conversion of $\mathrm{PrP}^{\mathrm{C}}$ to a PK-resistant species, having a conformation distinct from $\operatorname{PrP}^{\mathrm{Sc}}$ reported by Qin et al. and Quaglio et al. (Qin et al., 2000; Quaglio et al., 2001). Furthermore, from the protein renaturation experiments on $\mathrm{GdnHCl}$-denatured $\mathrm{PrP}^{\mathrm{Sc}}$, it was found that PK-resistant infectious prions regeneration was enhanced by the presence of $\mathrm{Cu}^{2+}($ McKenzie et al., 1998). Also, acidic-pH mediated conversion of ovine PrP to a PKresistant $\beta$-sheet rich structure was shown to be modulated by $\mathrm{Cu}^{2+}$ (Liu et al., 2008). In a subsequent paper, Wong et al. (Wong et al., 2001a) demonstrated that not only $\mathrm{Cu}^{2+}$ but other metal ions such as $\mathrm{Mn}^{2+}$ and $\mathrm{Zn}^{2+}$ also display pivotal role in prion pathogenesis. 
$\mathrm{PrP}^{\mathrm{Sc}}$ infected mice showed a higher $\mathrm{Mn}^{2+}$ content in brain, muscles and blood compared to normal mice (Thackray et al., 2002). It has been known that in the presence of $\mathrm{Mn}^{2+}$, recombinant $\operatorname{PrP}^{\mathrm{C}}$ converted into a proteinase-K-resistant non-pathogenic, abnormal isoforms of $\operatorname{PrP}^{\mathrm{Sc}}$. Basu and coworkers reported that $\operatorname{PrP}^{\mathrm{C}}$ on the surface of human neuroblastoma cells binds to an inorganic source of redox $\mathrm{Fe}^{2+}$ and induces conversion of $\operatorname{PrP}^{\mathrm{C}}$ into a $\mathrm{PrP}^{\mathrm{Sc}}$-like form (Basu et al., 2007). This isoform shows similar characteristics of the scrapie form such as typical proteinase- $\mathrm{K}$ resistance and detergent insolubility. These results indicate a strong correlation between prion disease pathogenesis and $\mathrm{Fe}^{2+}$ levels, which could be linked to the conversion of $\operatorname{PrP}^{\mathrm{C}}$ into a $\operatorname{PrP}^{\mathrm{Sc}}$-like form. However, the exact mechanism of such an interaction remains unknown.

\subsubsection{PrP functions as antioxidant}

Free transition metal ions are especially highly effective in generating reactive oxygen species (ROS) that can induce lipid peroxidation and protein oxidation, leading to cellular damage (Berlett and Stadtman, 1997; Lee et al., 2012). Many reports showed a protective role of $\operatorname{PrP}^{\mathrm{C}}$ against cellular stresses, especially against oxidative damage, which is perhaps one of the most widely accepted functions of $\operatorname{PrP}^{\mathrm{C}}$ (Brown et al., 1997b, 1997d; Holada et al., 2002; Klamt et al., 2001; Rachidi et al., 2003a; White et al., 1999; Wong et al., 2001b). Remarkably, the loss of antioxidant defense was suggested to play a major role in scrapie-infected cells and prion diseases (Arlt et al., 2002; Guentchev et al., 2000, 2002; Milhavet et al., 2000;

Wong et al., 2001c). Regarding the mechanisms of these protective effects of $\operatorname{PrP}^{\mathrm{C}}$, it was shown that cultured cells derived from Prnp $^{-/-}$mice were more sensitive to oxidative damage and exhibited reduced superoxide dismutase (SOD) activity when compared with WT (Brown et al., 1997b). Furthermore, recombinant $\mathrm{PrP}^{\mathrm{C}}$ refolded in the presence of $\mathrm{Cu}^{2+}$ was reported to have SOD activity (Brown et al., 1999) although other authors found neither decreased 
SOD activity in $\operatorname{Prnp}^{-/-}$mice nor SOD activity with recombinant $\operatorname{PrP}^{\mathrm{C}}$ (Jones et al., 2005; Sakudo et al., 2003; Waggoner et al., 2000). In addition, experiments using genetically modified mice, as well as cross between $\operatorname{PrP}^{\mathrm{C}}$ overexpressing and SOD-deficient mice argue against such a role for $\mathrm{PrP}^{\mathrm{C}}$ in vivo (Hutter et al., 2003).

Alternatively, it is possible that the binding of $\mathrm{Cu}^{2+}$ or $\mathrm{Zn}^{2+}$ to $\operatorname{PrP}^{\mathrm{C}}$ that induces its endocytosis, is a signal for triggering antioxidative defense (Brown and Besinger, 1998; Brown et al., 1997b; Vassallo and Herms, 2003) even though non-oxidative mechanisms are considered (Haigh and Brown, 2006). Nevertheless, the mechanism is not clear. A protective effect for $\operatorname{PrP}^{\mathrm{C}}$ or its fragments in metal-induced toxicity has been reported in few studies by using various model systems (Choi et al., 2007; Haigh and Brown, 2006; Rachidi et al., 2009).

The aim of the presented studies in the current thesis is to examine the role of PrP in condition of metal stress induced by various concentrations of $\mathrm{Cu}^{2+}, \mathrm{Zn}^{2+}, \mathrm{Mn}^{2+}$, and $\mathrm{Co}^{2+}$, using the hippocampus-derived mouse neuronal cells, $\mathrm{Zpl}\left(\operatorname{Prnp}^{-/-}\right)$and $\mathrm{ZW}\left(\operatorname{Prnp}^{+/+}\right)$, and the SH-SY5Y human neuroblastoma cells as model systems. 


\section{Main objectives of the thesis}

Prion protein has been reported to have a protective role against certain transition metals induced toxicities in cell culture model systems (Choi et al., 2007; Haigh and Brown, 2006; Rachidi et al., 2009), however, the data are not absolutely univocal in the different systems used. The hippocampus-derived, Prnp $^{-{ }^{-}}$ablated, Zpl 2-1 cells have been shown to be more vulnerable to serum deprivation and oxidative damage induced by $\mathrm{H}_{2} \mathrm{O}_{2}$ than its PrPexpressing counterpart, ZW cells, derived from the wild type mice (Kim et al., 2004; Oh et al., 2008, 2012), furthermore reintroduction of PrP restored the viability of Zpl cells in this context. Thus, this model system seems to be relevant for assessing the effect of $\operatorname{PrP}^{\mathrm{C}}$ on metal-induced toxicity as well. The main objective of my Ph.D. thesis was to test whether $\operatorname{PrP}$ has any general protective role against metal-induced toxicity in this system, using four different metals. The specific aims of my Ph.D. thesis were to answer the following questions:

1) Does the PrP lacking $\mathrm{Zpl} 2-1$ cells are more susceptible to $\mathrm{Cu}^{2+}, \mathrm{Zn}^{2+}, \mathrm{Mn}^{2+}$ and $\mathrm{Co}^{2+}$ induced toxicities than the control ZW cell line?

2) Does PrP expression generated in Zpl cells confer any elevated resistance to the cells against metal-induced toxicity?

3) Would the PrP expression generated SH-SY5Y cells, as a different model system, confer increased resistance to the cells against $\mathrm{Cu}^{2+}, \mathrm{Zn}^{2+}, \mathrm{Mn}^{2+}$ and $\mathrm{Co}^{2+}$ metalinduced toxicities?

To address the above questions we chose methods that report on the general health of the cells, rather than looking at a specific pathway involved: such as alamarBlue viability assay, propidium iodide-based dye exclusion assay and morphological examination of the cells. Also, we extended the studies to four different metals, which were applied in various concentrations: $\mathrm{Cu}^{2+}, \mathrm{Zn}^{2+}, \mathrm{Mn}^{2+}$ and $\mathrm{Co}^{2+}$. 


\section{Materials and Methods}

\subsection{Reagents and antibodies}

All chemicals used were from Sigma-Aldrich unless stated otherwise.

AlamarBlue cell viability reagent was from Life Technologies (DAL1100). Protease Inhibitor Cocktail and Phenylmethanesulfonyl fluoride (PMSF) were from Sigma-Aldrich (P2714 and P7626, respectively). PNGase F was from New England Biolabs (P0704), TurboFect Transfection Reagent was from Thermo Scientific (R0531), RC DC Protein Assay kit was from Bio-Rad (500-0121), Copper(II) sulfate pentahydrate, Zinc (II) sulfate heptahydrate and cobalt chloride (II) hexahydrate were from Molar Chemicals $\mathrm{Kft}, \mathrm{MnCl}_{2}$ was from SigmaAldrich (M8054).

Anti-Prion Protein Monoclonal Antibody was from Spi-Bio (Clone SAF 32; A03202), Anti-Mouse IgG (Fab specific)-Peroxidase antibody and $\beta$-Actin antibody were from SigmaAldrich (A3682 and A5316, respectively), Alexa Fluor 568 Anti-Mouse IgG (H+L) was from Life Technologies (A11004).

All cell culture reagents were from Life Technologies/Gibco; high glucose Dulbecco's Modified Eagle's medium (DMEM) (41966), DMEM/F-12 (31331), Fetal Bovine Serum (FBS) (10500), Penicillin Streptomycin (15070), GlutaMAX (35050).

\subsection{Cell culturing, transfection and generation of stable cell lines}

Neuronal cell lines ZW 13-2 and Zpl 2-1, were established from the hippocampus of ICR $\left(\right.$ Prnp $\left.^{+/+}\right)$and Zurich I Prnp ${ }^{-/-}$mice, respectively, by Kim and coworkers [63]. Zpl 21and SH-SY5Y cell lines stably expressing mouse PrP and GFP (Zpl 2-1-PrP and SH-SY5Y$\mathrm{PrP}$ ) or GFP and puromycin resistance gene (Zpl 2-1-vector and SH-SY5Y-vector) were produced as follows. Briefly, $1 \times 10^{5}$ cells/well were seeded on a 6-well plate and transfected 
using TurboFect transfection reagent, according to manufacturer's protocol. The following plasmids were introduced to the cells: A Sleeping Beauty plasmid (pSB), containing two expression cassettes between transposon arms, one coding the Enhanced Green Fluorescent Protein (EGFP) driven by CMV promoter, and the other coding either wild type mouse prion protein $(\mathrm{PrP})$ or a puromycin resistance gene driven by a CAG promoter. The second plasmid (SBx100) was coding for an active transposase enzyme to catalyze the linked integration of the two expression cassettes from the pSB plasmid. GFP positive cells were sorted 3 and 14 days post-transfection using a FACS Aria fluorescence-activated cell sorter. The cells were amplified and frost at about 35 post-transfection. The expression and localization of GFP and PrP were confirmed by western blotting and immunocytochemistry. ZW and Zpl cells were maintained in DMEM supplemented with $10 \%$ FBS, $1 \%$ GlutaMAX and $1 \%$ penicillinstreptomycin at $37{ }^{\circ} \mathrm{C}$ under $5 \% \mathrm{CO}_{2}$. SH-SY5Y cells were maintained in DMEM/F-12 supplemented with $10 \%$ FBS, $1 \%$ GlutaMAX and $1 \%$ penicillin-streptomycin at $37{ }^{\circ} \mathrm{C}$ under $5 \% \mathrm{CO}_{2}$

\subsection{Western blot analysis}

One $10 \mathrm{~cm}$ Petri dish of confluent cultured cells were washed twice with ice-cold phosphate buffered saline (PBS) and scraped in a $1 \mathrm{ml}$ volume of PBS. Cells were pelleted by centrifugation at $500 \times \mathrm{g}$ and $4{ }^{\circ} \mathrm{C}$ for $5 \mathrm{~min}$. The supernatant was removed, and the pelleted cells were resuspended and lysed in cold lysis buffer (50 mM Tris-HCl pH 7.4, 1 mM EDTA, $150 \mathrm{mM} \mathrm{NaCl}, 1 \%$ Triton X-100) supplemented with $1 \mathrm{mM}$ phenylmethyl sulfonyl fluoride and protease inhibitor cocktail, and solubilization for $30 \mathrm{~min}$ on ice. Lysed cells were centrifuged at $15000 \times \mathrm{g}$ and $4{ }^{\circ} \mathrm{C}$ for $10 \mathrm{~min}$ to pellet and remove insoluble materials. Protein concentration of the soluble fraction was determined using RC-DC Protein Assay. For studies involving PNGase F digestion, each sample was treated with PNGase F as directed by the 
manufacturer. Briefly, each sample of $20 \mu \mathrm{g}$ protein was denatured at $100{ }^{\circ} \mathrm{C}$ for 10 minutes and incubated with and without of 1,500 units of PNGase F at $37^{\circ} \mathrm{C}$ for 2 hours. Samples were then analyzed by Western blot as follows. Equal amounts of total proteins, typically 10 $\mu \mathrm{g}$ were loaded on $12 \%$ polyacrylamide gels, separated by SDS-PAGE and transferred to methanol-activated Hybond-P polyvinylidene difluoride membrane (Millipore). The membrane was blocked by 5\% nonfat dry milk in PBS containing 0.05\% Tween 20 (PBST) for $1 \mathrm{~h}$ at room temperature followed by an overnight incubation with primary antibody against $\operatorname{PrP}(1: 3000)$, or $\beta$-actin $(1: 10,000)$. Blots were then incubated with horseradish peroxidase conjugated secondary antibody. The reactive protein bands were visualized on Xray films by Chemiluminescent substrate (Millipore) and were subsequently quantified by densitometry analysis of the gray-scale images of the scanned films using the ImageJ software.

\subsection{Immunocytochemistry}

Immunocytochemistry was used to determine the expression of $\mathrm{PrP}$ in the neuronal cell lines used. Cells were plated at $\sim 0.5 \times 10^{5}$ cells $/ \mathrm{ml}$ onto 8 -well chamber microscope slides (Nunc, Lab-Tek II). After $24 \mathrm{~h}$ of seeding, cells were washed with PBS and were fixed with fresh $4 \%$ paraformaldehyde (PFA) for 10 minutes at room temperature. PFA was removed by washing the cells with PBS. Samples were blocked by adding blocking solution (1\% BSA in PBS) for $45 \mathrm{~min}$ at room temperature, and were incubated with anti PrP (SAF-32) primary antibody at 1:250 dilution in blocking solution, overnight at $4{ }^{\circ} \mathrm{C}$. From each cell line one well was kept in blocking solution without applying the primary antibody, to serve as controls for estimating the background signal coming from unspecific binding of the secondary antibody. Next day cells were washed with blocking solution to remove primary antibody, followed by incubation with an anti-mouse Alexa Fluor 568 conjugated secondary antibody 
used at 1:300 dilution in blocking solution for $1 \mathrm{~h}$ at $37^{\circ} \mathrm{C}$. Unbound antibodies were washed by PBS and cells were incubated in $100 \mathrm{ng} / \mathrm{ml}$ 4',6-diamidino-2 phenylindole $\mathrm{HCl}$ (DAPI) for 5 min to stain DNA. DAPI was washed out by PBS and cells were imaged in PBS by using a confocal laser scanning microscope Fluoview FV1000 (Olympus Life Science Europa GmbH, Hamburg, Germany). Microscope configuration was as follows: UPLSAPO 60X (oil, NA:1.35) objective, zooming factor of either 4 or 1 , sampling speed $4 \mu \mathrm{s} /$ pixel, line averaging 2X, scanning mode sequential, unidirectional, excitation $405 \mathrm{~nm}$ (DAPI detection) and 543 nm (with Alexa568 red fluorescence detection). Counting of the PrP positive cells of the transformant $\mathrm{Zpl} 2-1-\mathrm{PrP}$ and $\mathrm{Zpl}$ 2-1-vector cells from the microscopy pictures was performed using five pictures recorded with $60 \mathrm{X}$ objective, no zooming, which equaled to populations of at least 250 cells.

\subsection{Metal ion treatment of cells}

When cells reached the desired confluency for a specific assay the media on top of the cells was supplemented with the indicated concentrations of either $\mathrm{CuSO}_{4}, \mathrm{ZnSO}_{4}, \mathrm{CoCl}_{2}$, or $\mathrm{MnCl}_{2} \cdot \mathrm{CuSO}_{4}$ in all cases was administered as a 1:4 mol/mol ratio with glycine $\left(\mathrm{Cu}^{2+}\right.$-Gly), which was pre-mixed fresh before the treatment. There was no any observable color change of the metal stock solution or metal supplemented media during the metal ion treatments, which would be indicative of a higher oxidation state of either cobalt or manganese. Treatments with metals were performed for $24 \mathrm{~h}$ duration before starting the assays.

\subsection{Cell viability assays and cell morphology}

Cell viability was determined by using alamarBlue cell viability reagent and a microplate reader Fluoroskan Ascent FL Microplate Fluorometer and Luminometer (Thermo Scientific). Briefly, cells were seeded into 96-well flat-bottomed plates to reach $40 \%$ 
confluency by $24 \mathrm{~h}$. The next day, the cells were either untreated (control) or treated with designated concentrations of $\mathrm{Cu}^{2+}, \mathrm{Zn}^{2+}, \mathrm{Mn}^{2+}$ or $\mathrm{Co}^{2+}$, respectively, for $24 \mathrm{~h}$. The cell proliferation assay was performed according to the manufacturer's instructions and fluorescence was measured by the microplate reader. At the indicated concentrations of the metal ions, morphological changes of the cells were also examined by using an Olympus CellR microscope and a 10X objective.

\subsection{Cell-death assays}

Cell-death was measured by propidium iodide (PI) exclusion assay. Briefly, cells were seeded into 6-well flat-bottomed plates to reach $40 \%$ confluency by $24 \mathrm{~h}$. The next day, cells were either untreated (control) or treated with designated concentrations of $\mathrm{Cu}^{2+}, \mathrm{Zn}^{2+}, \mathrm{Mn}^{2+}$ or $\mathrm{Co}^{2+}$, respectively, for $24 \mathrm{~h}$. Treated and untreated cells were collected, including dead floating cells in the medium, and were washed twice in PBS before re-suspension in $2 \mu \mathrm{g} / \mathrm{mL}$ PI. Percentage of dead cells up-taking PI was measured by flow cytometry (BD FACSCalibur Flow Cytometer, BD Biosciences).

\subsection{Statistical analysis}

Statistical analysis was performed on data originating from $\mathrm{N}=3$ to 5 independent experiments using Sigmaplot 12.5 software. The data are represented as the means \pm standard deviation (S.D). For comparison between two samples, a two-tailed Student's t-test was performed and values of $\mathrm{p}<0.05, \mathrm{p}<0.01$ and $\mathrm{p}<0.001$ were taken as being statistically significant. 


\section{Results}

The prion protein's role in a particular cellular process, including those that are concerned with metal-PrP interrelations in ex-vivo and in-vivo systems are generally studied by either genetically ablating (Büeler et al., 1992; Haigh and Brown, 2006; Kim et al., 2005; Kuwahara et al., 1999; Rossi et al., 2001; Sakaguchi et al., 1996) or siRNA silencing (Loubet et al., 2012) the expression of the prion protein. In this respect, cells that are generated from $\mathrm{Prnp}^{-/-}$mice are especially valuable. While some $\mathrm{Prnp}^{-/-}$cells are generated from mice with the ectopic expression of Doppel in the CNS (Kim et al., 2005; Kuwahara et al., 1999), Kim and coworkers (Kim et al., 2005) have established a series of cell lines , derived from primary neuronal cells of Zürich I Prnp ${ }^{-/}$(Zür I) mice (termed Zpl cells) and wild-type cell lines from ICR Prnp $^{+/+}$strain, which is the strain of origin of the Zür I mice (termed ZW cells) that do not express the Dpl gene. The fact that expression of Dpl in the absence of PrP expression in vivo can cause neuropathological and clinical changes, certainly affects the usefulness of a cell line that is $\mathrm{PrP}^{-/-}$and $\mathrm{Dpl}^{+/+}$in studying the role of PrP in cellular physiology, which is not the case for the Zpl cell line. From these series of Zpl and ZW mouse hippocampal neuronal cell lines, here we used the Zpl 2-1(Prnp $\left.{ }^{-/}\right)$and ZW 13-2 $\left(\right.$Prnp $\left.^{+/+}\right)$lines that have previously been fully characterized (Kim et al., 2005). Using these two cell lines we wanted to investigate whether the presence of PrP confers any general protection to the cells during transition metal stress.

\section{1 $\mathrm{ZW} 13-2$ cells are significantly more resistant to $\mathrm{Cu}^{2+}, \mathrm{Zn}^{2+}$, $\mathrm{Mn}^{2+}$ and $\mathrm{Co}^{2+}$ induced toxicities than $\mathrm{Zpl} 2-1$ cells}


Before starting the studies on ZW 13-2 and Zpl 2-1 cells, we have verified the expression levels of the prion protein in the cell cultures maintained in our laboratory using immunoblotting and immunocytochemical analyses (Figure 6 and 7). The glycosylation of the prion protein is variable, resulting in un-, mono-, or diglycosylated forms, depending on the number of glycosylation sites occupied with oligosaccharide chains. The glycosylation of the PrP in our samples was verified by treatment with the amidase Peptide -N-Glycosidase F (PNGase F), which accordingly reduced the relative molecular mass of the protein, consistent with the removal of asparagine-linked glycans. ZW 13-2 cells have a high level of $\operatorname{PrP}^{\mathrm{C}}$ expression with proper $\mathrm{N}$-glycosylation, which is confirmed by both untreated and PNGase treated samples (lanes 1 and 2, Figure 6). Contrary, Zpl 2-1 cells are a knockout cell line with no expression of $\operatorname{PrP}^{\mathrm{C}}$; accordingly, we have not found any detectable band for PrP on the immunoblot (lanes 3 and 4, Figure 6).

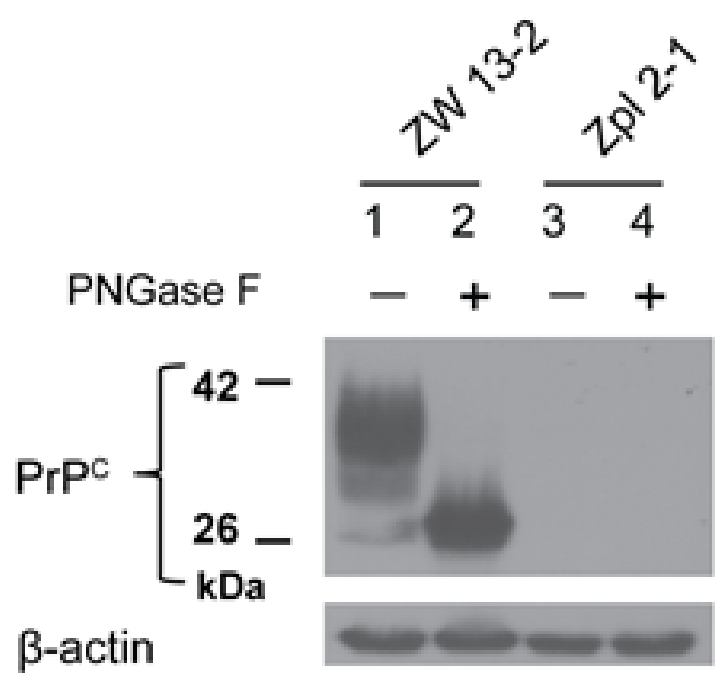

Figure 6: Immunoblotting performed to verify expression levels of $\operatorname{PrP}$ in the $\mathrm{ZW}$ 13-2 and Zpl 2-1 cell lines. Western blot of total cell lysates from wild type hippocampal neuronal cell line of ICR mice (ZW 13-2) and Prnp-/- hippocampal neuronal cell line of Zürich I mice (Zpl 2-1). Cell lysates were incubated either in the absence (lane 1 and lane 3 ) or in the presence of PNGase F (lane 2 and lane 4). Western blot analysis of PrP was carried out with monoclonal PrP antibody SAF 32. $\beta$-actin was used to confirm equal loading of proteins. 
Expression and localization of the prion protein in the two cell lines was further tested by immunocytochemical analysis (Figure 7). For cell imaging, confocal laser scanning microscope Olympus Fluoview FV1000 was used. Microscope configuration such as laser intensity settings and two channel image-acquisition settings I had optimized during my Ph.D. while working on HeLa cells (Molnár et al., 2013)., and have used here similarly. The bright red immunofluorescence-staining pattern in the ZW 13-2 cells revealed that the prion protein was distributed on the surface of the cells, whereas no immunoreactivity was detected in the Zpl 2-1 cells.

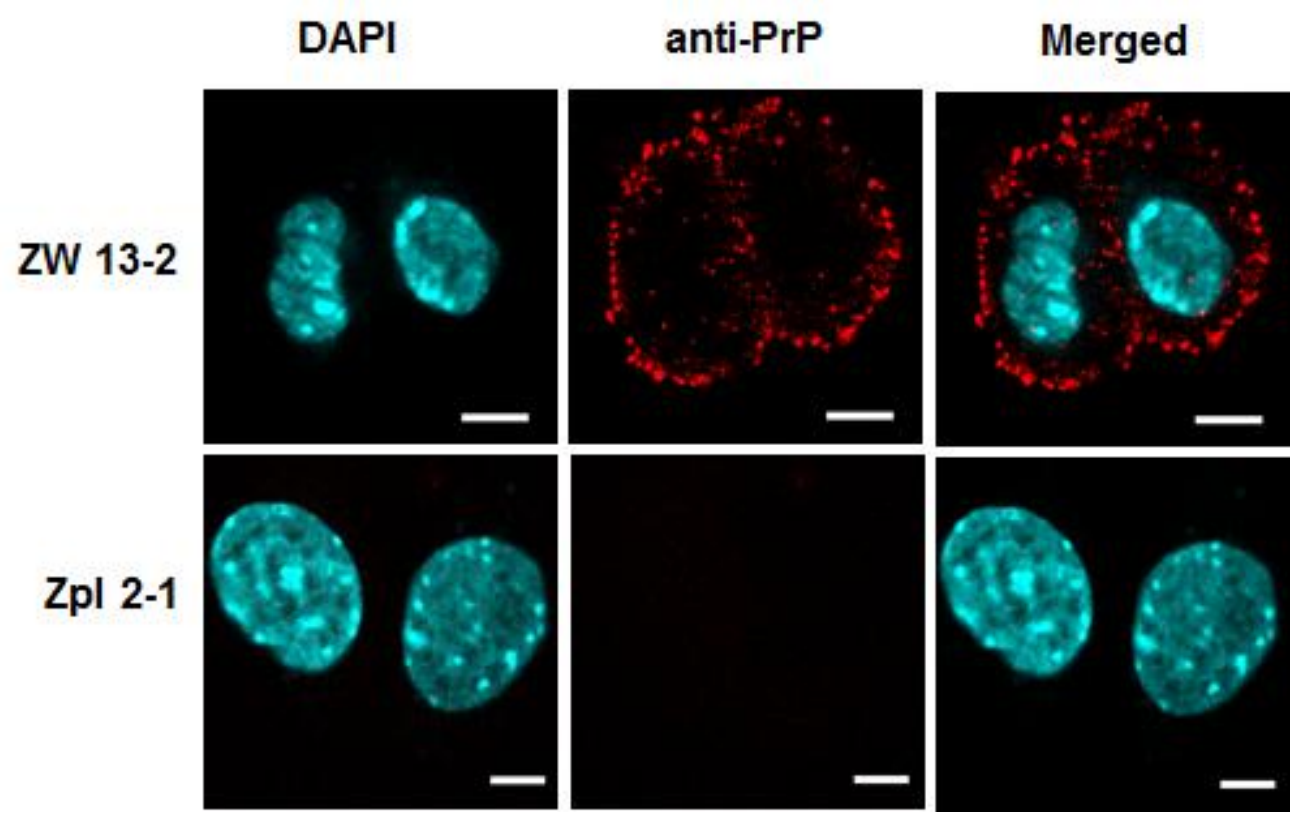

Figure 7: Immunocytochemistry verification of prion protein expression in $\mathrm{ZW} \mathrm{13-2}$ and $\mathrm{Zpl}$ 2-1 cells. PrP is immunolabeled by using the monoclonal PrP antibody SAF 32 with an Alexa 568 conjugated secondary antibody (red), nucleus is stained with DAPI (cyanine blue) and merged images are shown in the last column. Pictures were recorded by using a 60X oil immersion objective and a zooming factor of 4 . Scale bar: $5 \mu \mathrm{m}$.

To investigate the role of $\operatorname{PrP}^{\mathrm{C}}$ under transition metals-induced toxicity, we examined Zpl 2-1 and ZW 13-2 cells under $\mathrm{Cu}^{2+}, \mathrm{Zn}^{2+}, \mathrm{Mn}^{2+}$ or $\mathrm{Co}^{2+}$ treatments using a range of concentrations of each metal ion and using alamarBlue-based cell viability assay. After $24 \mathrm{~h}$ of metal treatments of the cells with various ranges of concentrations, cells proved to be 
sensitive at above $200 \mu \mathrm{M}$ to copper, manganese and cobalt and above $50 \mu \mathrm{M}$ in the case of zinc (Figure 8). Such concentration ranges of metals at which the toxicity is observable was found in other cell lines too (Choi et al., 2007; Perera and Hooper, 2001; Rachidi et al., 2009). Among the four metal ions, both cell lines were most sensitive to $\mathrm{Zn}^{2+}$ treatment showing significant differences in the number of surviving cells compared to the untreated controls even at $100 \mu \mathrm{M}$ concentrations (Figure 8B). Cells were least responsive to $\mathrm{Cu}^{2+}$ treatment, since the cell viability started to decrease significantly only at $500 \mu \mathrm{M}$ dose compared to untreated cells in case of both cell lines (Figure 8A). Nevertheless, Zpl 2-1 cells were significantly more susceptible to $\mathrm{Cu}^{2+}, \mathrm{Zn}^{2+}, \mathrm{Mn}^{2+}$ and $\mathrm{Co}^{2+}$ toxicities than $\mathrm{ZW} \mathrm{13-2} \mathrm{cells} \mathrm{at}$ all concentrations of the metal ions that fall into the toxic ranges for the cells (Figure 8).

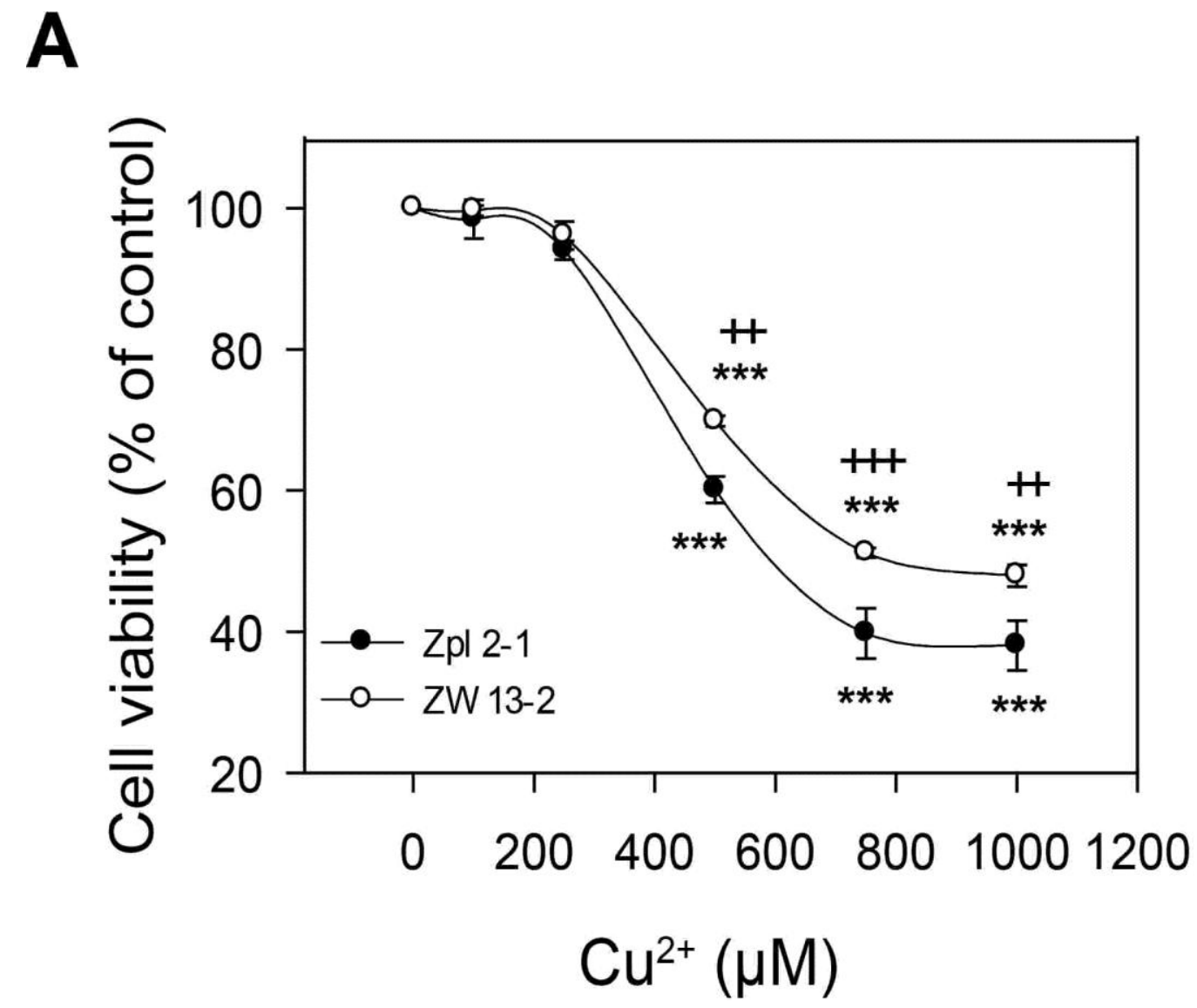


B

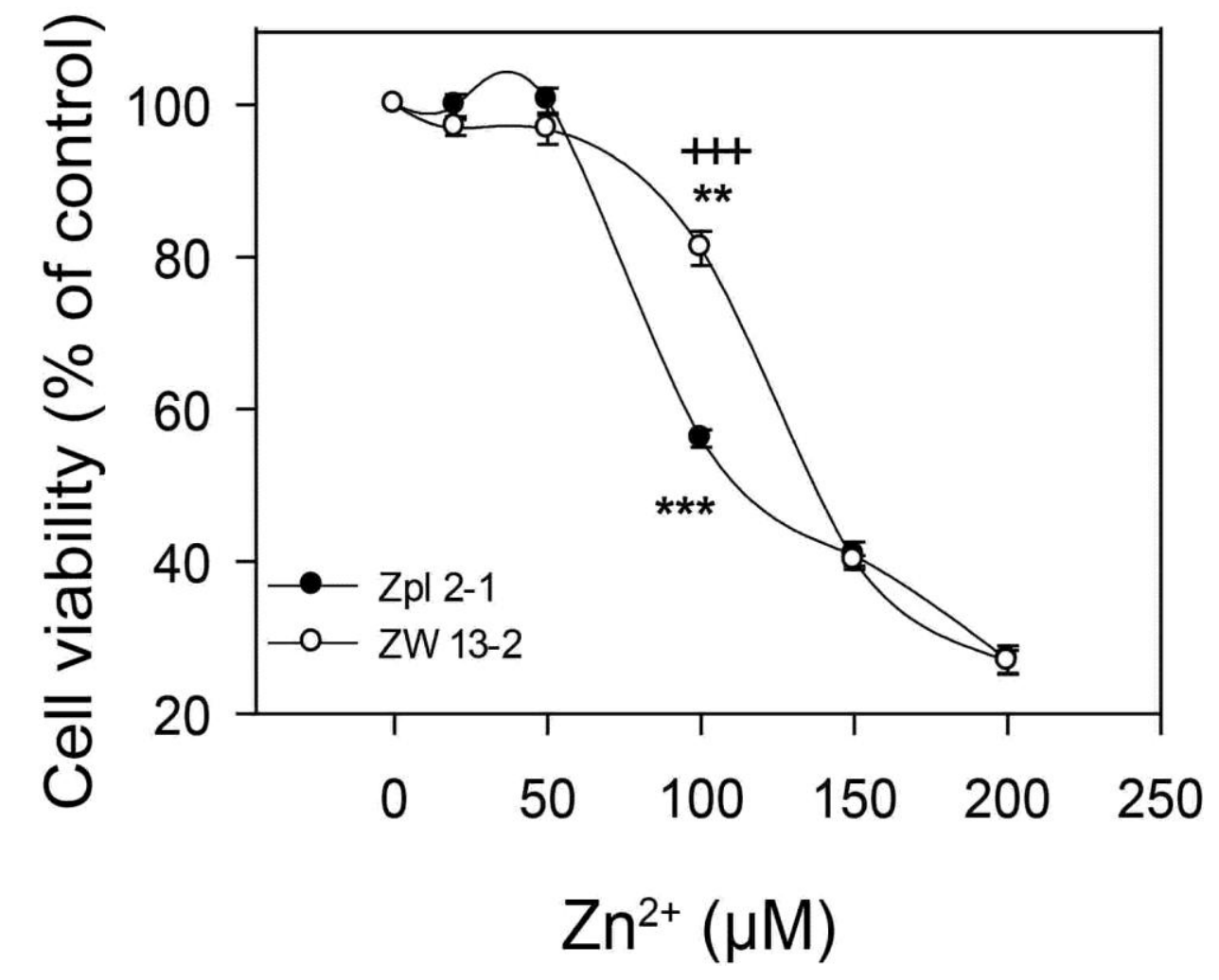

C

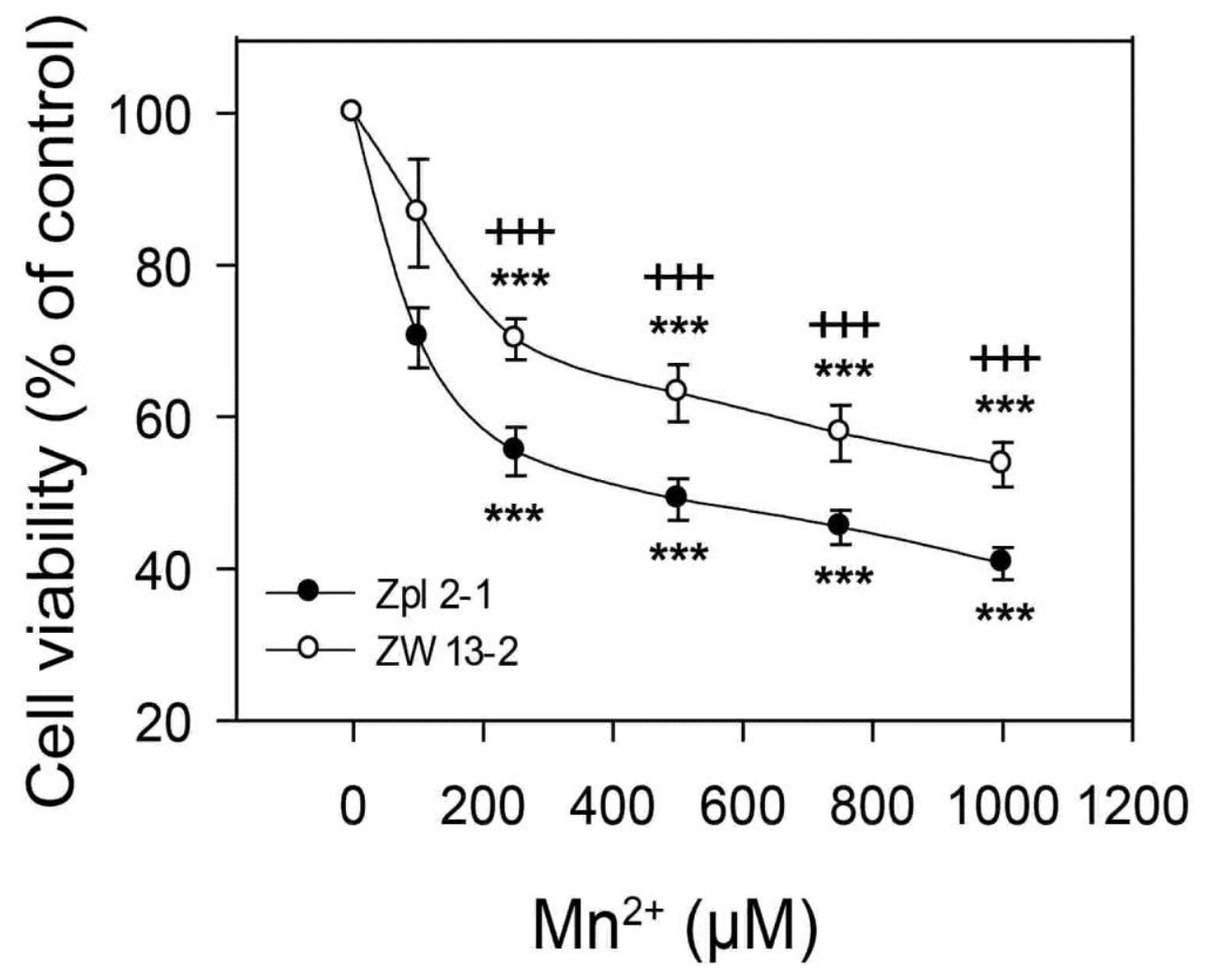




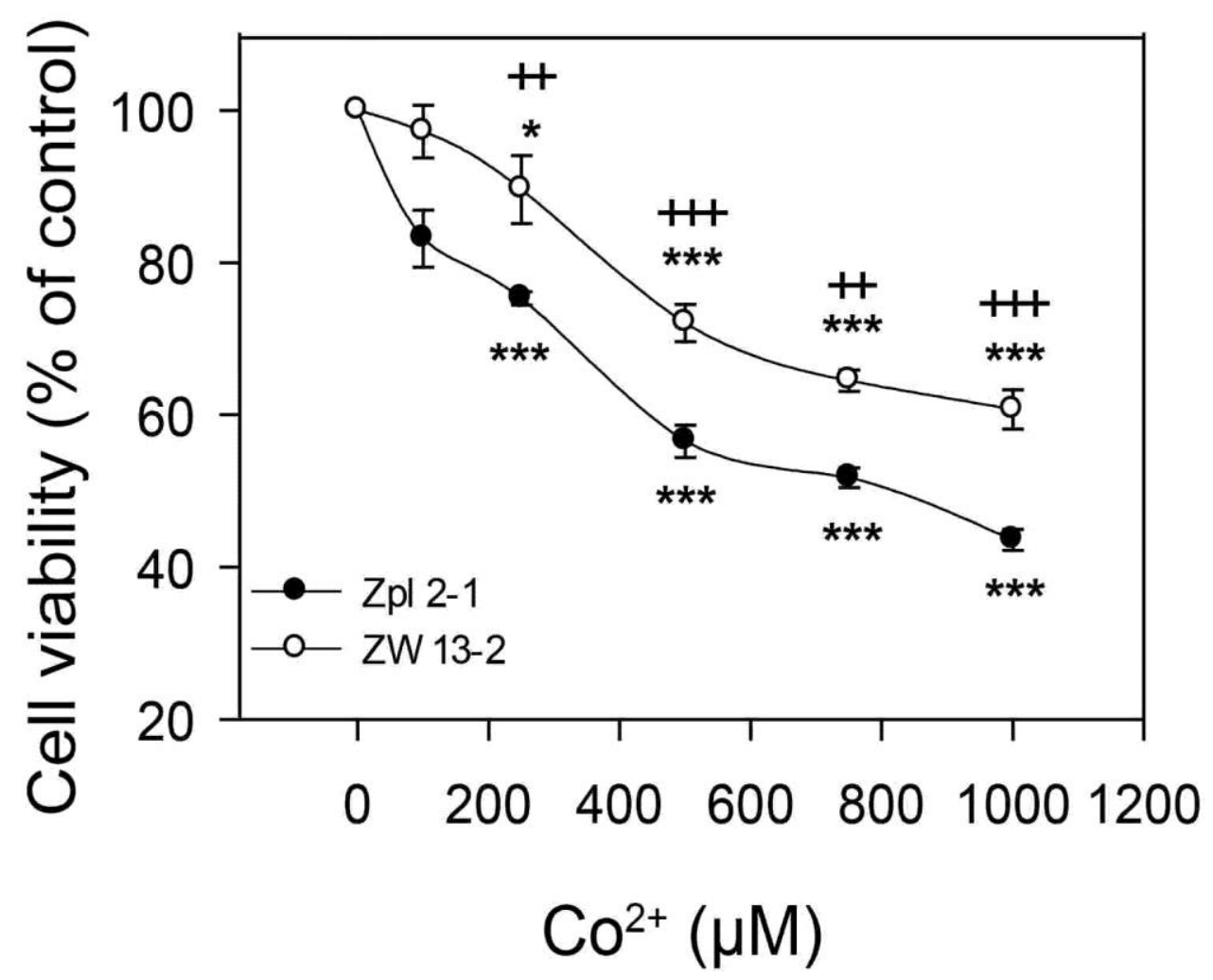

Figure 8: Sensitivity to transition metal-induced toxicity of $\mathrm{ZW} \mathrm{13-2}$ and $\mathrm{Zpl} \mathrm{2-1}$ cells. Cells were tested for survival after treatment with transition metals for $24 \mathrm{~h}$, assessing cell viability by alamarBlue assay. The cell lines ZW 13-2 (open circles) and Zpl 2-1 (black circles) were treated with increasing concentrations of either $\mathrm{Cu}^{2+}$-Gly (A) or $\mathrm{Zn}^{2+}(\mathrm{B})$, or $\mathrm{Mn}^{2+}(\mathrm{C})$ or $\mathrm{Co}^{2+}(\mathrm{D})$. Values were compared to those of the untreated controls and are presented as percentage. The data represent the means \pm standard deviation (S.D.) of minimum 3 independent experiments performed in 5 replicates. $* p<0.05$, $* * p<0.01$ and $* * * \mathrm{p}<0.001$ indicate significant differences between treated and untreated cells; ${ }^{+} \mathrm{p}<0.05,{ }^{++} \mathrm{p}<0.01$ and ${ }^{+++} \mathrm{p}<0.001$ indicate significant differences between ZW $13-2$ and $\mathrm{Zpl} 2-1$ cells

Based on the results of the cell viability analyses comparing the two cell lines, we can conclude that the ZW 13-2 cells, possessing PrP, are significantly more resistant to $\mathrm{Cu}^{2+}$, $\mathrm{Zn}^{2+}, \mathrm{Mn}^{2+}$ and $\mathrm{Co}^{2+}$ induced toxicities than $\mathrm{Zpl} 2-1$ cells.

\subsection{ZW 13-2 cells are morphologically less affected by $\mathrm{Cu}^{2+}, \mathrm{Zn}^{2+}$,}

\section{$\mathrm{Mn}^{2+}$ and $\mathrm{Co}^{2+}$ induced stresses than $\mathrm{Zpl} 2-1$ cells}


Additionally, we investigated whether ZW 13-2 and Zpl 2-1 cell lines differed in their morphological features when exposed to various concentrations of $\mathrm{Cu}^{2+}, \mathrm{Zn}^{2+}, \mathrm{Mn}^{2+}$ and $\mathrm{Co}^{2+}$ treatments using light microscopy. The observed morphological features of ZW 13-2 and $\mathrm{Zpl} 2-1$ cells exposed to $\mathrm{Cu}^{2+}, \mathrm{Zn}^{2+}, \mathrm{Mn}^{2+}$ or $\mathrm{Co}^{2+}$ revealed irregular shrinkage and cell rounding as compared with the untreated control cells. In both cell lines the number of cells attached to the surfaces of culture dishes gradually decreased with increasing concentrations of transition metals. However, there were apparently fewer attached $\mathrm{Zpl} 2-1$ cells than were ZW 13-2 cells, in a dose-dependent manner for $\mathrm{Cu}^{2+}$ (Figure 9), $\mathrm{Zn}^{2+}$ (Figure 10), $\mathrm{Mn}^{2+}$ (Figure 11) and $\mathrm{Co}^{2+}$ (Figure 12) treatments.

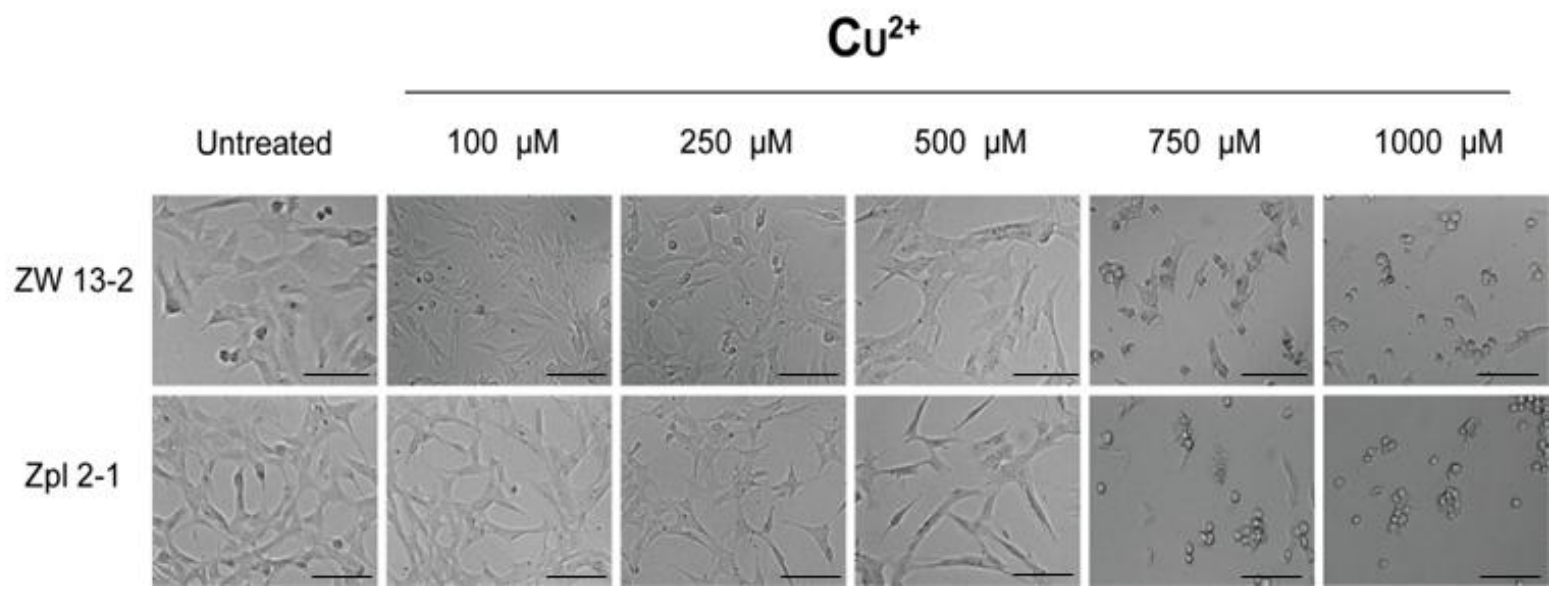

Figure 9: Morphological appearance of $\mathbf{Z W ~ 1 3 - 2 ~ a n d ~} \mathrm{Zpl} \mathrm{2-1}$ with $\mathrm{Cu}^{2+}$. ZW 13-2 and Zpl 2-1 cells, when treated with the indicated concentrations of $\mathrm{Cu}^{2+}-\mathrm{Gly}$. Transmission light microscopy images of cells recorded using a 10X objective. Scale bar: $100 \mu \mathrm{m}$.

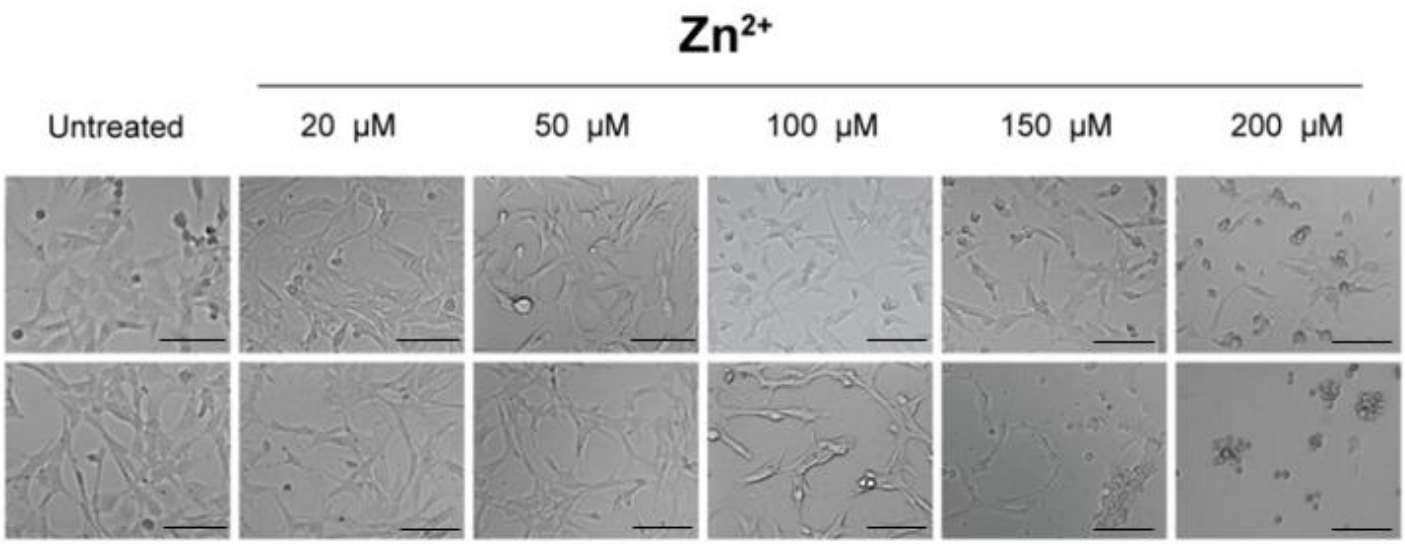


Figure 10: Morphological appearance of $\mathbf{Z W ~ 1 3 - 2}$ and $\mathbf{Z p l ~ 2 - 1}$ with $\mathbf{Z n}^{2+}$. ZW 13-2 and $\mathrm{Zpl} 2$-1cells treated with the indicated concentrations of $\mathrm{Zn}^{2+}$. Transmission light microscopy images of cells, acquired using a 10X objective. Scale bar: $100 \mu \mathrm{m}$.

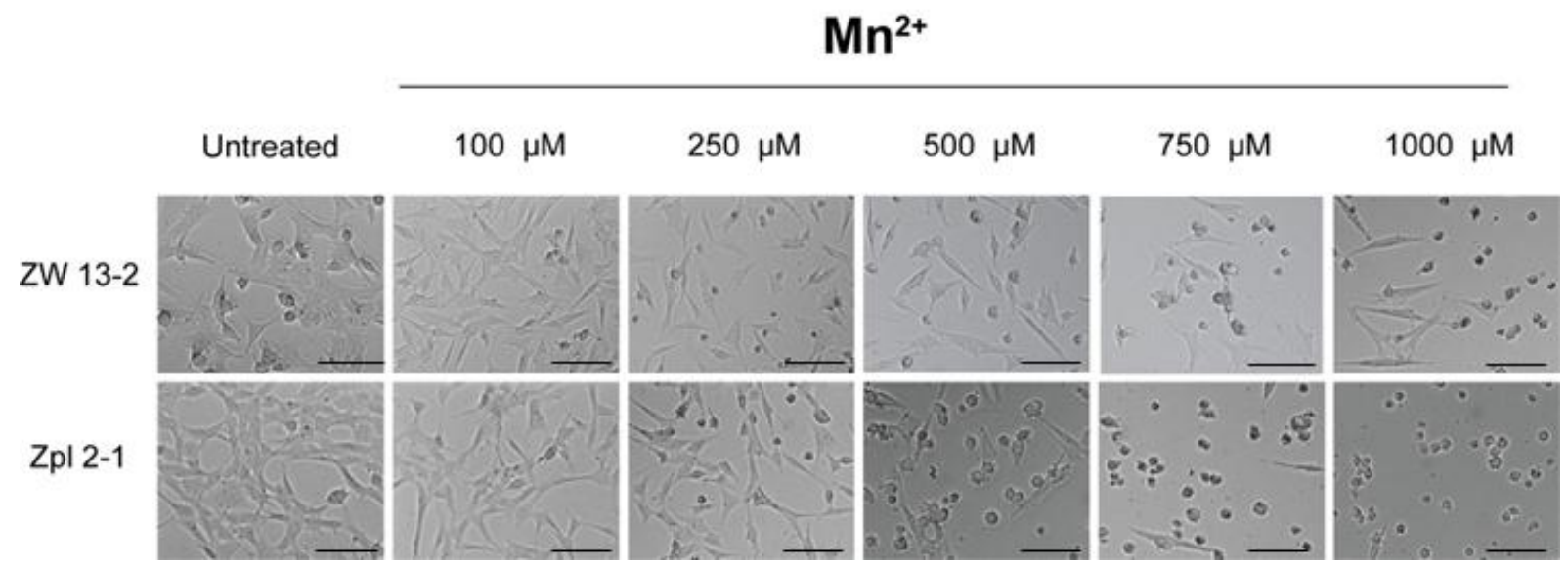

Figure 11: Morphological appearance of ZW 13-2 and Zpl 2-1 with $\mathbf{M n}^{2+}$. ZW 13-2 and $\mathrm{Zpl} 2$ 2-1cells treated with the indicated concentrations of $\mathrm{Mn}^{2+}$. Transmission light microscopy images of cells acquired using a 10X objective. Scale bar: $100 \mu \mathrm{m}$.

1

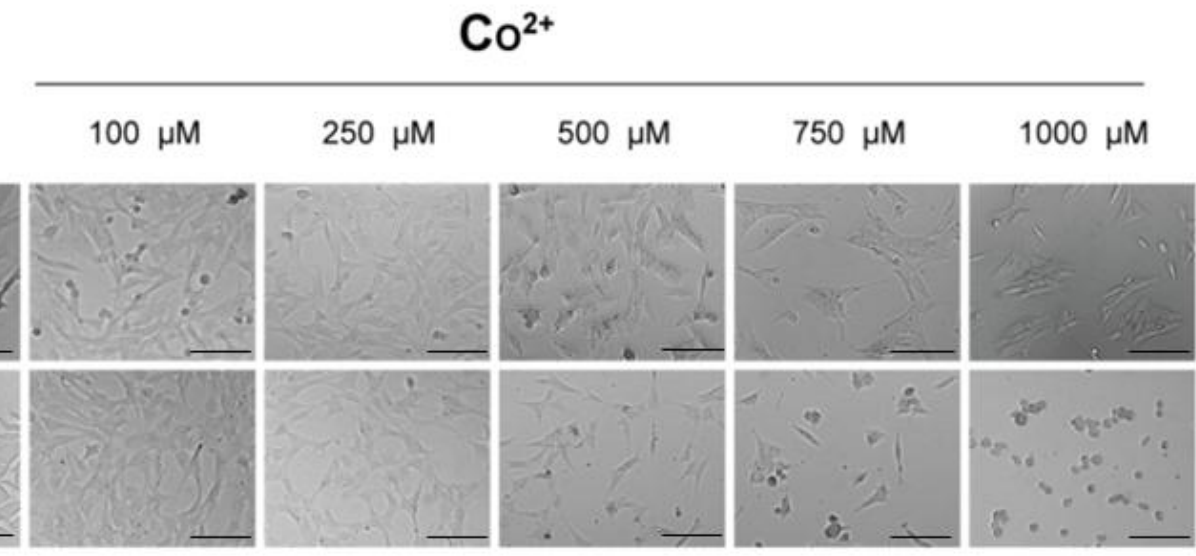

Figure 12: Morphological appearance of ZW 13-2 and Zpl 2-1 with $\mathrm{Co}^{2+}$. ZW 13-2 and $\mathrm{Zpl} \mathrm{2-1} \mathrm{(A)} \mathrm{and} \mathrm{of} \mathrm{Zpl} \mathrm{2-1-vector} \mathrm{and} \mathrm{Zpl} \mathrm{2-1-PrP} \mathrm{(B)} \mathrm{cells} \mathrm{treated} \mathrm{with} \mathrm{the} \mathrm{indicated}$ concentrations of $\mathrm{Co}^{2+}$. Transmission light microscopy images of cells recorded using a $10 \mathrm{X}$ objective. Scale bar: $100 \mu \mathrm{m}$.

These findings clearly demonstrate that PrP-expressing ZW 13-2 control cells are morphologically less affected by the $\mathrm{Cu}^{2+}, \mathrm{Zn}^{2+}, \mathrm{Mn}^{2+}$ and $\mathrm{Co}^{2+}$ induced stresses than Zürich I Zpl 2-1 neuronal cells, the latter proving to be morphologically more susceptible to the same treatments. 
In conclusion, based on cell viability analyses and morphological appearance, PrP expressing wild type $\mathrm{ZW} 13-2$ cells were significantly more resistant to $\mathrm{Cu}^{2+}, \mathrm{Zn}^{2+}, \mathrm{Mn}^{2+}$ and $\mathrm{Co}^{2+}$ induced toxicities than PrP-ablated $\mathrm{Zpl} 2-1$ cells, which is consistent with the contention that $\mathrm{PrP}^{\mathrm{C}}$ may play a protective role against $\mathrm{Cu}^{2+}, \mathrm{Zn}^{2+}, \mathrm{Mn}^{2+}$ and $\mathrm{Co}^{2+}$ cytotoxicity..

\subsection{Generation of stable prion protein expressing $\operatorname{Prnp}^{-/-}$(Zpl 2-1)}

\section{neuronal cell lines}

To confirm whether the prion itself is solely responsible for the protective effect against transition metals induced toxicity found in the case of ZW 13-2 and Zpl 2-1 cells, we used the $\operatorname{Prnp}^{-/-}(\mathrm{Zpl} 2-1)$ knock out cell line and re-introduce the Prnp gene into the cells, by stably transfecting it with a DNA construct encoding mouse PrP using the Sleeping Beauty (SB) transposase system. The SB transposase system mediated gene integration had been extensively studied and it is nowadays widely used to generate stable integrations of genes (Grabundzija et al., 2010; Kolacsek et al., 2014). It induces stable integration and reliable long-term expression of the gene of interest and its efficiency is higher than that of the random integration by up to two orders of magnitude. The vector used in this study is designed so that it also contains an EGFP expression cassette to facilitate the selection of the cells with integrated transgenes. The coupled integration of the two expression cassettes (PrP and EGFP) between the transposon arms has been demonstrated, and it made feasible the selection of the successful transformants by FACS. Thus, instead of cloning the stably transfected cells, a cell population could be produced with various random sites of transgene integration, averaging out the potential positional effects of individual integrations on the outcome of the experiments. An only-EGFP-expressing vector was also used for the purpose 
to generate control cells (Zpl 2-1-vector) along with the Zpl 2-1-PrP cells, in order to be able to rule out later the possibility of other factors than $\operatorname{PrP}^{\mathrm{C}}$ expression alone, to play role in the restoration of protection against metals induced toxicity in Zpl 2-1 cells.

By using Western blot and immunocytochemical analyses, we tested the expression of $\operatorname{PrP}^{\mathrm{C}}$ in established Zpl 2-1-PrP and Zpl 2-1-vector cell lines. Total cell lysates of Zpl 2-1vector and Zpl 2-1-PrP hippocampal neuronal cells were collected and were either left untreated or were treated by PNGase F before immunoblotting with monoclonal PrP antibody SAF 32 (Figure 13).

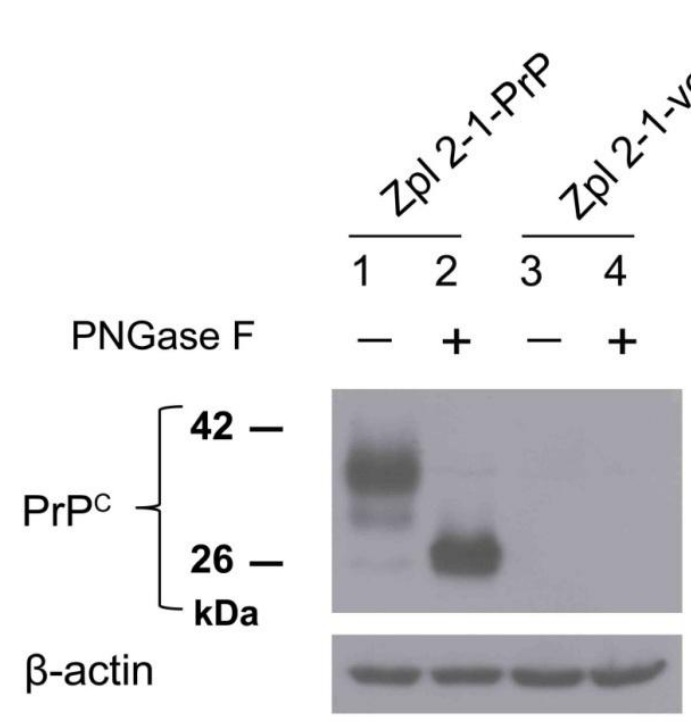

Figure 13: Western blotting performed to verify expression levels of $\operatorname{Pr} P$ in the generated stable $\mathrm{Zpl}$ 2-1-vector and $\mathrm{Zpl}$ 2-1-PrP cell lines. Total cell lysates of stably expressing cells made from Prnp-/- hippocampal neuronal cell line of Zürich I mice (Zpl 21) transfected with either the empty vector (Zpl 2-1-vector) or with mouse PrP gene (Zpl 2-1PrP). Cell lysates were incubated in the absence (lane 1 and lane 3) or presence of PNGase F (lane 2 and lane 4). Western blot analysis was carried out with monoclonal PrP antibody SAF 32. $\beta$-actin was used to confirm equal loading of proteins.

Zpl 2-1-PrP cells exhibit a well-detectable level of $\operatorname{PrP}^{\mathrm{C}}$ expression. The detected bands were properly N-glycosylated as judged by the bands in the PNGase treated and untreated samples (lanes 1 and 2, Figure 13) whereas, The Zpl 2-1-vector cells, where there is no expected expression of prion, showed no detectable bands for PrP (lane 3 and 4, Figure 13). In addition, 
prion expression and localization were confirmed by immunocytochemical analysis of the fixed cells (Figure 14). Cell imaging was performed similarly as in the case of ZW 13-2 and Zpl 2-1 cells (Fig. 7) according to the method I had optimized in Molnar et al. (Molnár et al., 2013). The bright red immunofluorescence-staining pattern in the Zpl 2-1-PrP cells revealed that the prion protein was distributed on the surface of the cells, whereas no immunoreactivity was detected in the Zpl 2-1-vector cells.

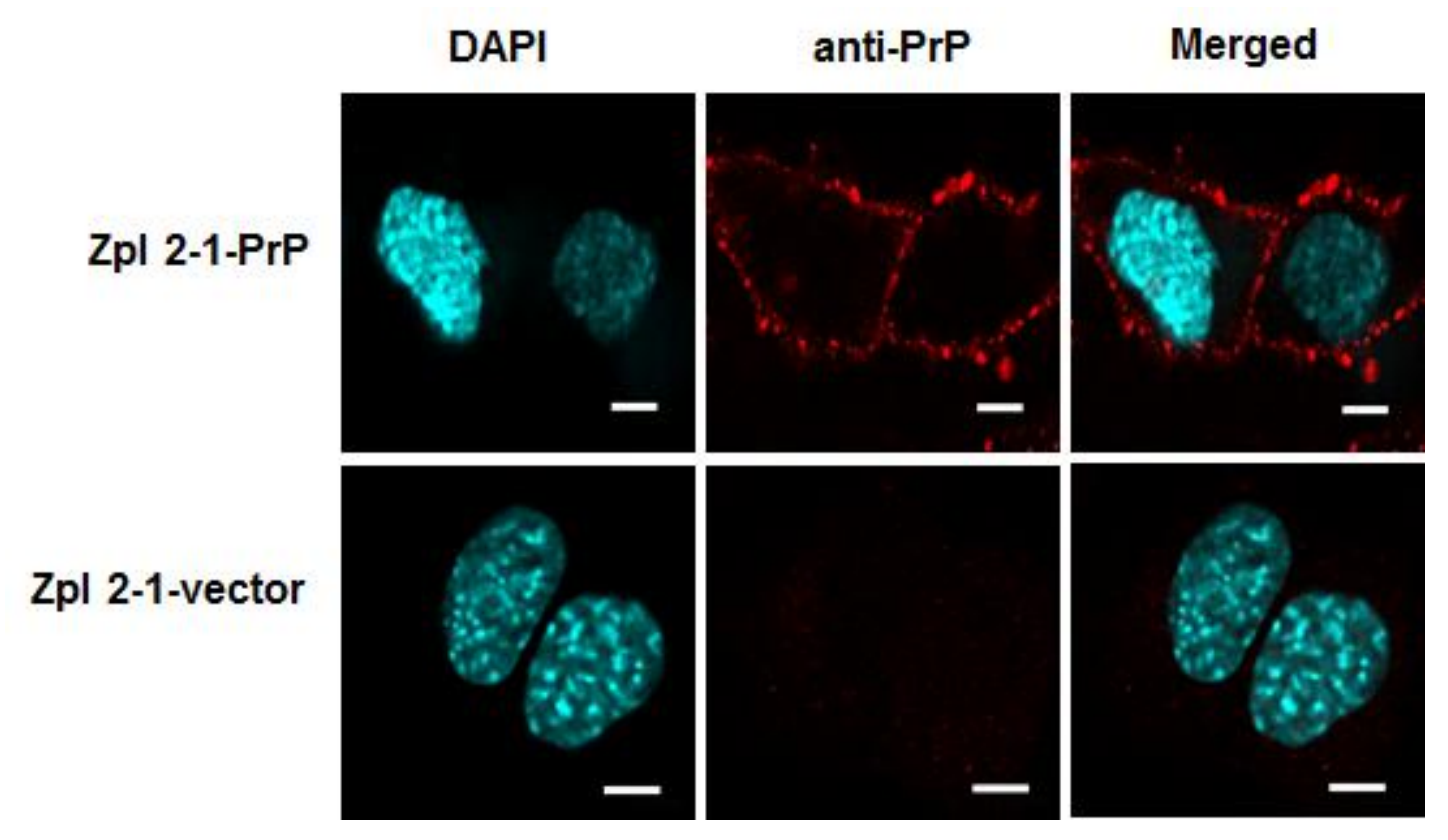

Figure 14: Immunocytochemistry performed to verify prion protein expression in Zpl 21- PrP and Zpl 2-1-vector cells. PrP is immunolabeled by the monoclonal PrP antibody SAF 32 and an Alexa 568 conjugated secondary antibody (red), nucleus is stained with DAPI (cyanine blue) and merged image is shown in the last column. Pictures were recorded using a $60 \mathrm{X}$ oil immersion objective and a zooming factor of 4 . Scale bar: $5 \mu \mathrm{m}$.

Microscopic pictures have also been taken at lower magnification in order to visualize the percentage of PrP expressing cells in the population. The number of transformant cells was estimated based on the microscopy pictures using the counts of DAPI stained cells as the total cells and the Alexa568 positive cells as counts of the transformant cells. We found that $90(+/-1.7) \%$ of the $\mathrm{Zpl} 2-1-\mathrm{PrP}$ cells express $\mathrm{PrP}$ on the surface, whereas, we found no positively stained cells of the vector-expressing cells (Figure 15). 


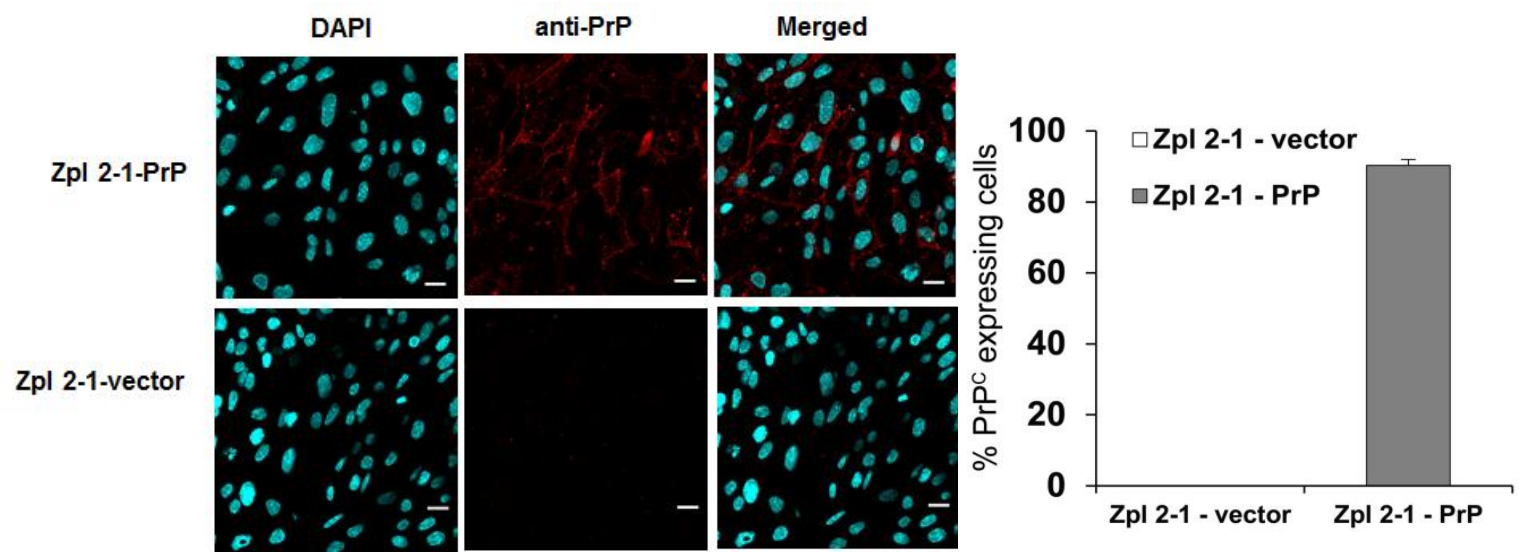

Figure 15: The percentage of $\operatorname{PrP}$ expressing cells in $\mathrm{Zpl}$ 2-1- $\mathrm{PrP}$ and $\mathrm{Zpl}$ 2-1-vector cells. (Pictures were recorded using a 60X oil immersion objective and a zooming factor of 1 . Scale bar: $20 \mu \mathrm{m}$.

The expression levels of $\mathrm{PrP}^{\mathrm{C}}$ in $\mathrm{Zpl}$ 2-1-PrP cells were also compared to the expression levels present in the wild type ZW 13-2 cells by using western blot analysis (Figure 16).

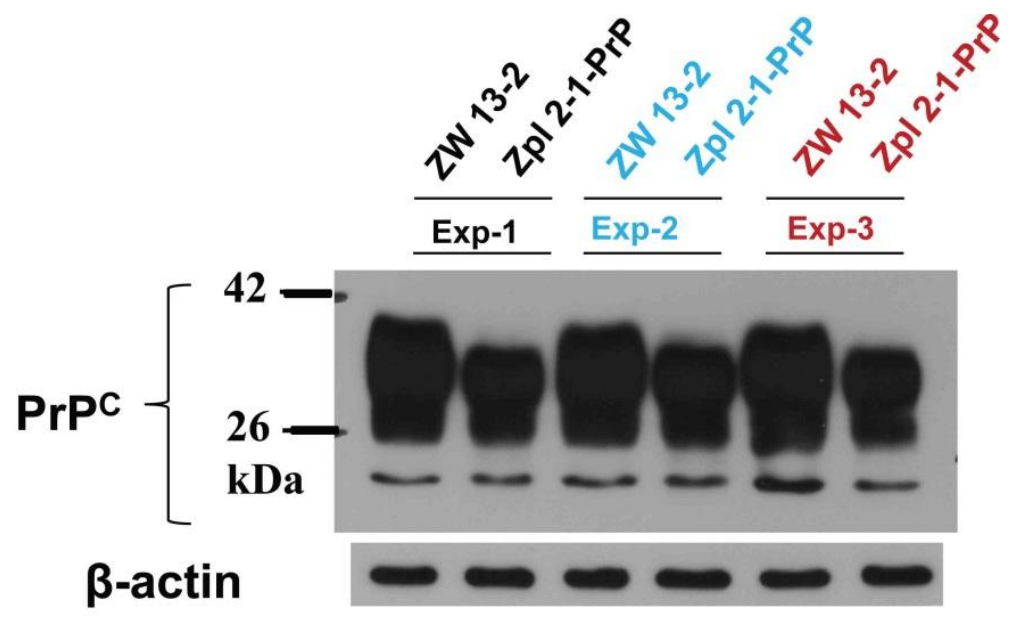

Figure 16: The expression of $\operatorname{PrP}$ in $\mathrm{ZW} \mathrm{13-2}$ and $\mathrm{Zpl}$ 2-1-PrP stable cell. Western blot analysis with the monoclonal PrP antibody SAF 32 in cell lysates from ZW 13-2 and Zpl 2-1 transfected with mouse $\operatorname{PrP}$ gene $(\mathrm{Zpl} 2-1-\mathrm{PrP})$ cell lines. $\beta$-actin was used to confirm equal loading of proteins. 
Figure 16 shows three independent samplings (Exp-1,2,3) of the two cells where the total cell lysates collected at the three occasions were blotted at the same time to look for PrP. By using densitometry analysis, the bands corresponding to the prion protein were normalized with the bands corresponding to the $\beta$-actin used as loading control on Fig 16, and the PrP leves were quantified (Figure 17).

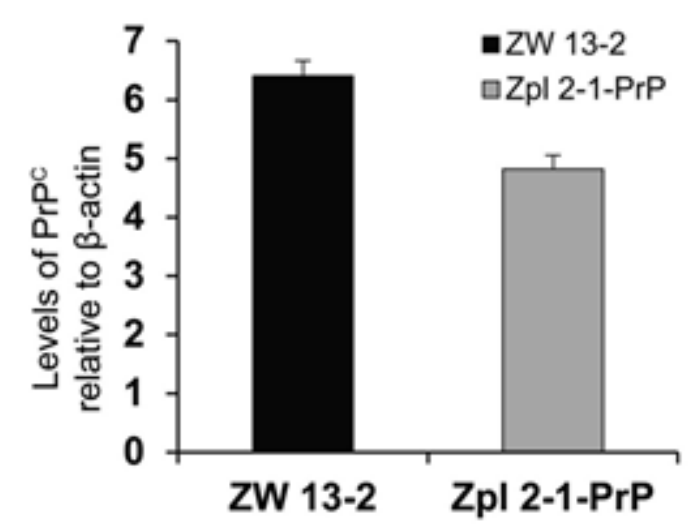

Figure 17: Relative expressions of PrP from ZW 13-2 and Zpl 2-1-PrP cell lines. The expression of $\operatorname{PrP}^{\mathrm{C}}$ is quantified using densitometry analysis, the bars represent the average value obtained from three independent western blots and the error bars represent the standard deviations.

As can be seen on Figure 17 the prion protein expression levels were comparable in Zpl 2-1-PrP and ZW 13-2 cells.

We can conclude that the generated stable Zpl 2-1-PrP transgenic cell line possesses comparable levels of PrP expression to the wild type ZW 13-2 cell line, and that the expressed PrP has similar localization and glycosylation to the PrP in the wild type cell, making the generated Zpl 2-1-PrP cell line suitable for a comparative study on the prion protein.

\subsection{Zpl 2-1-PrP cells are not significantly more resistant to $\mathrm{Cu}^{2+}$,}




\section{$\mathrm{Zn}^{2+}, \mathrm{Mn}^{2+}$ and $\mathrm{Co}^{2+}$ induced toxicities than its control $\mathrm{Zpl}$ 2-1- vector cells}

To verify whether the presence of cellular prion protein was the only accountable factor for the difference found in the susceptibilities of PrP-expressing ZW 13-2 cells and $\operatorname{Prnp}^{-/} \mathrm{Zpl} 2-1$ cells against metal toxicity (Chapter 4.1 and 4.2), we treated Zpl 2-1-PrP and Zpl 2-1-vector cells characterized above (Figure 13-17) with the same metals $\mathrm{Cu}^{2+}, \mathrm{Zn}^{2+}$, $\mathrm{Mn}^{2+}$ and $\mathrm{Co}^{2+}$ at the same concentrations as on Figure 8 and assessed their survival using alamarBlue-based assay (Figure 18A, B, C and D). 
A

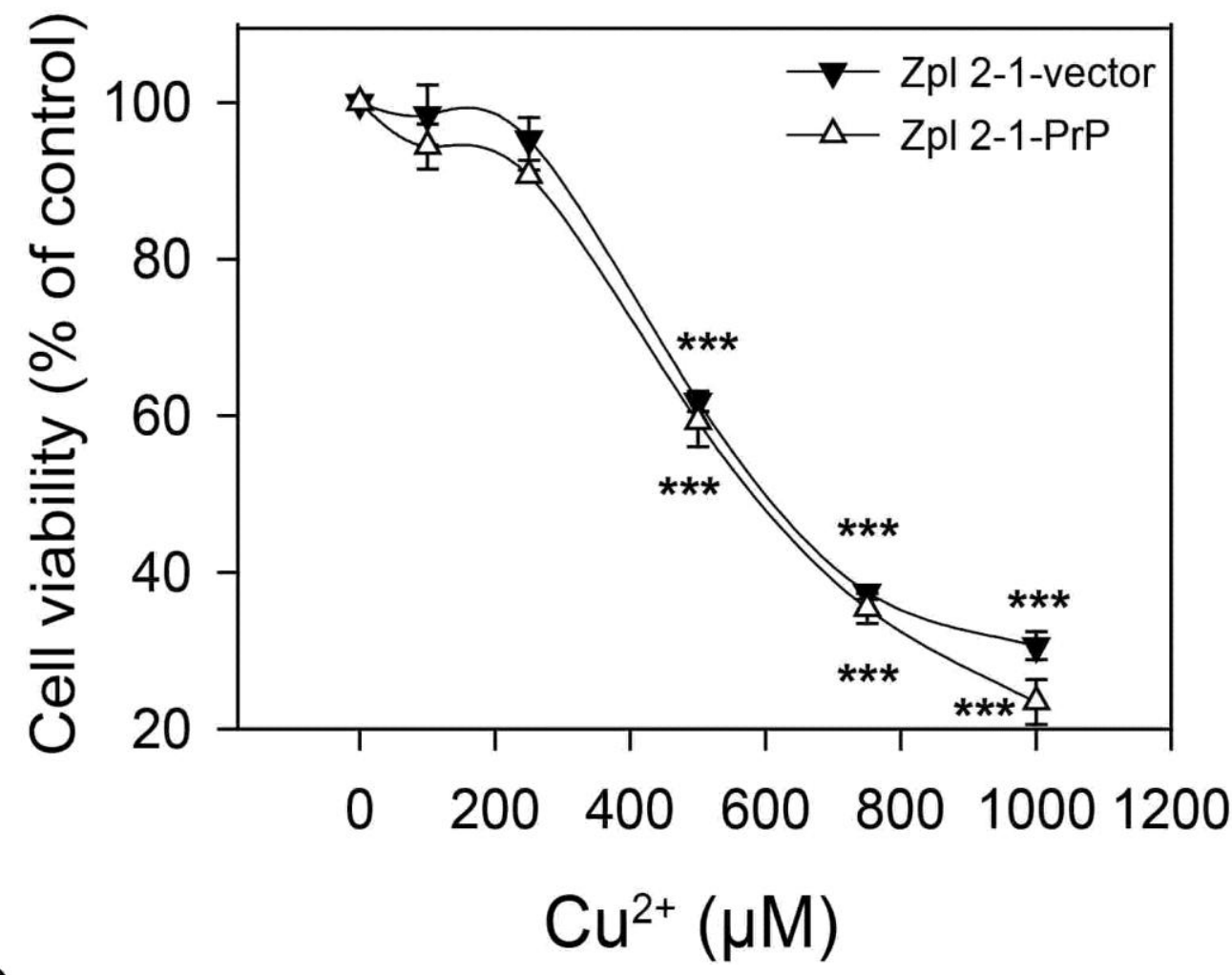

B

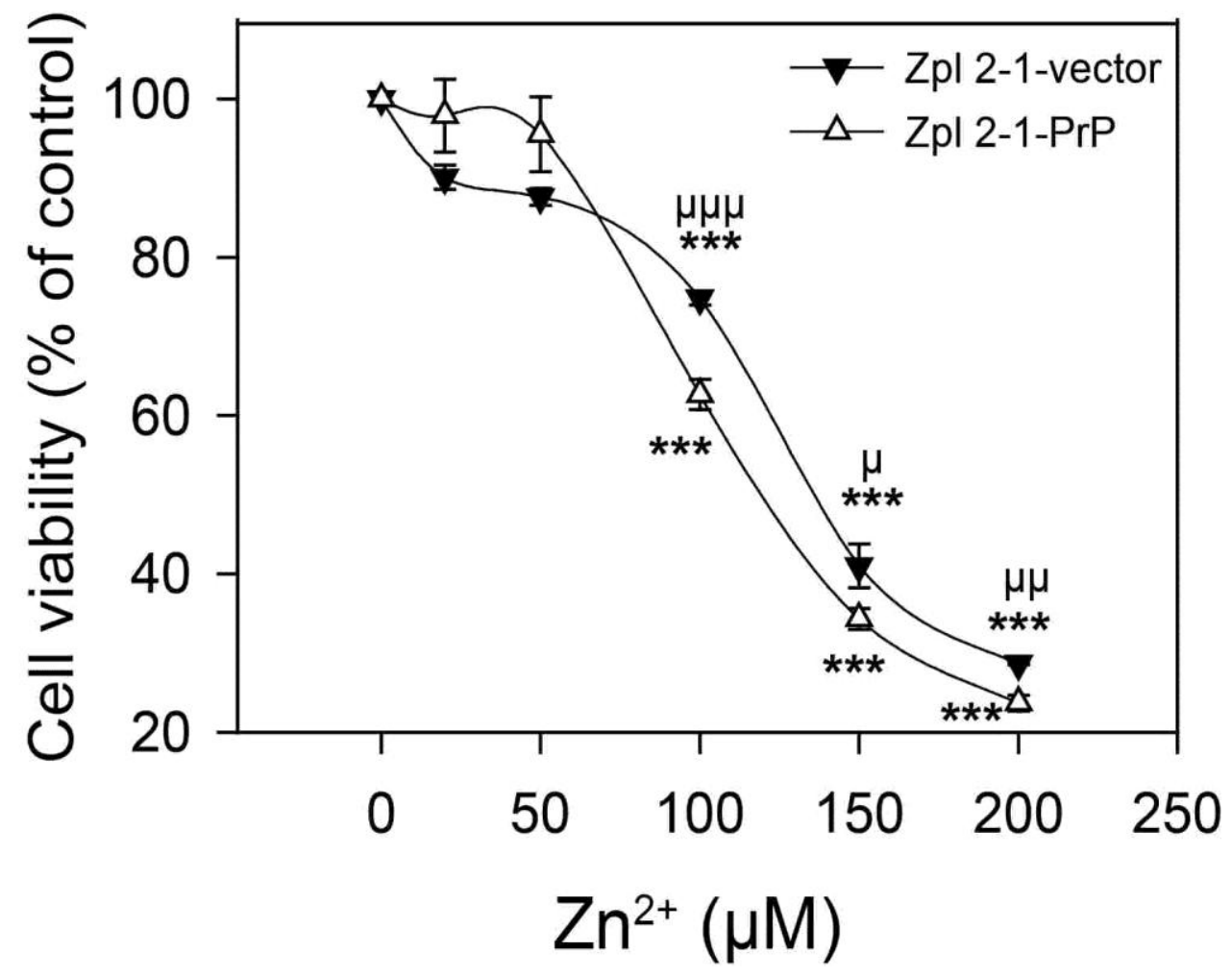


C

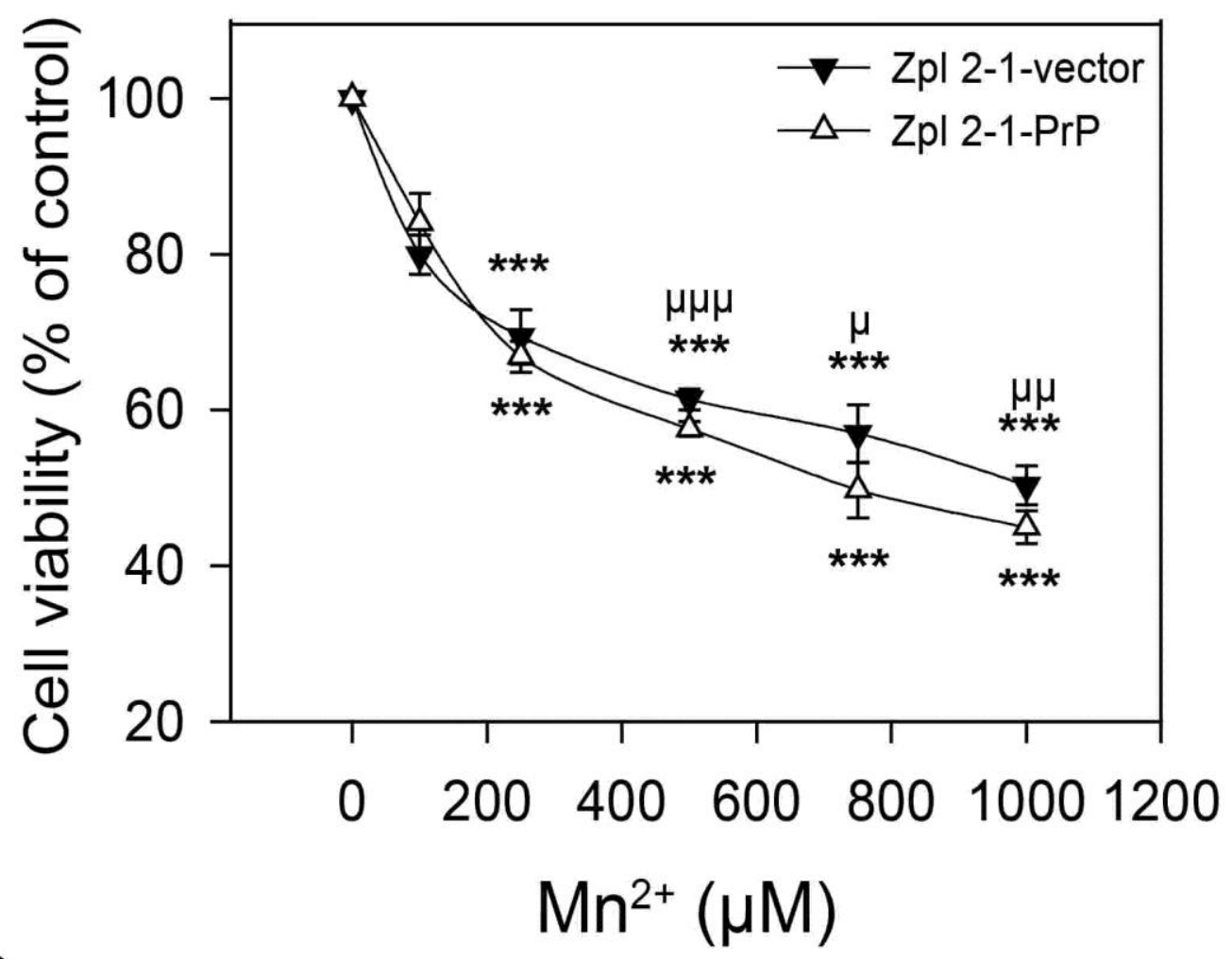

D

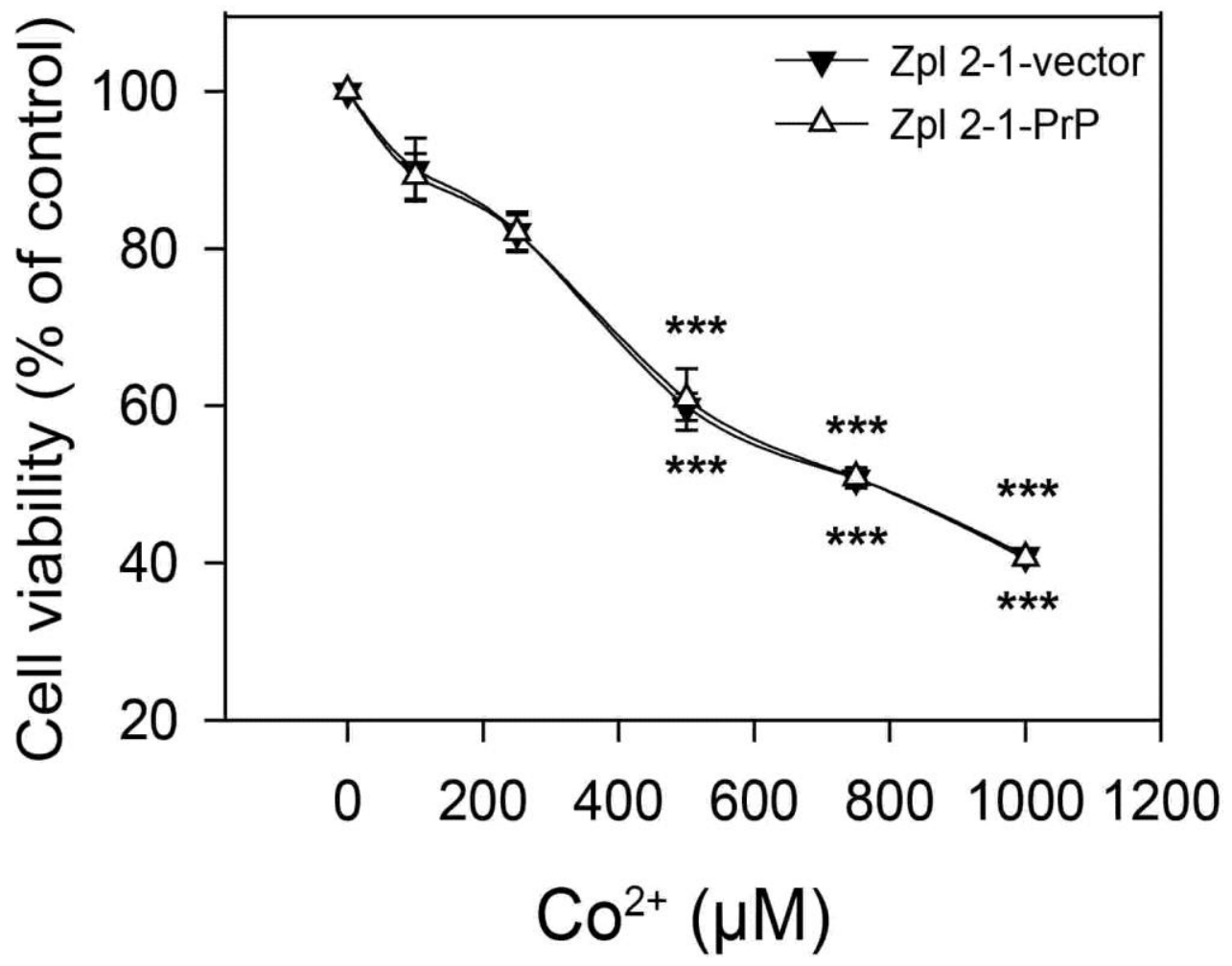

Figure 18: The effect of the presence of $\operatorname{PrP}^{\mathrm{C}}$ on the susceptibility of cells to transition metal-induced toxicity. Cells were tested for survival after treatment with transition metals 
for $24 \mathrm{~h}$ and cell viability was determined using alamarBlue assay. Values are compared to those of the untreated controls and are expressed as percentage. The cells Zpl 2-1-PrP (open triangles) and $\mathrm{Zpl} \mathrm{2-1-vector} \mathrm{(black} \mathrm{triangles)} \mathrm{are} \mathrm{compared} \mathrm{(panels} \mathrm{A} \mathrm{through} \mathrm{D}$ ) during treatments with increasing concentrations of metals, as follows: $\mathrm{Cu}^{2+}-\mathrm{Gly}(\mathrm{A})$, of $\mathrm{Zn}^{2+}(\mathrm{B})$, $\mathrm{Mn}^{2+}(\mathrm{C})$ and $\mathrm{Co}^{2+}(\mathrm{D})$. The data are presented as means \pm standard deviation (S.D.) of minimum 3 independent experiments performed in 5 replicates. $* p<0.05, * * p<0.01$ and $* * * p<0.001$ indicate significant differences between treated and untreated cells on panels $\mathrm{A}$ through $\mathrm{D} ;{ }^{\mu} \mathrm{p}<0.05,{ }^{\mu \mu} \mathrm{p}<0.01$ and ${ }^{\mu \mu \mu} \mathrm{p}<0.001$ indicate significant differences between treated Zpl 2-1-PrP cells and treated Zpl 2-1-vector cells.

Treatment with these metals significantly decreased cell viability in both Zpl 2-1-PrP and Zpl 2-1-vector cells compared to the untreated controls at the same metal ion concentrations. The concentration range where the cells proved to be sensitive to metal ion after a $24 \mathrm{~h}$ treatment was above $200 \mu \mathrm{M}$ for $\mathrm{Cu}^{2+}, \mathrm{Mn}^{2+}$ and $\mathrm{Co}^{2+}$ (Figure 18A, C and D) and above $50 \mu \mathrm{M}$ in the case of $\mathrm{Zn}^{2+}$ (Figure 18B). Among the four metal ions, cells showed to be the most sensitive to $\mathrm{Zn}^{2+}$ treatment, during which cell viability started to decrease significantly at as little as $100 \mu \mathrm{M}$ concentration compared to untreated cells in case of both cell lines (Figure 18B). $\operatorname{PrP}$ expressing $\mathrm{Zpl} 2-1-\mathrm{PrP}$ cells showed to be significantly more sensitive to $\mathrm{Zn}^{2+}$ and $\mathrm{Mn}^{2+}$ induced toxicities than its control $\mathrm{Zpl} 2$-1-vector cells but not in case of $\mathrm{Cu}^{2+}$ and $\mathrm{Co}^{2+}$ treatments.

These results show that the PrP expressing Zpl 2-1-PrP cells are not significantly more resistant to $\mathrm{Cu}^{2+}, \mathrm{Zn}^{2+}, \mathrm{Mn}^{2+}$ and $\mathrm{Co}^{2+}$ induced toxicities than its control $\mathrm{Zpl} 2$-1-vector cells, even though the $\operatorname{PrP}$ expression in $\mathrm{Zpl} 2-1-\mathrm{PrP}$ cell line is present (and at a level comparable to that in the $\mathrm{ZW}$ cells), whereas in the $\mathrm{Zpl} 2$-1-vector cell line it is not.

After this puzzling finding we wanted to see how the viability levels of these two lines compare to the original Zpl 2-1 and wild type ZW 13-2 cells. The comparisons are presented on Figure 19. 
A

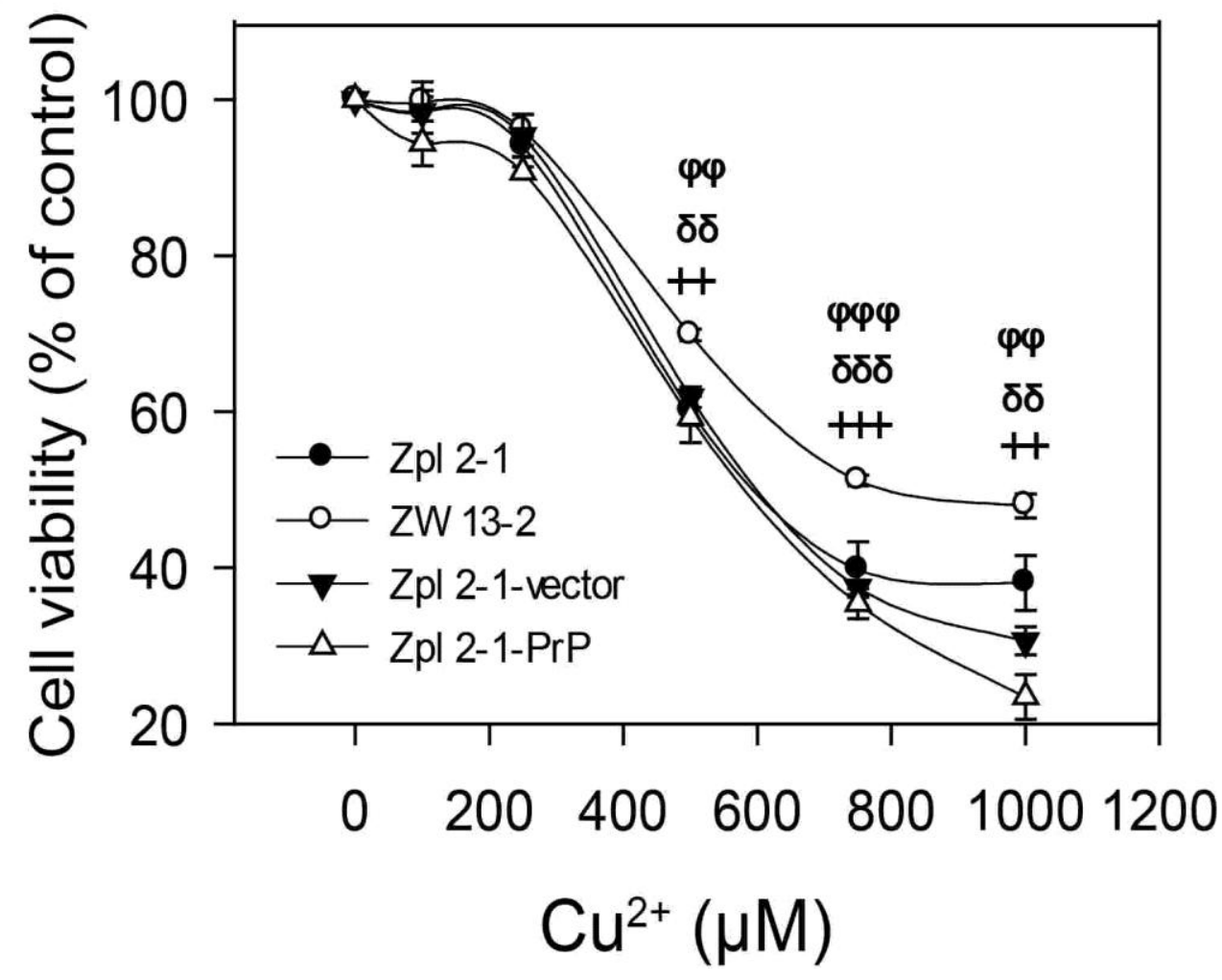

B

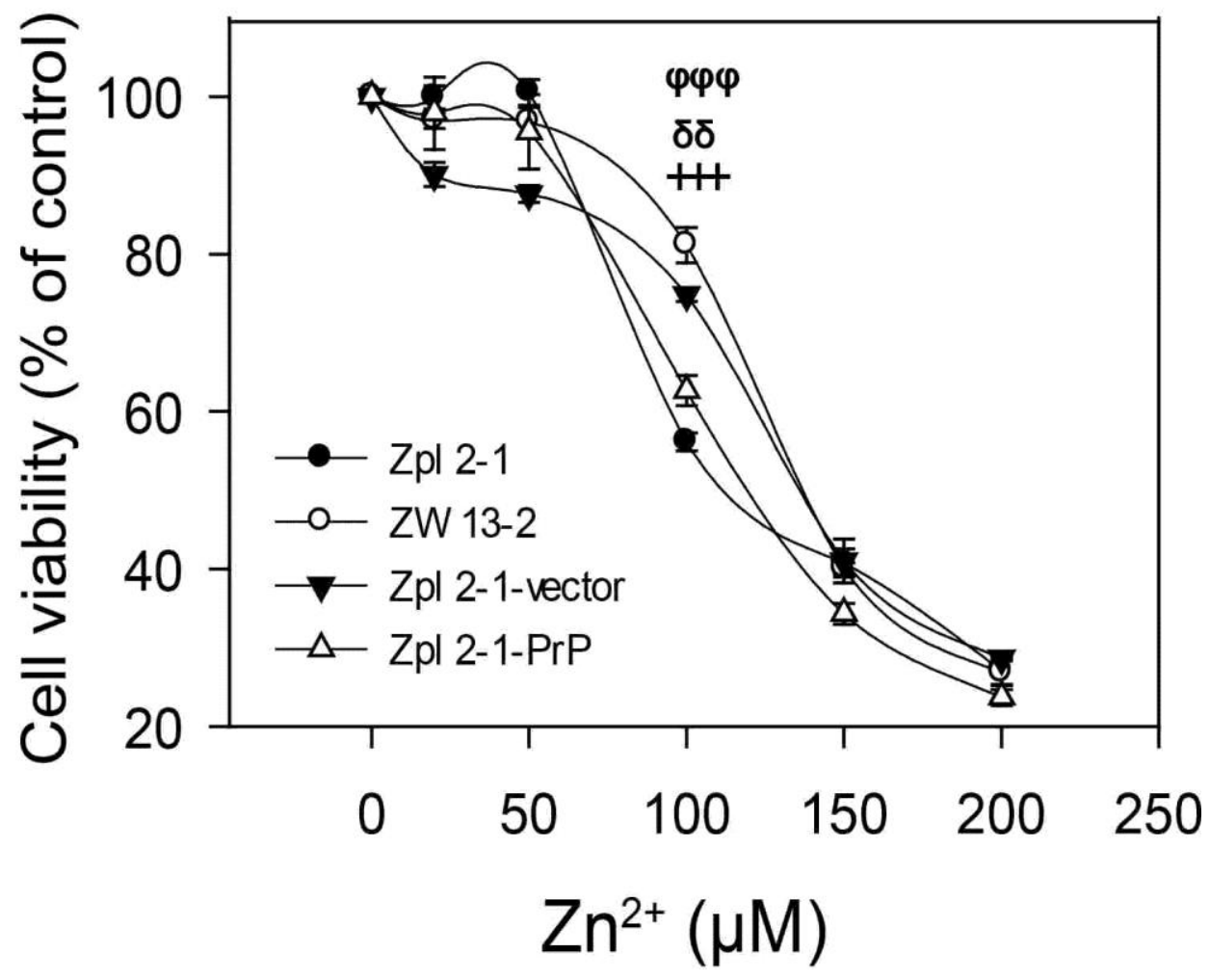


C

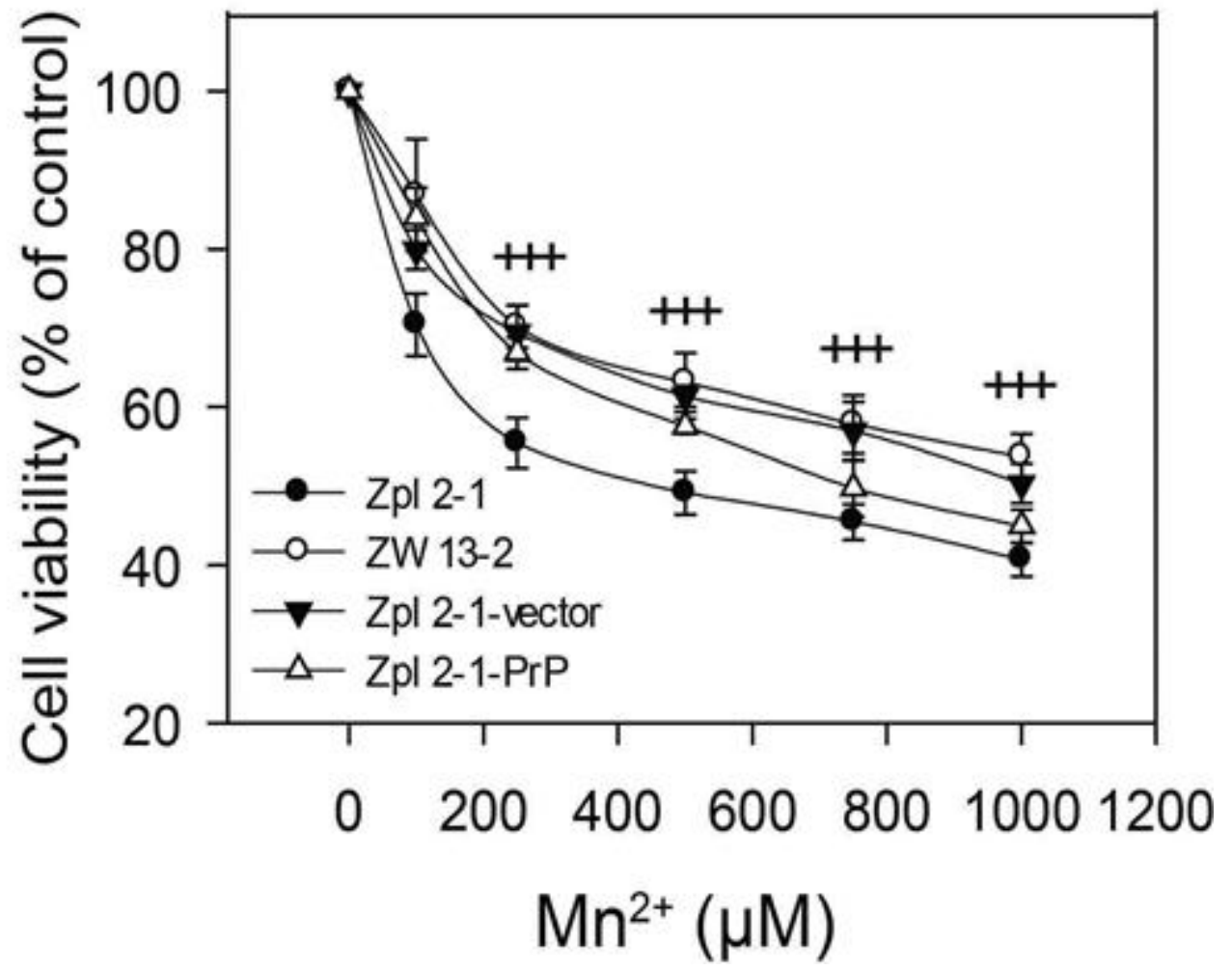

D

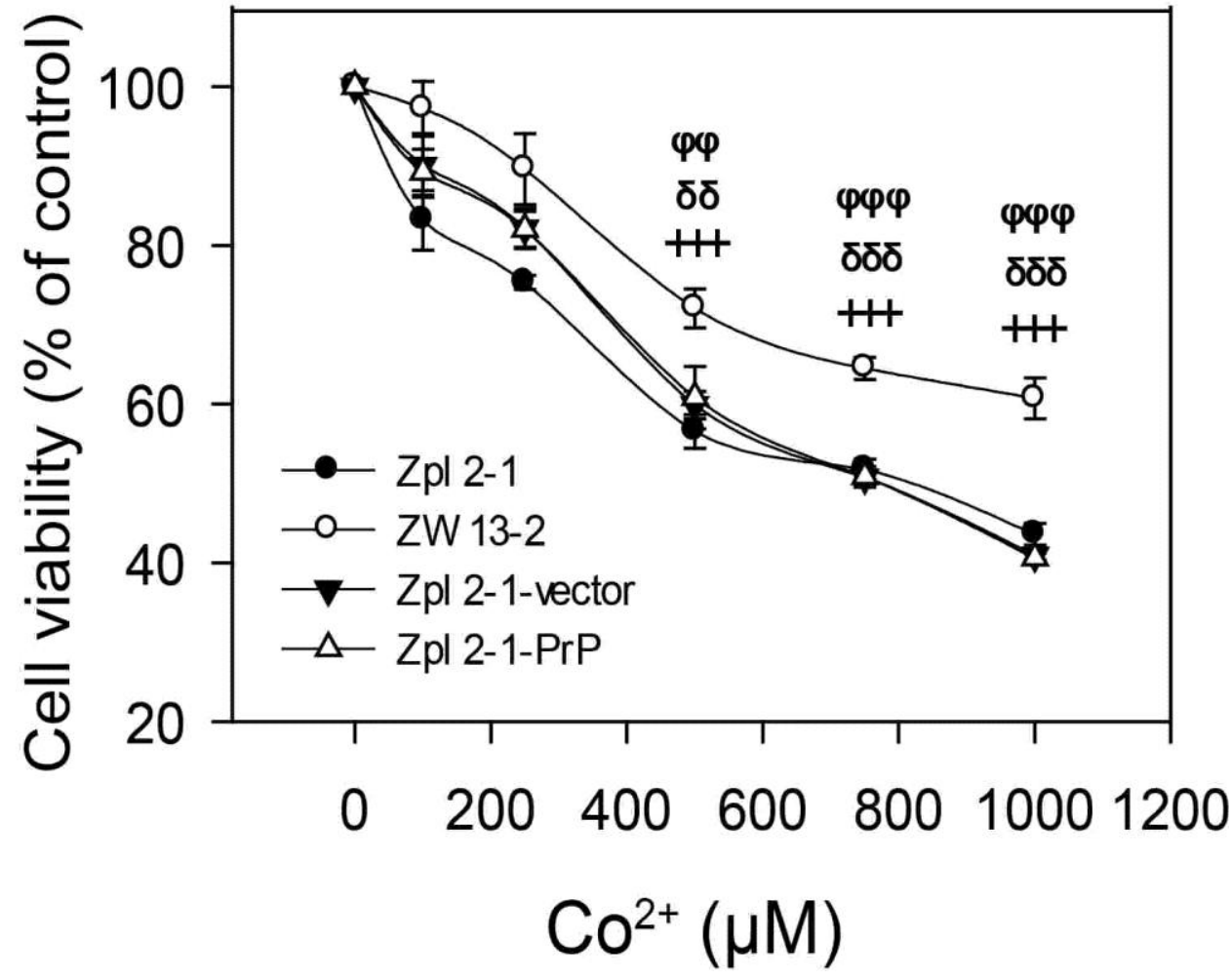


Figure 19: Effect of $\operatorname{PrP}^{\mathrm{C}}$ expression on the susceptibility of cells to $\mathrm{Cu}^{2+}, \mathrm{Zn}^{2+}, \mathrm{Mn}^{2+}$ and $\mathrm{Co}^{2+}$ induced toxicity. Cells were tested for survival after treatment with transition metals for $24 \mathrm{~h}$ and cell viability was determined using alamarBlue assay. Values are compared to those of the untreated controls and are expressed as percentage. The cell lines ZW 13-2 (open circles), Zpl 2-1 (black circles), Zpl 2-1-PrP (open triangles) and Zpl 2-1-vector (black triangles) were treated similarly with increasing concentrations of metals and all four types of cells are compared on panels A through $\mathrm{D}$, as follows: increasing concentration of $\mathrm{Cu}^{2+}$-Gly (A), of $\mathrm{Zn}^{2+}(\mathrm{B}), \mathrm{Mn}^{2+}(\mathrm{C})$ and of $\mathrm{Co}^{2+}(\mathrm{D})$. The data are presented as means \pm standard deviation (S.D.) of minimum 3 independent experiments performed in 5 replicates. ${ }^{+} \mathrm{p}<0.05,{ }^{++} \mathrm{p}<0.01$ and ${ }^{+++} \mathrm{p}<0.001$ indicate significant differences between the treated ZW 13-2 cells and treated Zpl 2-1 cells; ${ }^{\delta} \mathrm{p}<0.05,{ }^{\delta \delta} \mathrm{p}<0.01$ and ${ }^{\delta \delta \delta} \mathrm{p}<0.001$ indicate significant differences between the treated ZW 13-2 cells and treated Zpl 2-1-vector cells, and ${ }^{\varphi} \mathrm{p}<0.05,{ }^{\varphi \varphi} \mathrm{p}<0.01$ and ${ }^{\varphi \varphi \varphi} \mathrm{p}<0.001$ indicate significant differences between the treated $\mathrm{ZW}$ 13-2 cells and treated Zpl 2-1-PrP cells.

Figure 19 also shows the estimated significances of the differences when making three kinds of comparisons: ZW 13-2 cells compared to Zpl 2-1 vector, Zpl 2-1-PrP, and Zpl 2-1 cells. Overall we can observe that the viability of Zpl 2-1-PrP and Zpl 2-1-vector cells are significantly lower than that of $\mathrm{ZW} 13-2$ cells in case of $\mathrm{Cu}^{+2}, \mathrm{Zn}^{+2}$ and $\mathrm{Co}^{+2}$ treatment (Figure 19A, B and D), whereas no significant difference is observed in case of $\mathrm{Mn}^{+2}$ treatment (Figure $19 \mathrm{C}$ ).

Given that the PrP expression levels of the two cell lines, ZW 13-2 and Zpl 2-1-PrP, are comparable these findings argue that PrP was not the sole reason for the increased resistance of ZW 13-2 cells compared to Zpl 2-1 cells when exposed to metal stresses.

\subsection{Zpl 2-1-PrP cells are not less affected morphologically by $\mathrm{Cu}^{2+}, \mathrm{Zn}^{2+}, \mathrm{Mn}^{2+}$ and $\mathrm{Co}^{2+}$ induced stresses than its control $\mathrm{Zpl} 2-$}

\section{1-vector cells}


Subsequently, we tested whether the generated stable cell lines differed in their morphological features when exposed to different doses of $\mathrm{Cu}^{2+}, \mathrm{Zn}^{2+}, \mathrm{Mn}^{2+}$ and $\mathrm{Co}^{2+}$ using light microscopy (Figures 20 through 23). The morphological features of Zpl 2-1-PrP and Zpl 2-1-vector cells exposed to each of the four metals revealed irregular shrinkage and cell rounding compared to the untreated control cells. The number of cells attached to the surfaces of culture dishes gradually decreased in a dose-dependent manner for $\mathrm{Cu}^{2+}$ (Figure 20), $\mathrm{Zn}^{2+}$ (Figure 21), $\mathrm{Mn}^{2+}$ (Figure 22) and $\mathrm{Co}^{2+}$ (Figure 23) treatments, and in a similar manner for both types of cells.

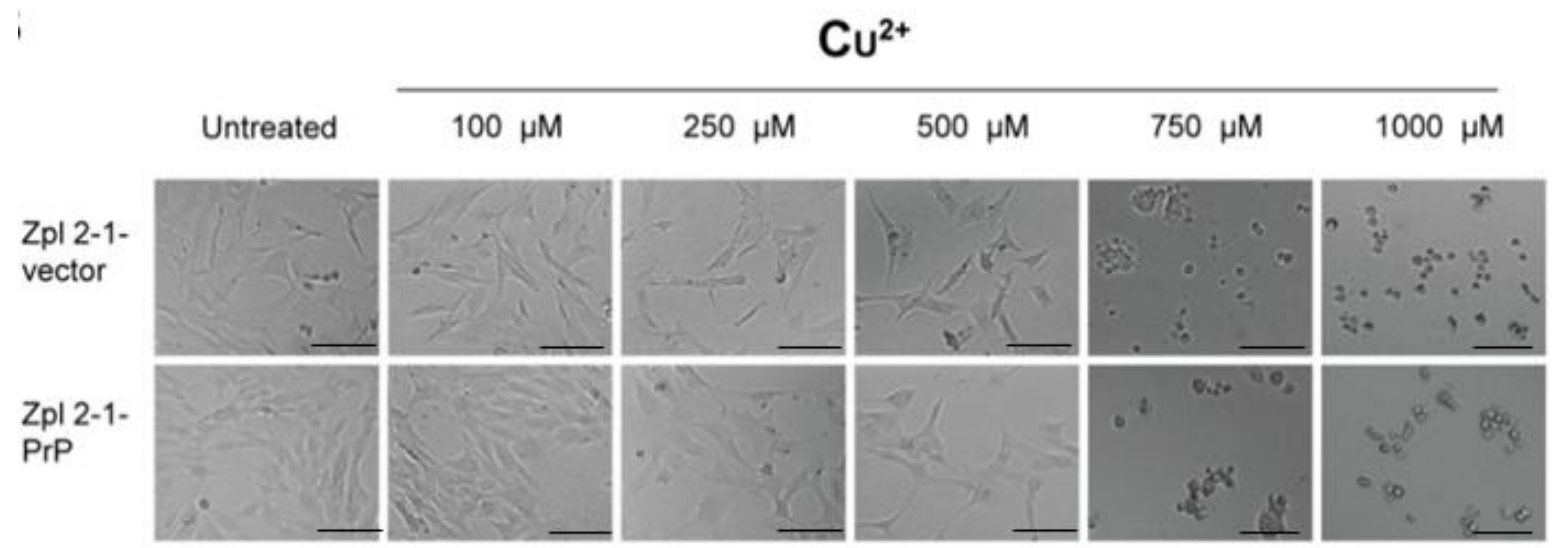

Figure 20: Morphological appearance of $\mathrm{Zpl} \mathrm{2-1-vector} \mathrm{and} \mathrm{Zpl}$ 2-1-PrP with $\mathrm{Cu}^{2+}$. $\mathrm{Zpl}$ 2-1-vector and Zpl 2-1-PrP cells, when treated with the indicated concentrations of $\mathrm{Cu}^{2+}$-Gly. Transmission light microscopy images of cells recorded using a 10X objective. Scale bar: 100 $\mu \mathrm{m}$.

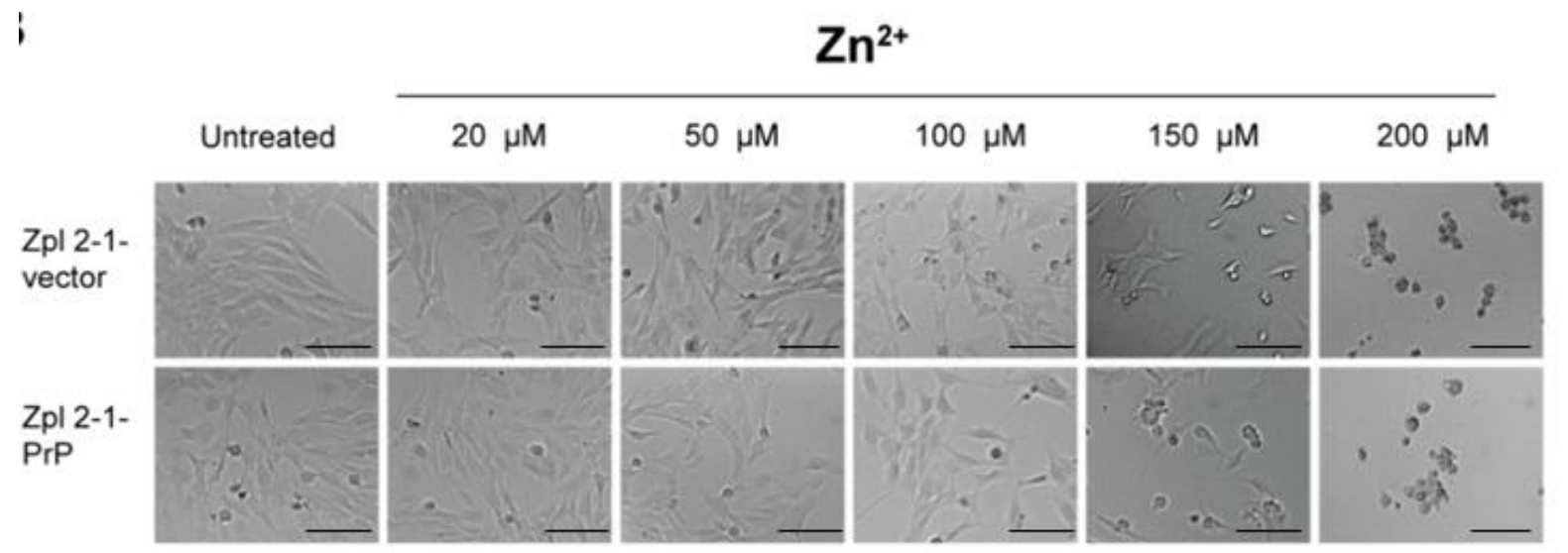

Figure 21: Morphological appearance of $\mathrm{Zpl}$ 2-1-vector and $\mathrm{Zpl}$ 2-1-PrP with $\mathrm{Zn}^{2+}$. $\mathrm{Zpl}$ 2-1-vector and $\mathrm{Zpl} 2-1-\mathrm{PrP}$ cells treated with the indicated concentrations of $\mathrm{Zn}^{2+}$. 
Transmission light microscopy images of cells, acquired using a 10X objective. Scale bar: 100 $\mu \mathrm{m}$.

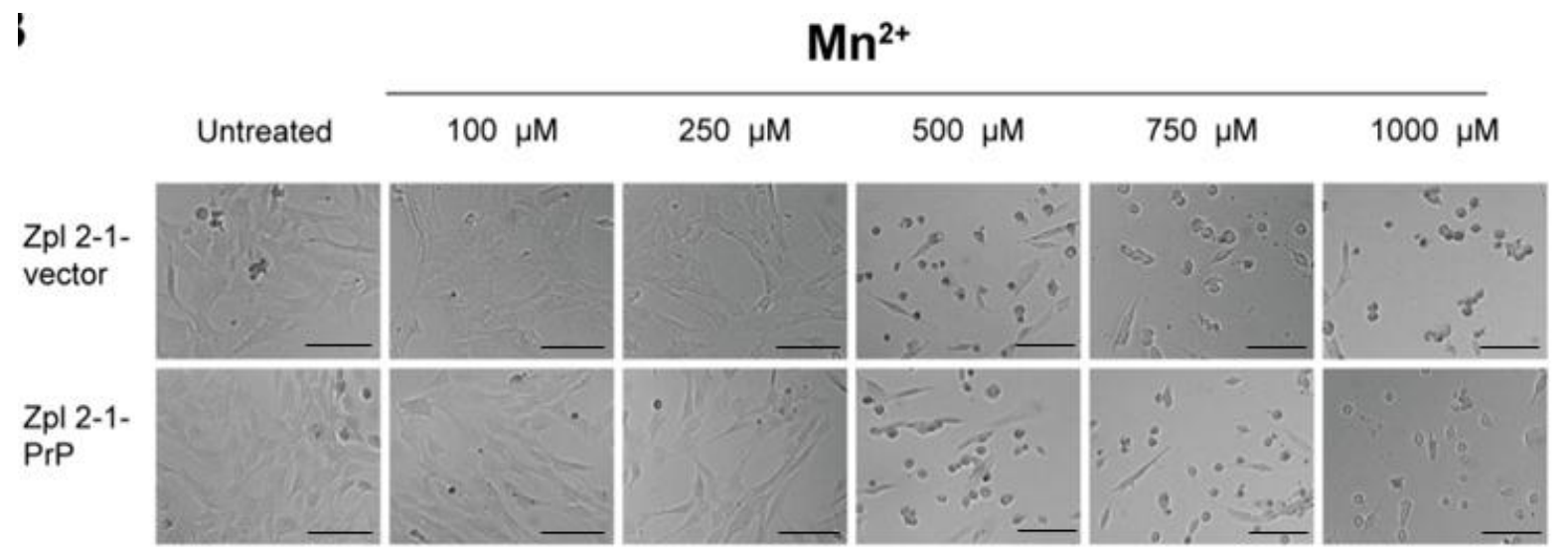

Figure 22: Morphological appearance of $\mathrm{Zpl} \mathrm{2-1-vector} \mathrm{and} \mathrm{Zpl}$ 2-1-PrP with $\mathrm{Mn}^{2+}$. $\mathrm{Zpl}$ 2-1-vector and $\mathrm{Zpl} 2-1-\mathrm{PrP}$ cells treated with the indicated concentrations of $\mathrm{Mn}^{2+}$. Transmission light microscopy images of cells acquired using a 10X objective. Scale bar: 100 $\mu \mathrm{m}$.

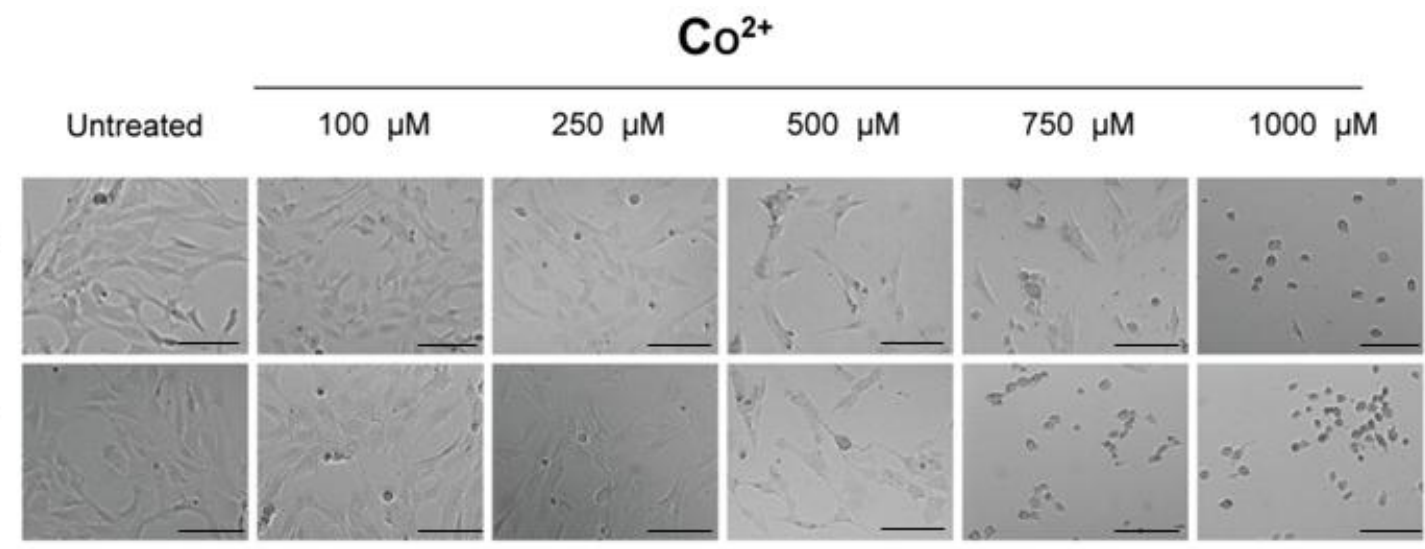

Figure 23: Morphological appearance of $\mathrm{Zpl}$ 2-1-vector and $\mathrm{Zpl}$ 2-1-PrP with $\mathrm{Co}^{2+}$. Zpl 2-1-vector and $\mathrm{Zpl} 2-1-\mathrm{PrP}$ cells treated with the indicated concentrations of $\mathrm{Co}^{2+}$. Transmission light microscopy images of cells recorded using a 10X objective. Scale bar: 100 $\mu \mathrm{m}$.

From these observations we can conclude that even though Zpl 2-1-PrP cells do express the prion protein at considerable levels, they are not significantly more resistant to $\mathrm{Cu}^{2+}, \mathrm{Zn}^{2+}, \mathrm{Mn}^{2+}$ and $\mathrm{Co}^{2+}$ induced toxicities than its control $\mathrm{Zpl}$ 2-1-vector cells based on the morphological comparisons, since they appear to be similarly affected morphologically by these metal induced stresses. 
4.6 $\mathrm{Zpl}$ 2-1-PrP cells are not more resistant to $\mathrm{Cu}^{+2}, \mathrm{Zn}^{+2}$ and $\mathrm{Co}^{+2}$ induced cell death than Zpl 2-1-vector cells, whereas, PrP expressing ZW cells are more resistant compared to the PrP ablated Zpl 2-1 cells

As a complementary approach to cell viability and cell morphological assays, we attempted to check the effect of the presence of $\operatorname{PrP}^{\mathrm{C}}$ on transition metal-toxicity by assessing the extent of cell death caused by the metal treatment. ZW 13-2, Zpl 2-1, Zpl 2-1-PrP and Zpl 2-1-vector cells were treated with the four transition metal ions $\mathrm{Cu}^{2+}, \mathrm{Zn}^{2+}, \mathrm{Mn}^{2+}$ and $\mathrm{Co}^{2+}$ for a period of $24 \mathrm{~h}$ followed by measurement of cell death using Propidium Iodide (PI) exclusion assay. Zpl 2-1, ZW 13-2, Zpl 2-1-vector and Zpl 2-1-PrP cells were treated either with $750 \mu \mathrm{M} \mathrm{Cu}^{2+}$, or with $100 \mu \mathrm{M}$ of $\mathrm{Zn}^{2+}$, or $500 \mu \mathrm{M}$ of $\mathrm{Mn}^{2+}$ or $750 \mu \mathrm{M}$ of $\mathrm{Co}^{2+}$, respectively. Dead cells were stained with PI and the histograms obtained by flow cytometry analysis were compared between the treated and untreated cells in case of each metal treatment (Figure 24A, 25A, 26A and 27A, respectively). 
A

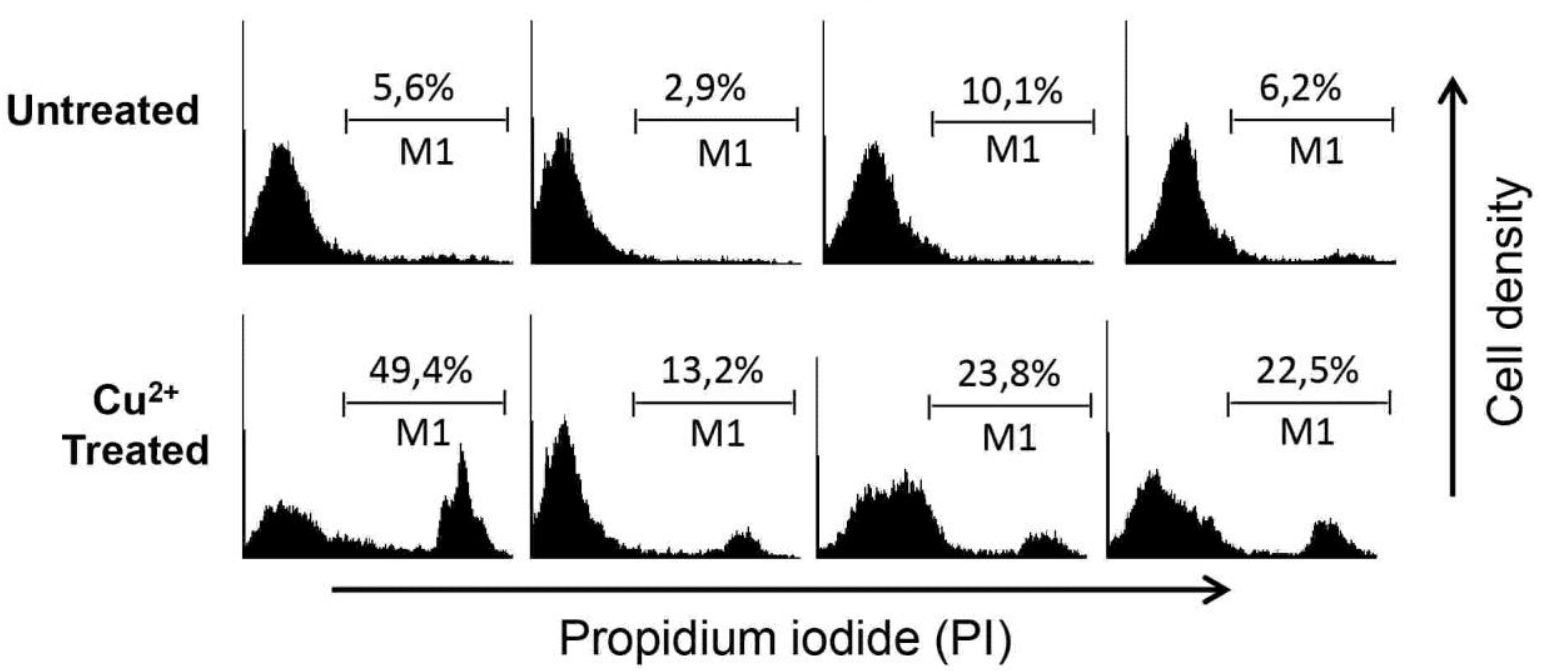

B

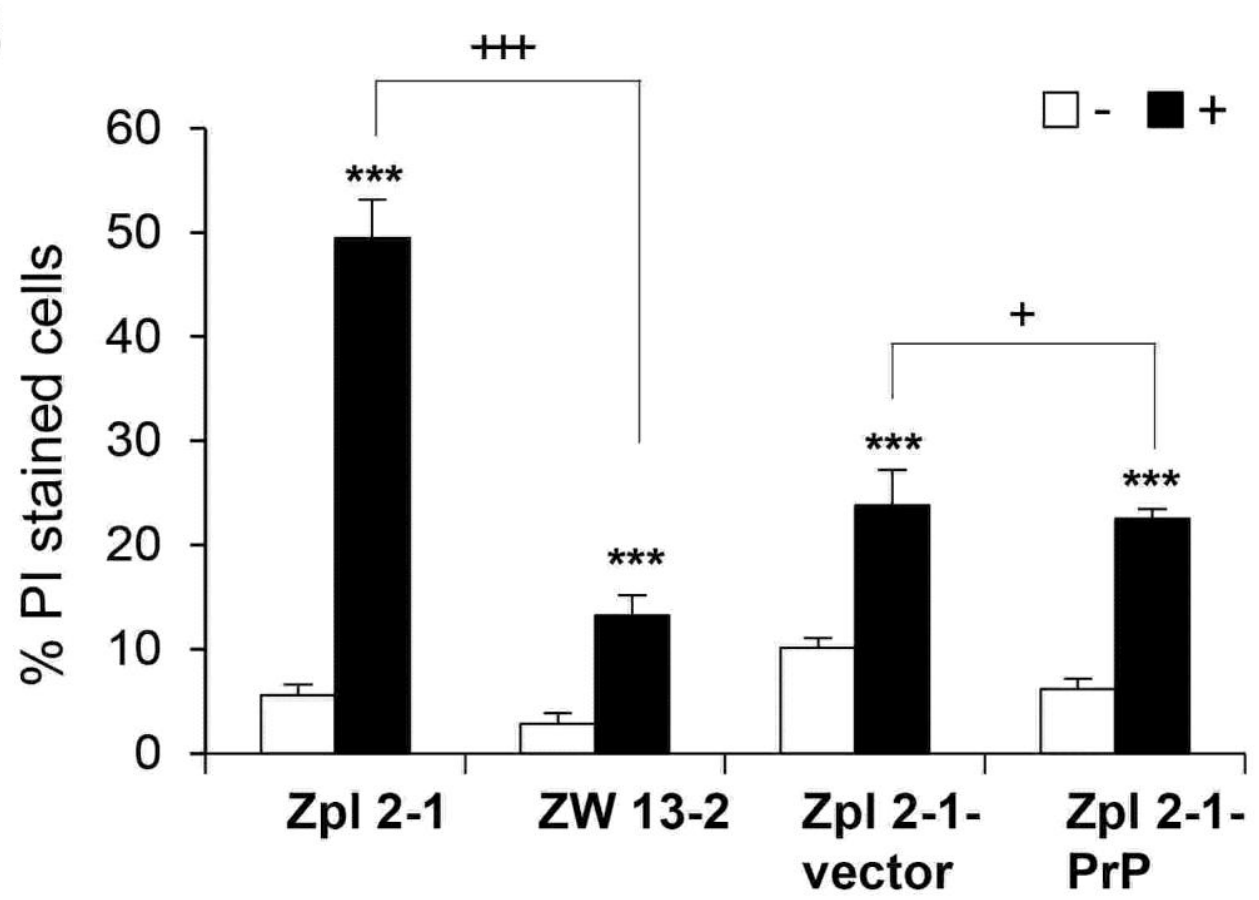

Figure 24: The effect of the presence of $\mathrm{PrP}^{\mathrm{C}}$ on $\mathrm{Cu}^{2+}$ transition metal induced cell death. Cells were tested for cell death after treatment with transition metals for $24 \mathrm{~h}$, cell death was measured by propidium iodide (PI) exclusion assay. (A) Zpl 2-1, ZW 13-2, Zpl 2-1-vector and $\mathrm{Zpl} 2$ 2-1-PrP cells were treated with $750 \mu \mathrm{M}$ of $\mathrm{Cu}^{2+}$-Gly $(1: 4 \mathrm{~mol} / \mathrm{mol}$. Dead cells were stained with PI and histograms were obtained by flow cytometric analysis. M1 represents the population of PI positive cells. The bar graphs on the panel indicate the average of PI positive cells in case of $750 \mu \mathrm{M}$ of $\mathrm{Cu}^{2+}$ treatment (B). Experiments were performed three times in duplicates, and data represent the mean \pm standard deviation (S.D.). ${ }^{*} p<0.05,{ }^{*} p<0.01$ and $* * * p<0.001$ indicate significant differences between treated (+) and untreated (-) 
cells; ${ }^{+} \mathrm{p}<0.05,{ }^{++} \mathrm{p}<0.01$ and ${ }^{+++} \mathrm{p}<0.001$ indicate significant differences between the ratios obtained for treated ZW 13-2 cells to treated Zpl 2-1 cells, and treated Zpl 2-1-vector cells to treated Zpl 2-1-PrP cells, respectively.

Exposure to $\mathrm{Cu}^{2+}, \mathrm{Zn}^{2+}$, and $\mathrm{Mn}^{2+}$ for $24 \mathrm{~h}$ resulted in increase of PI positive cells in most cell lines and conditions as shown by the average number of PI stained dead cells on the B panels of the figures 24 through 26 (Figure 24B, 25B and 26B. However, the number of PI positive cells was significantly less in ZW 13-2 as compared to Zpl 2-1 cell lines in case of $\mathrm{Cu}^{2+}, \mathrm{Zn}^{2+}$ and $\mathrm{Mn}^{2+}$ (Figure 24B, 25B and 26B) but not in case of $\mathrm{Co}^{2+}$ treatments.

A

Zpl 2-1

ZW 13-2

Zpl 2-1-vector

Zpl 2-1-PrP

Untreated
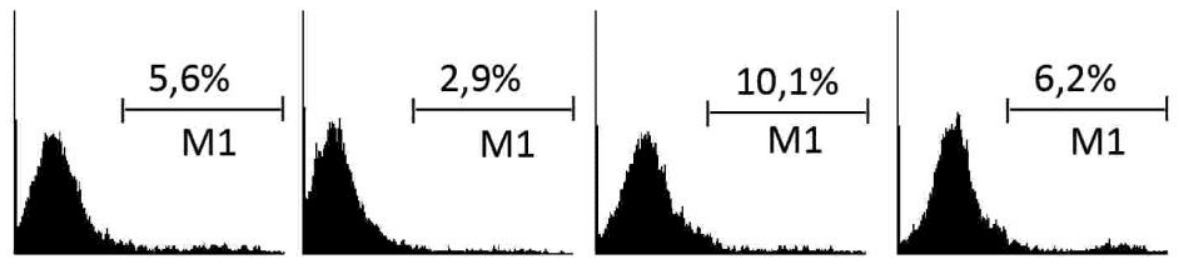

$\mathrm{Zn}^{2+}$

Treated
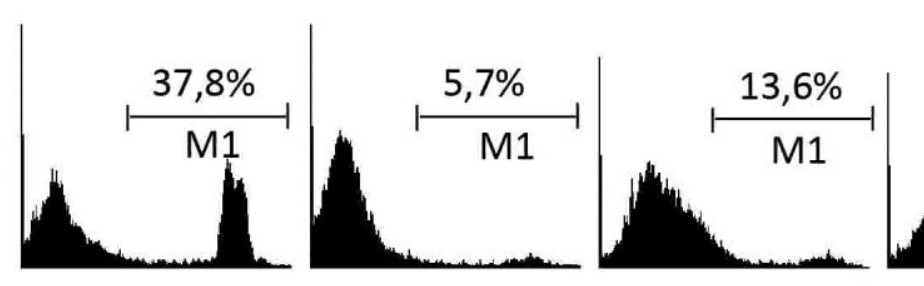

$47,6 \%$

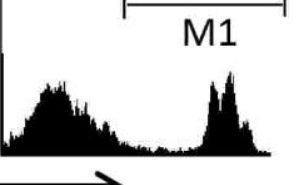

Propidium iodide (PI) 


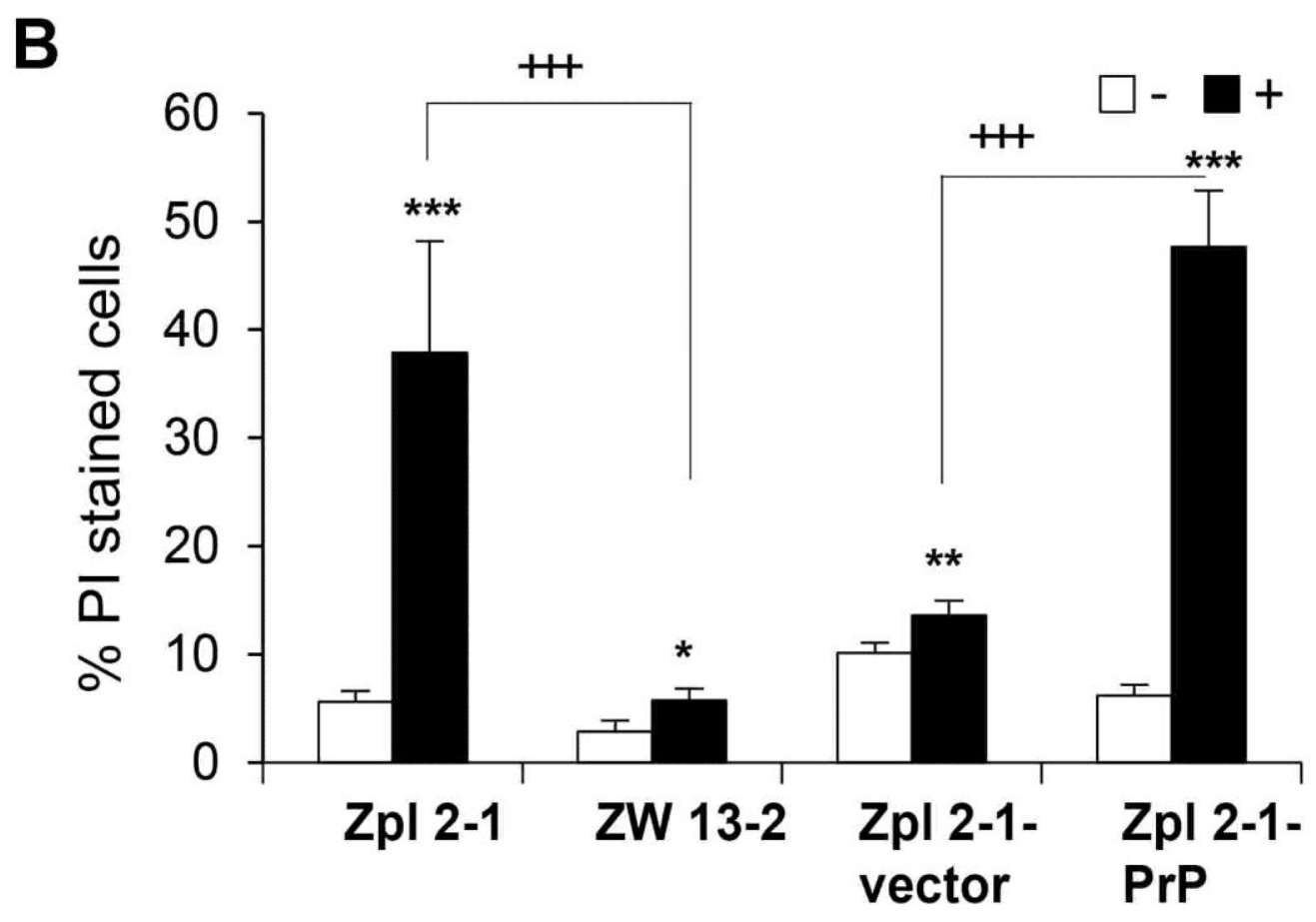

Figure 25: The effect of the presence of $\operatorname{PrP}^{\mathrm{C}}$ on $\mathrm{Zn}^{2+}$ transition metal induced cell death. Cells were tested for cell death after treatment with transition metals for $24 \mathrm{~h}$, cell death was measured by propidium iodide (PI) exclusion assay. (A) Zpl 2-1, ZW 13-2, Zpl 2-1-vector and $\mathrm{Zpl} 2-1$-PrP cells were treated with with $100 \mu \mathrm{M}$ of $\mathrm{Zn}^{2}$. Dead cells were stained with PI, and histograms were obtained by flow cytometric analysis. M1 represents the population of PI positive cells. The bar graphs on the panel indicate the average of PI positive cells in case of $100 \mu \mathrm{M}$ of $\mathrm{Zn}^{2+}$ treatment (B). Experiments were performed three times in duplicates, and data represent the mean \pm standard deviation (S.D.). $* \mathrm{p}<0.05, * * \mathrm{p}<0.01$ and $* * * \mathrm{p}<0.001$ indicate significant differences between treated $(+)$ and untreated (-) cells; ${ }^{+} \mathrm{p}<0.05,{ }^{++} \mathrm{p}<0.01$ and ${ }^{+++} \mathrm{p}<0.001$ indicate significant differences between the ratios obtained for treated $\mathrm{ZW}$ 13-2 cells to treated Zpl 2-1 cells, and treated Zpl 2-1-vector cells to treated Zpl 2-1-PrP cells, respectively.

$\mathrm{Co}^{2+}$ was not significantly toxic to either $\mathrm{Zpl} 2-1$ or $\mathrm{ZW} 13-2$ cells compared to untreated control cells (Figure 27B). In case of Zpl 2-1-vector and Zpl 2-1-PrP cells, however, such results could not be observed; the $\mathrm{Zpl} 2$-1-PrP cell population had significantly more PI positive cells compared to $\mathrm{Zpl} 2-1$-vector cells when treated by $\mathrm{Cu}^{2+}, \mathrm{Zn}^{2+}$ and $\mathrm{Co}^{2+}$ (Figure 24B, 25B and 27B), with both cell lines being unresponsive to manganese treatment. 
A Zpl 2-1

ZW 13-2

Zpl 2-1-vector

Zpl 2-1-PrP

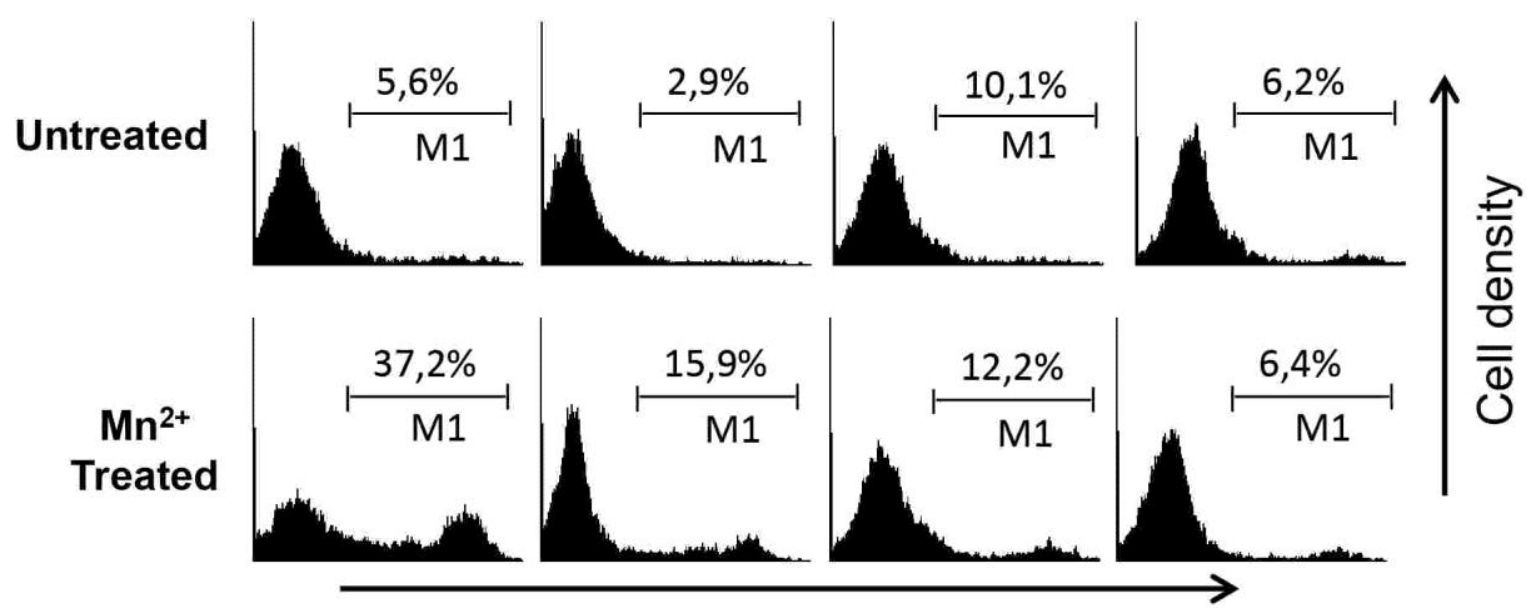

Propidium iodide (PI)

B

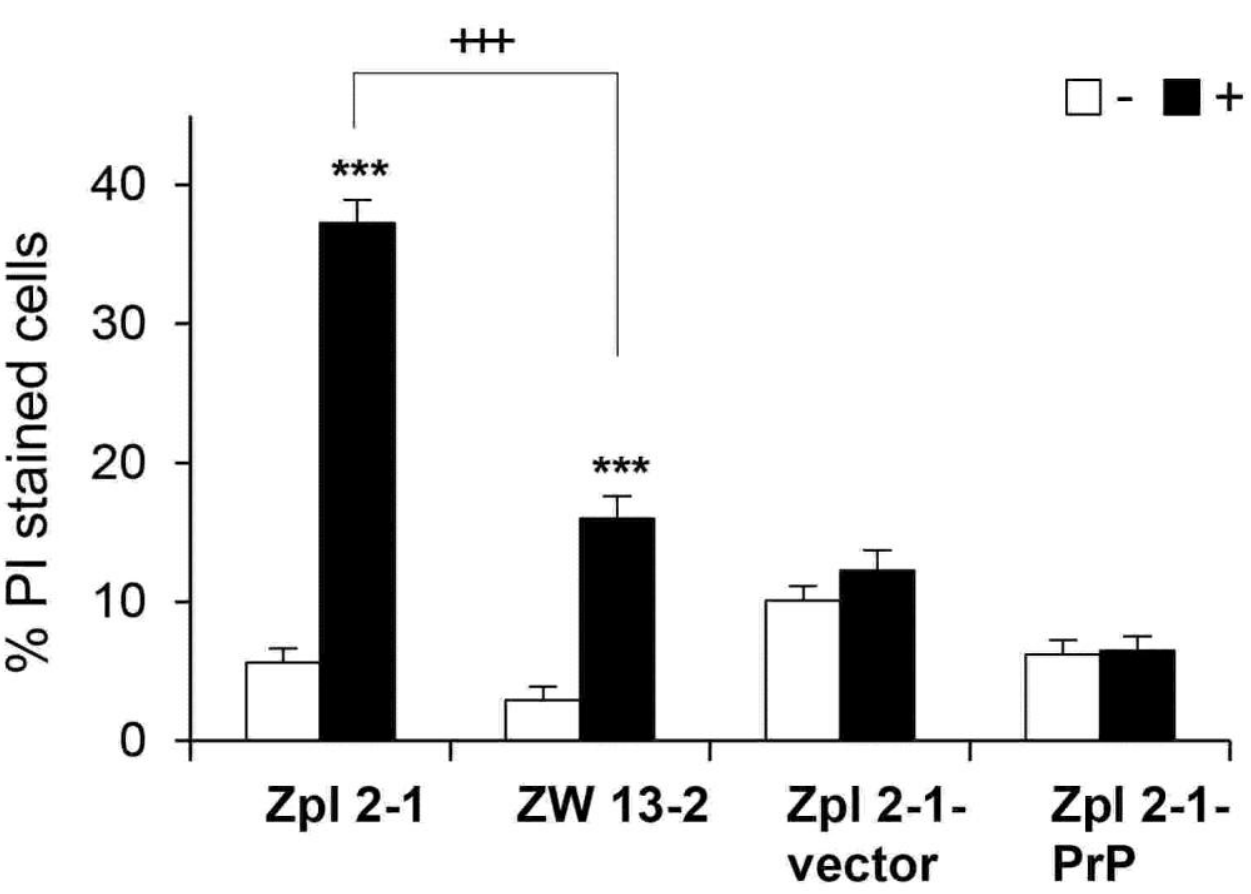

Figure 26: The effect of the presence of $\operatorname{PrP}^{\mathrm{C}}$ on $\mathrm{Mn}^{2+}$ transition metal induced cell death. Cells were tested for cell death after treatment with transition metals for $24 \mathrm{~h}$, cell death was measured by propidium iodide (PI) exclusion assay. (A) Zpl 2-1, ZW 13-2, Zpl 21-vector and $\mathrm{Zpl} 2$ 2-1-PrP cells were treated with $500 \mu \mathrm{M}$ of $\mathrm{Mn}^{2+}$. Dead cells were stained with PI, and histograms were obtained by flow cytometric analysis. M1 represents the population of PI positive cells. The bar graphs on the panel indicate the average of PI positive cells in case of $500 \mu \mathrm{M}$ of $\mathrm{Mn}^{2+}$ treatment (B). Experiments were performed three times in duplicates, and data represent the mean \pm standard deviation (S.D.). ${ }^{*} \mathrm{p}<0.05, * * \mathrm{p}<0.01$ and $* * * \mathrm{p}<0.001$ indicate significant differences between treated $(+)$ and untreated (-) cells; ${ }^{+} \mathrm{p}<0.05,{ }^{++} \mathrm{p}<0.01$ and ${ }^{+++} \mathrm{p}<0.001$ indicate significant differences between the ratios 
obtained for treated ZW 13-2 cells to treated Zpl 2-1 cells, and treated Zpl 2-1-vector cells to treated Zpl 2-1-PrP cells, respectively.

These data indicate that $\operatorname{PrP}^{\mathrm{C}}$-expressing $\mathrm{Zpl}$ 2-1-PrP cells did not gain more resistance to any of the metals tested and at the concentrations applied, compared to PrPlacking Zpl 2-1-vector cells.

A
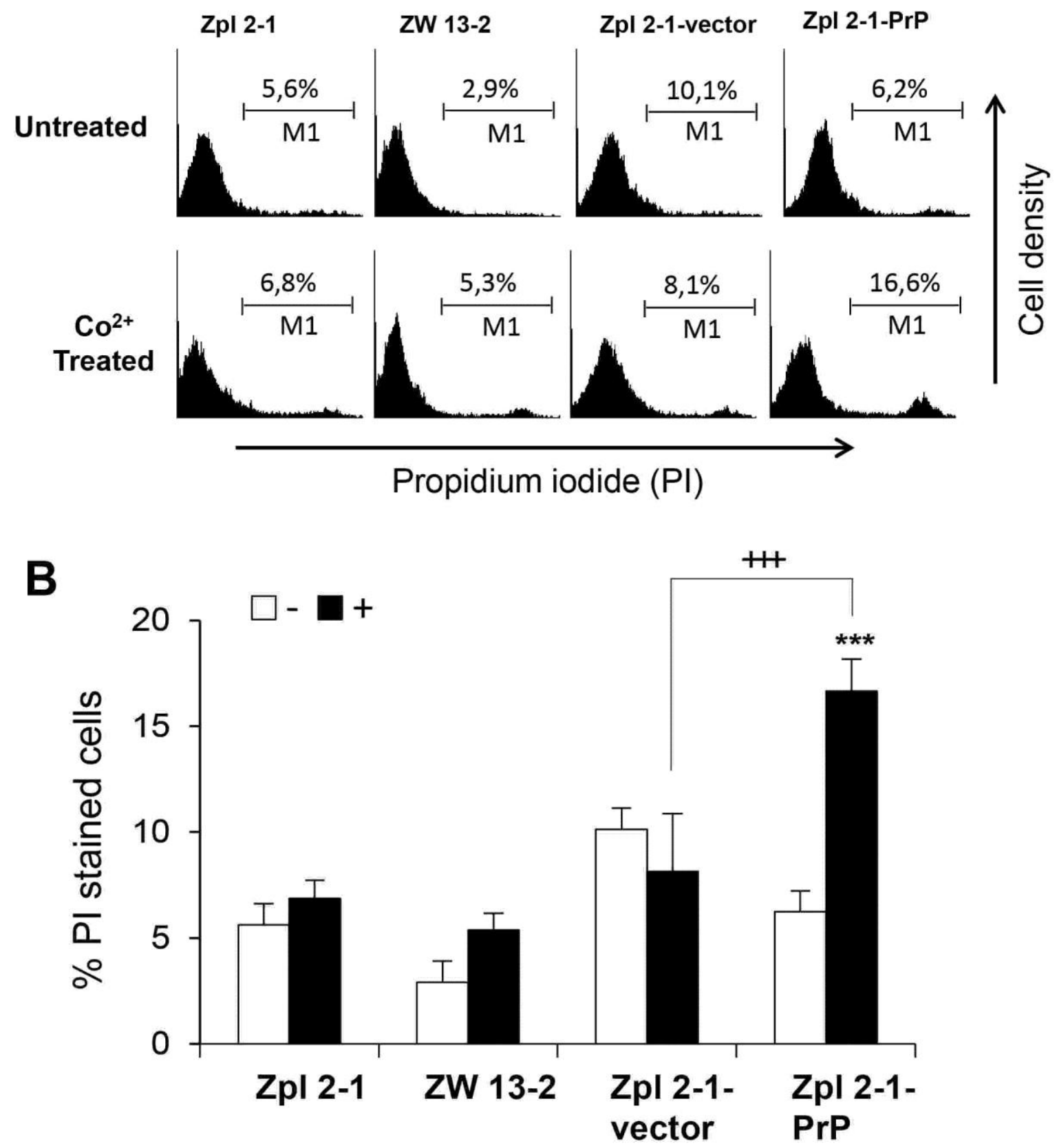

Figure 27: The effect of the presence of $\mathrm{PrP}^{\mathrm{C}}$ on $\mathrm{Co}^{2+}$ transition metal induced cell death. 
Cells were tested for cell death after treatment with transition metals for $24 \mathrm{~h}$, cell death was measured by propidium iodide (PI) exclusion assay. (A) Zpl 2-1, ZW 13-2, Zpl 2-1-vector and $\mathrm{Zpl} 2-1-\mathrm{PrP}$ cells were treated with $750 \mu \mathrm{M}$ of $\mathrm{Co}^{2+}$. Dead cells were stained with PI, and histograms were obtained by flow cytometric analysis. M1 represents the population of PI positive cells. The bar graphs on the panel indicate the average of PI positive cells in case of $750 \mu \mathrm{M}$ of $\mathrm{Co}^{2+}$ treatment (B). Experiments were performed three times in duplicates, and data represent the mean \pm standard deviation (S.D.). $* \mathrm{p}<0.05,{ }^{*} \mathrm{p}<<0.01$ and $* * * \mathrm{p}<0.001$ indicate significant differences between treated (+) and untreated (-) cells; ${ }^{+} \mathrm{p}<0.05,{ }^{++} \mathrm{p}<0.01$ and ${ }^{+++} \mathrm{p}<0.001$ indicate significant differences between the ratios obtained for treated $\mathrm{ZW}$ 13-2 cells to treated Zpl 2-1 cells, and treated Zpl 2-1-vector cells to treated Zpl 2-1-PrP cells, respectively.

From these observations we can conclude that the PrP expressing Zpl 2-1-PrP cells are not more resistant to $\mathrm{Cu}^{+2}, \mathrm{Zn}^{+2}$ and $\mathrm{Co}^{+2}$ induced cell death than $\mathrm{Zpl}$ 2-1-vector cells when assessing by propidium iodide (PI) exclusion cell death assay, whereas the PrP expressing wild type $\mathrm{ZW}$ cells prove to be more resistant to $\mathrm{Cu}^{2+}, \mathrm{Zn}^{2+}$ and $\mathrm{Mn}^{2+}$ treatments, but not $\mathrm{Co}^{+2}$ treatment.

\subsection{SH-SY5Y-PrP cells are significantly more resistant to $\mathrm{Cu}^{2+}$} and $\mathrm{Mn}^{2+}$ induced toxicities than SH-SY5Y and SH-SY5Y-vector cells

In order to test the generality of the observation made using Zpl cells, namely that expression of $\operatorname{PrP}$ in itself did not restore or increase the resistance of the cells to transition metals' toxicities; we performed similar experiments on another type of cell, the SH-SY5Y neuroblastoma cell line. These cells are known to possess very low to undetectable amounts of endogenous PrP. We have transfected these cells using the SB transposase system as in the case of the Zpl cells, with an expression vector containing the mouse PrP gene and as control with the same vector but without the PrP gene and established stable expressing cell lines from both populations: SH-SY5Y-PrP and SH-SY5Y-vector cells. To test the developed 
transgenic cell lines the appropriate expression level and the proper processing of the prion protein were tested in the established cell population using immunoblot and immunocytochemical analyses (Figure 28). Total cell lysates of SH-SY5Y-PrP and SHSY5Y-vector cells were collected and immunoblotted with monoclonal PrP antibody SAF 32 (Figure 28A). The SH-SY5Y-vector cells, not expected to express $\operatorname{PrP}^{\mathrm{C}}$, show no detectable bands for PrP, whereas, the SH-SY5Y-PrP cells, exhibit a well-detectable level of $\operatorname{PrP}^{\mathrm{C}}$ expression. Expression and correct localization of the prion protein was further tested by immunocytochemical analysis (Figure 28B).

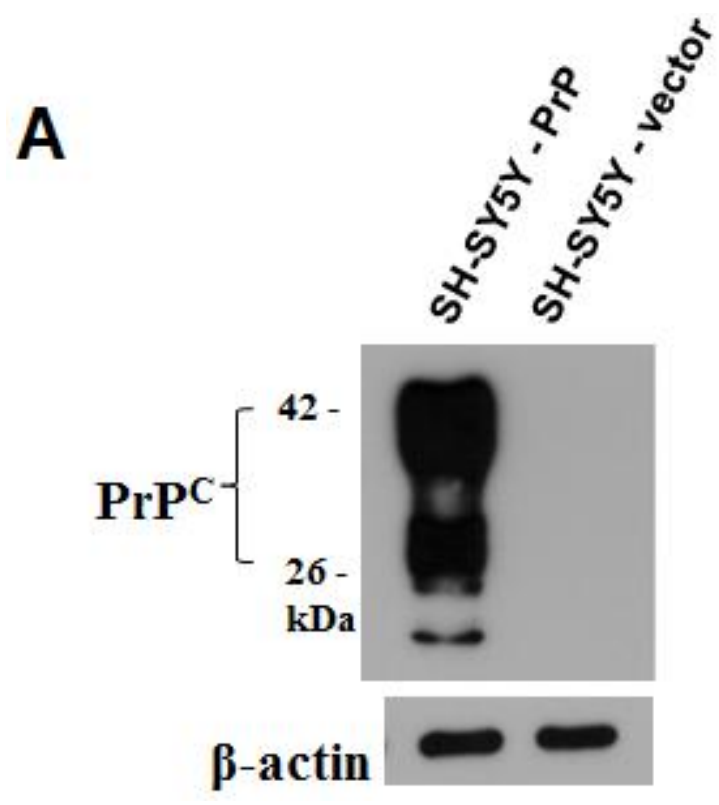




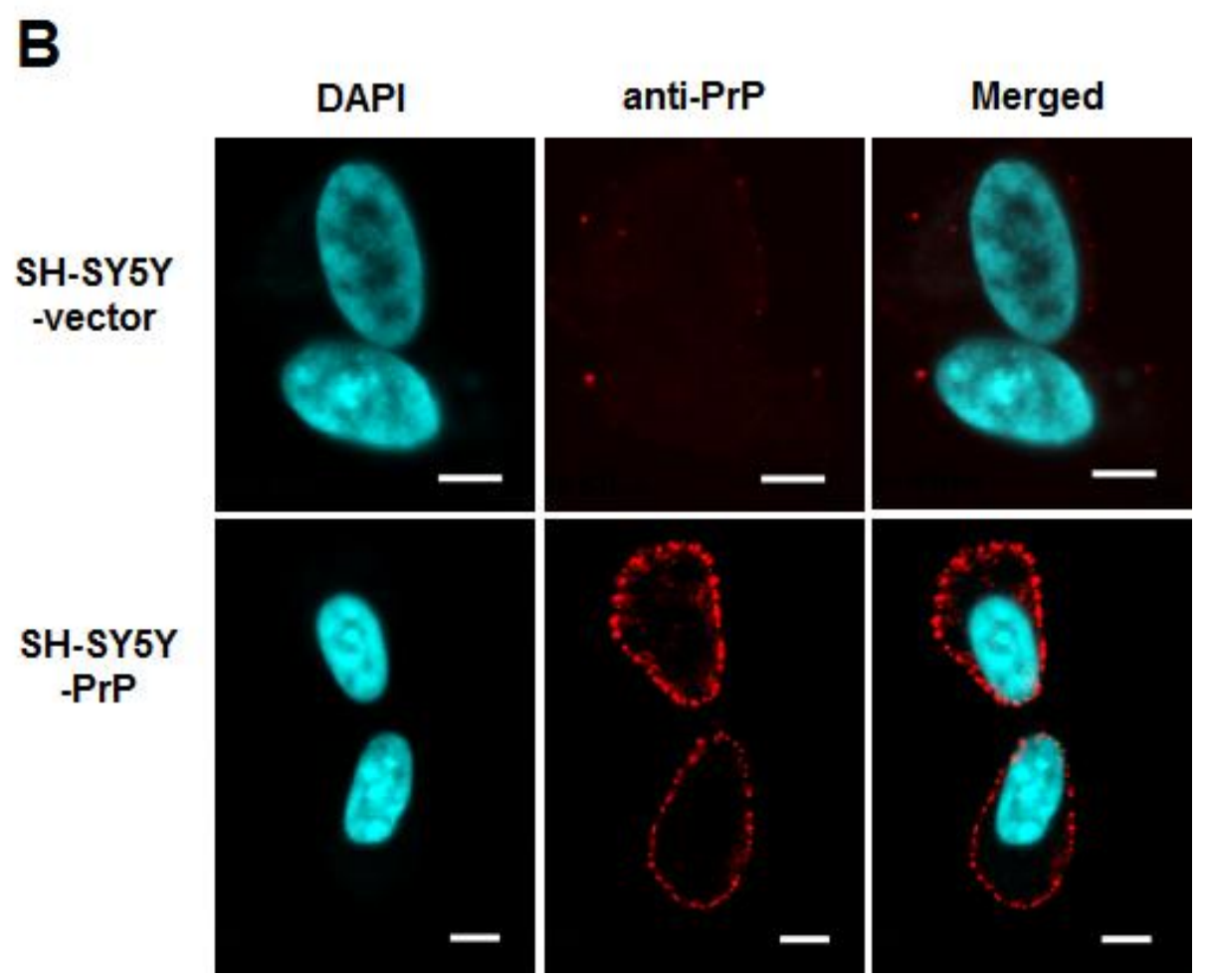

Figure 28: Prion protein expression levels in stable SH-SY5Y-vector and SH-SY5Y-PrP cell lines. (A) Western blot analysis was conducted using anti PrP antibody SAF 32 in total cell lysates from human neuroblastoma cell line (SH-SY5Y) transfected with either the empty vector (SH-SY5Y-vector) or with mouse PrP gene (SH-SY5Y-PrP). b-actin was used to confirm equal loading of proteins. (B) Immunocytochemistry was also performed to verify prion protein expression in the cells. Prion protein was stained with anti PrP antibody SAF 32 and an Alexa 568 conjugated secondary antibody (red stain). Nuclear staining was performed with DAPI (cyanine blue) and merged image is shown in the last column. Pictures were recorded using a $60 \mathrm{X}$ oil immersion objective with $4 \mathrm{X}$ zooming. Scale bar: $5 \mu \mathrm{m}$.

The bright red immunofluorescence-staining pattern in the SH-SY5Y-PrP cells revealed that the prion protein was distributed on the surface of the cells, whereas no immunoreactivity was detected in the SH-SY5Y-vector cells. For cell imaging, microscope settings and methodology were adapted from Molnar et al. (Molnár et al., 2013) similarly as in the case of the studies presented here on ZW and Zpl cells. 
These results confirmed that the established SH-SY5Y-PrP cell line expressed considerable amount of PrP with proper glycosylation and localization in the cells, whereas the control cell line, as expected, did not have detectable amounts of PrP.

To test whether there is any general protective role of $\operatorname{PrP}^{\mathrm{C}}$ against transition metalsinduced toxicity in this type of cellular model system, we aimed to assess if the three cell lines differed in sensitivity to $\mathrm{Cu}^{2+}, \mathrm{Zn}^{2+}, \mathrm{Mn}^{2+}$ or $\mathrm{Co}^{2+}$ treatments, using a range of concentrations of each metal ion and the alamarBlue-based cell viability assay, similarly as in the case of Zpl and ZW cells was used. The results obtained for each metal treatment are shown on Figure 29 as separate panels.

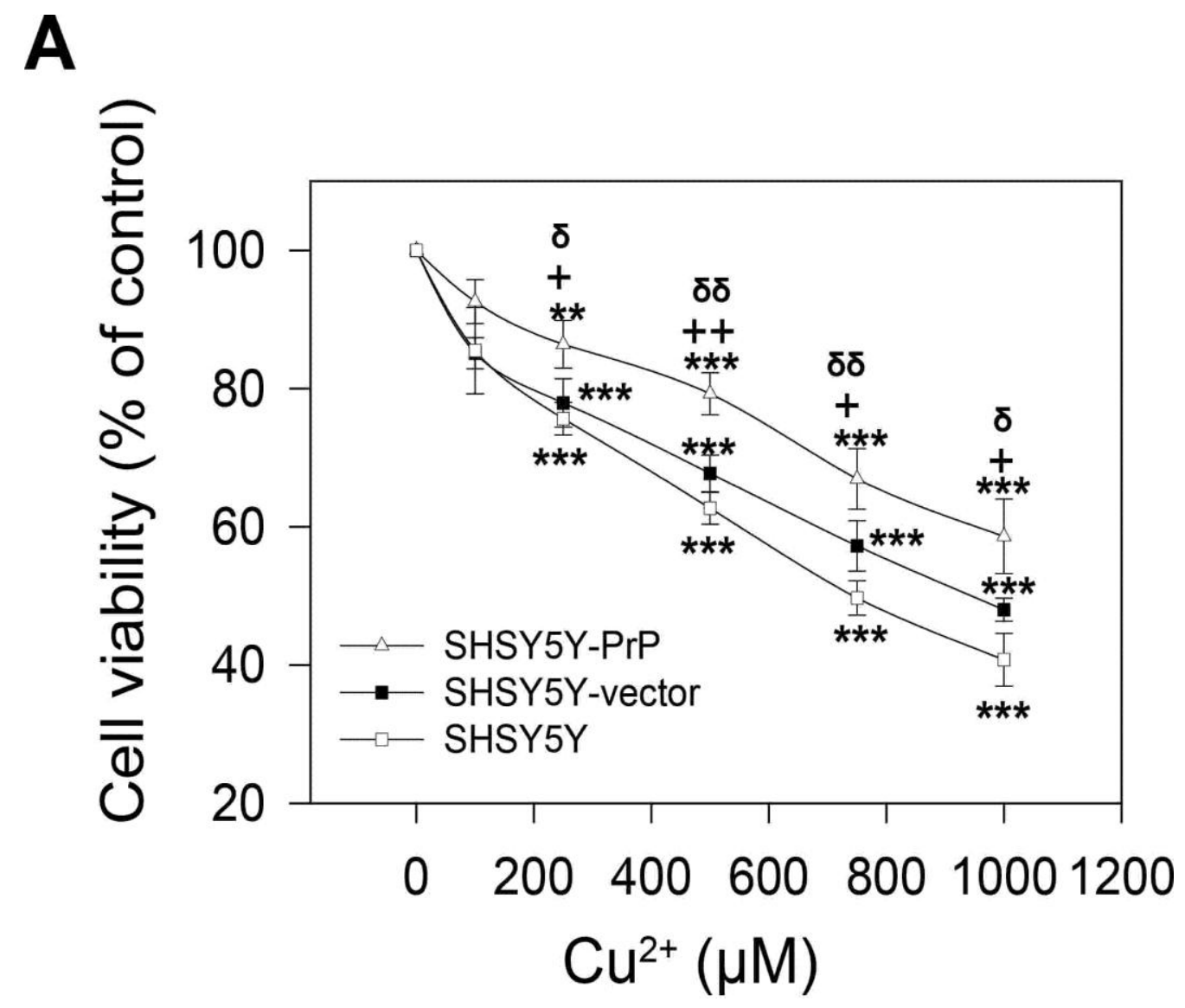


B

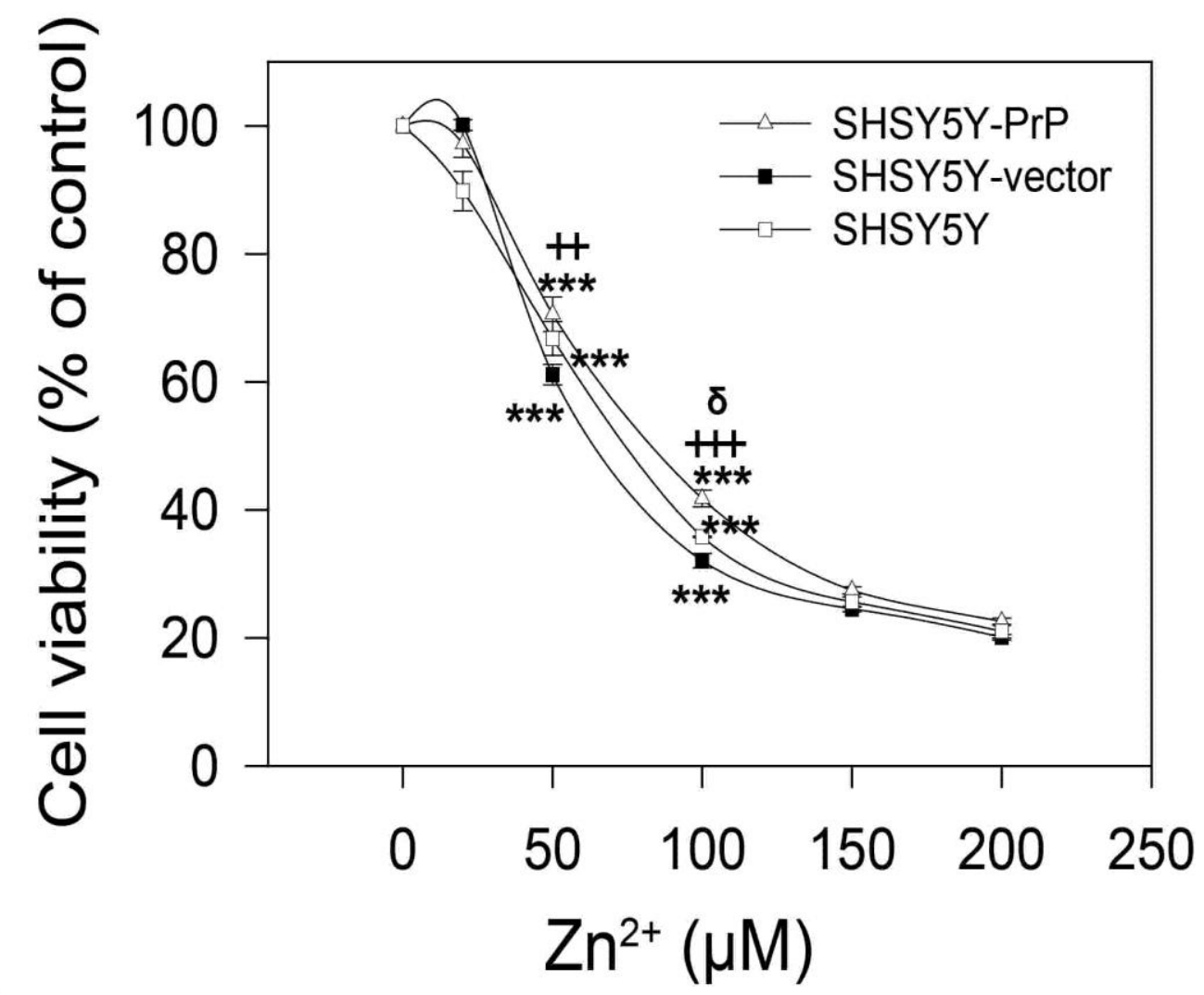

C

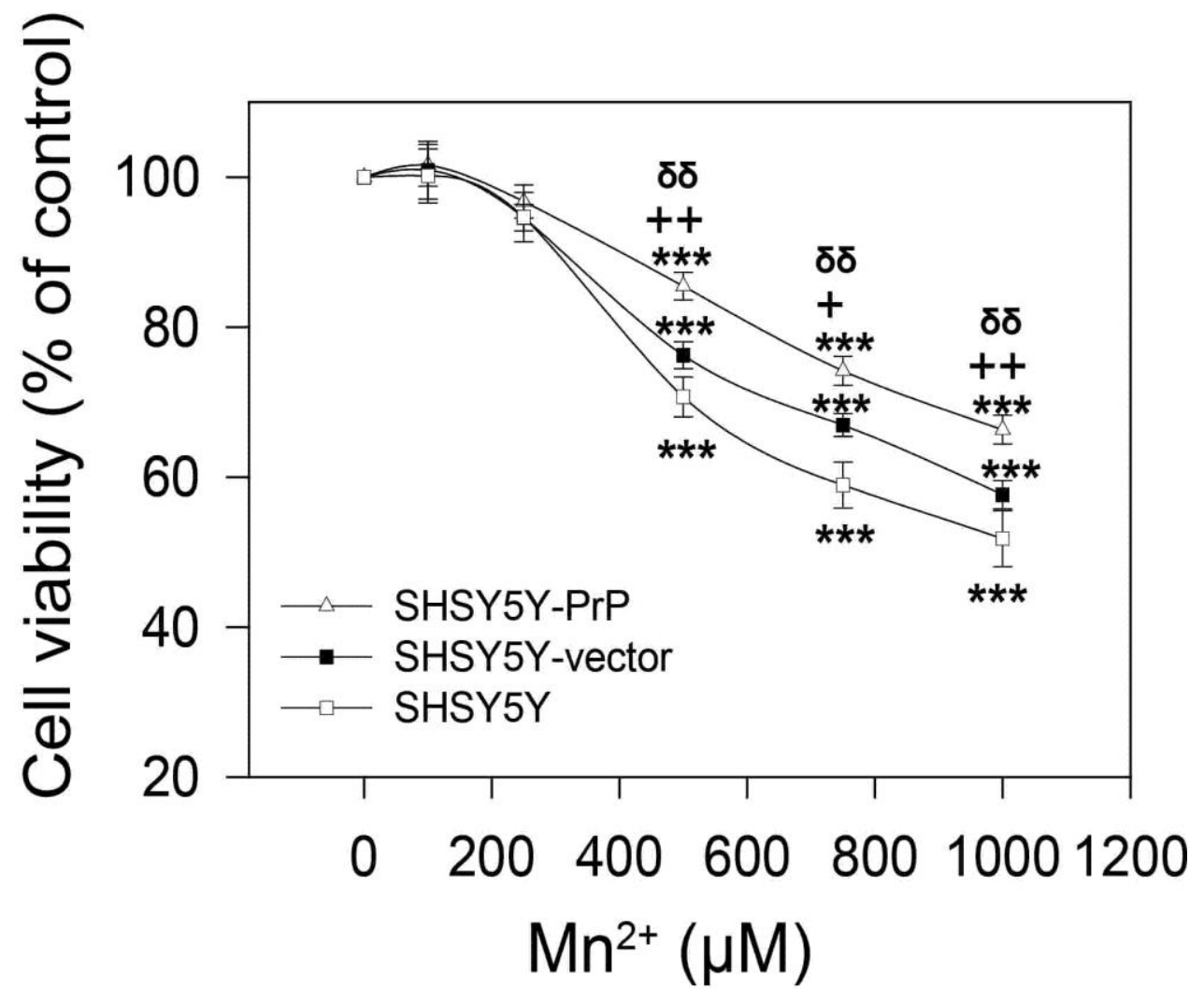




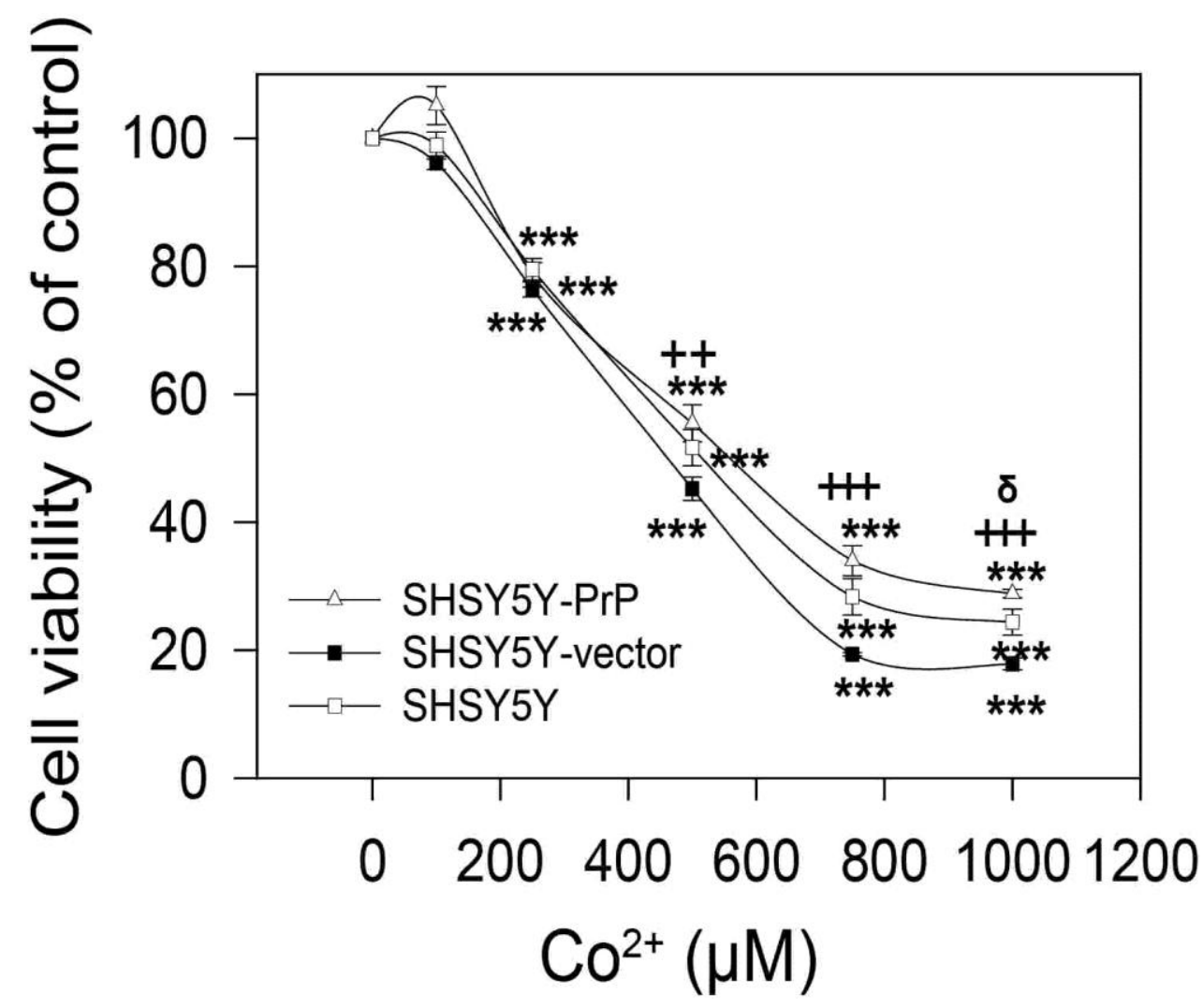

Figure 29: Effect of $\operatorname{PrP}^{\mathrm{C}}$ expression on resistance to transition metal-induced toxicity. Cells were tested for survival after treatment with transition metals for $24 \mathrm{~h}$, assessing cell viability by alamarBlue assay. The cell lines SH-SY5Y - PrP (open triangles), SH-SY5Y vector (black squares) and SH-SY5Y (open squares) were treated with increasing concentrations of either $\mathrm{Cu}^{2+}-\mathrm{Gly}(\mathrm{A})$, or $\mathrm{Zn}^{2+}(\mathrm{B})$, or $\mathrm{Mn}^{2+}(\mathrm{C})$ or $\mathrm{Co}^{2+}(\mathrm{D})$. Values were compared to those of the untreated controls and are presented as percentage. The data represent the means \pm standard deviation (S.D.) of 3 independent experiments performed in 5 replicates. $* \mathrm{p}<0.05, * * \mathrm{p}<0.01$ and $* * * \mathrm{p}<0.001$ indicate significant differences between treated and untreated cells; ${ }^{+} \mathrm{p}<0.05,{ }^{++} \mathrm{p}<0.01$ and ${ }^{+++} \mathrm{p}<0.001$ indicate significant differences between SH-SY5Y-PrP and SH-SY5Y-vector cells; ${ }^{\delta} \mathrm{p}<0.05,{ }^{\delta \delta} \mathrm{p}<0.01$ and ${ }^{\delta \delta \delta} \mathrm{p}<0.001$ indicate significant differences between SH-SY5Y-PrP and SH-SY5Y cells.

Among the four metal ions, cells proved to be least responsive to $\mathrm{Mn}^{2+}$ treatment, during which cell viability started to decrease significantly only at $500 \mu \mathrm{M}$ dose compared to untreated cells in case of the three cell lines (Figure 29C). All three cell lines are most sensitive to $\mathrm{Zn}^{2+}$ treatment showing significant differences in the number of surviving cells compared to the untreated controls at as little as $50 \mu \mathrm{M}$ dose (Figure 29B). Nevertheless, $\mathrm{SH}$ SY5Y-vector cells were significantly more susceptible to $\mathrm{Cu}^{2+}, \mathrm{Zn}^{2+}, \mathrm{Mn}^{2+}$ and $\mathrm{Co}^{2+}$ toxicities 
than SH-SY5Y-PrP cells at all concentrations of the metal ions that fall into the toxic ranges for the cells (Figure 29A through D), also, compared to the original SH-SY5Y cells they show significantly less susceptibility in case of $\mathrm{Zn}^{2+}$ and $\mathrm{Co}^{2+}$ but not $\mathrm{Cu}^{2+}$ and $\mathrm{Mn}^{2+}$ induced toxicities.

We have selected SH-SY5Y human neuroblastoma cells as another model system to investigate the role of $\operatorname{PrP}$ in metal-induced toxicity because they have very low $\operatorname{PrP}$ expression levels, and hence could serve as a "PrP-null" cell line, where the role of PrP may be studied if generating PrP-expressing transgenic line from it and comparing the behavior of the cells to the control population during stress conditions. When we generated PrPexpressing and control vector-only-expressing cell lines from these cells, we found that $\operatorname{PrP}$ expressing SH-SY5Y-PrP cells are in general significantly more resistant to $\mathrm{Cu}^{2+}, \mathrm{Zn}^{2+}$ and $\mathrm{Mn}^{2+}$ induced toxicities, than SH-SY5Y-vector cells or SH-SY5Y cells. These results seem to argue for a protective role of PrP against metal induced toxicities in this SH-SY5Y cell type based cellular model system. 


\section{Discussion}

Oxidative stress and programmed cell death have been implicated in a number of neurodegenerative disorders including prion disease (Choi et al., 2006; Kanthasamy et al., 2003; Tritschler et al., 1994). It has been known that there is a certain affinity of several transition metals towards $\operatorname{PrP}^{\mathrm{C}}$ and that the transition metal- $\operatorname{PrP}^{\mathrm{C}}$ interaction might have an effect on $\operatorname{PrP}^{\mathrm{C}}$ biology. It has been theorized that the binding of certain transition metals such as $\mathrm{Cu}^{2+}$ and $\mathrm{Zn}^{2+}$ to $\operatorname{PrP}^{\mathrm{C}}$ induces the endocytosis of the latter, which might be a signal triggering antioxidative defense. Nevertheless, although the mechanism is not clear, a protective role against toxicity conferred by transition metal ions has been suggested for the prion protein in cell culture model systems (Choi et al., 2007; Haigh and Brown, 2006; Rachidi et al., 2009). In the present study, we explored a Prnp $^{-/-}$neuronal cell line (Zpl 2-1) of hippocampal origin as a model system, along with its PrP expressing control ZW 13-2 cells. Zpl $2-1$ has been shown to be more vulnerable to serum deprivation and oxidative damage induced by $\mathrm{H}_{2} \mathrm{O}_{2}$ than its PrP-expressing counterpart (Kim et al., 2004; Oh et al., 2008, 2012). Reintroduction of PrP restored the viability of Zpl cells, thus, it seems to be a relevant model for assessing the effect of $\operatorname{PrP}^{\mathrm{C}}$ on metal-induced toxicity as well. Hence, we studied whether PrP has any general protective effect against transition metal toxicity, testing $\mathrm{Cu}^{2+}, \mathrm{Zn}^{2+}, \mathrm{Mn}^{2+}$ and $\mathrm{Co}^{2+}$ toxicities.

Metals might exert their toxic effects via multiple routes and $\operatorname{PrP}^{\mathrm{C}}$ has been reported to interfere with a handful of pathways leading to cell death (Bounhar et al., 2001; Khosravani et al., 2008; Lee et al., 2001b; McLennan et al., 2004; Vassallo and Herms, 2003).Therefore we chose methods such as alamarBlue viability assay and propidium iodide-based dye exclusion assay to examine the viability of the cells by the application of various concentrations of the four transition metals, rather than considering the mechanisms of protective pathways. 
The alamarBlue is a cell viability assay reagent which contains the cell permeable, non-toxic and weakly fluorescent blue indicator dye resazurin, which is used as an oxidation-reduction (REDOX) indicator in response to cellular metabolic reduction. AlamarBlue can be reduced by FMNH2, FADH2, NADH, NADPH and cytochromes and hence is an redox indicator for cell proliferation and viability studies because it does not interfere in any way with the reactions of the electron transport chain (Rampersad, 2012). By contrast, the nucleic acid staining dye propidium iodide, cannot pass through a viable cell membrane. It reaches the nucleus by passing through disordered areas of dead cell membranes.

According to the results presented here, PrP-expressing ZW cells are found to be more resistant to all four transition metals than PrP-ablated $\mathrm{Zpl}$ cells. These results suggest that $\operatorname{PrP}$ has a protective role against metal induced toxicity not only against $\mathrm{Cu}^{2+}, \mathrm{Mn}^{2+}$ and $\mathrm{Zn}^{2+}$ but also against $\mathrm{Co}^{2+}$ for which such role has not been reported (Haigh and Brown, 2006; Rachidi et al., 2009).

Interestingly, we found quite surprising results while establishing more define link between PrP-expression and vulnerability to transition metal induced toxicity. $\operatorname{PrP}$ reintroduction in $\mathrm{Zpl}$ cells failed to give any significant increase in resistance against $\mathrm{Cu}^{2+}$, $\mathrm{Mn}^{2+}, \mathrm{Zn}^{2+}$ and $\mathrm{Co}^{2+}$ induced toxicities by all three approaches. Hence, in the presence of metal toxicity, we could not find a clear link between the prion protein expression and a decreased sensitivity. These are interesting results, since, PrP has been reported to protect cells from copper (Haigh and Brown, 2006), manganese (Choi et al., 2007) or zinc (Rachidi et al., 2009) metal toxicity by using other cell model systems and approaches. Most of the studies concerning $\mathrm{PrP}^{\mathrm{C}}$-copper interactions focused on the actual binding event taking place in vitro, monitored the internalization of $\mathrm{PrP}^{\mathrm{C}}$ upon exposure to $\mathrm{Cu}^{2+}$ as a direct indication of in vivo $\mathrm{PrP}^{\mathrm{C}}-\mathrm{Cu}^{2+}$ interaction and/or run assays to show the impact of the 
ablation of $\operatorname{PrP}^{\mathrm{C}}$ expression on steps of the oxidative stress response (Brown et al., 1997d; Haigh and Brown, 2006; Pauly and Harris, 1998). So far only one study has aimed to examine if $\operatorname{PrP}^{\mathrm{C}}$ expression can confer resistance against copper induced toxicity. Haigh and Brown investigated in F14 cell based models the potential of PrP to protect cells against copper toxicity and found that PrP expression effectively protected F14 cells from copper toxicity. (Haigh and Brown, 2006). They also reported that copper when chelated with glycine, generates no ROS and does not trigger oxidative cell response. However, the toxicity due to the "nonoxidative components" of copper toxicity was also inhibited by expression of PrP In case of $\mathrm{Mn}^{2+}$, they found no difference between the toxic effects of the treatments with or without glycine although there is a weaker chelation between $\mathrm{Mn}^{2+}$ and glycine. Nevertheless, at higher concentrations of manganese, $\mathrm{PrP}^{\mathrm{C}}$ expressing $\mathrm{F} 14$ cells showed less vulnerability to $\mathrm{Mn}^{2+}$ toxicity. Interestingly, in the same study, with or without $\mathrm{PrP}^{\mathrm{C}}$ expression, $\mathrm{F} 14$ cell lines exhibited no different viability when incubated with various concentration of $\mathrm{Zn}^{2+}$ (Haigh and Brown, 2006). The studies of Choi and coworkers supported the previous results of Haigh and Brown on manganese, while examining mouse CF10 neural cell lines expressing prion protein $\left(\mathrm{PrP}^{\mathrm{C}}\right.$-cells) and the prion-knockout $\left(\mathrm{PrP}^{\mathrm{KO}}\right.$-cells) cells. $\mathrm{Mn}^{2+}$ treatment induced mitochondrial depolarization and ROS generations were significantly decreased in PrP expressing cells as compared to $\mathrm{PrP}^{\mathrm{KO}}$-cells and $\mathrm{Mn}^{2+}$ treatment caused greater depletion of $\mathrm{GSH}$ in $\mathrm{PrP}^{\mathrm{KO}}$-cells. $\mathrm{Mn}^{2+}$-induced mitochondrial depolarization and ROS production were followed by activation of the apoptotic cell death cascade involving caspase- 9 and 3 in $\mathrm{PrP}^{\mathrm{KO}} \mathrm{CF} 10$ cell line (Choi et al., 2007).. Interestingly, analysis of intracellular $\mathrm{Mn}^{2+}$ levels showed less $\mathrm{Mn}^{2+}$ accumulation in $\mathrm{PrP}^{\mathrm{C}}$-cells as compared to $\operatorname{PrP}^{\mathrm{KO}}$-cells, and they concluded that $\operatorname{PrP}^{\mathrm{C}}$ likely interferes with the uptake of $\mathrm{Mn}^{2+}$ (in addition to its effect on oxidative cell response) (Choi et al., 2007). Regarding $\mathrm{Zn}^{2+}$, Rachidi et al. studied the relationship between PrP and zinc ion intracellular homeostasis using a heterologous epithelial A74 cell line expressing a doxycycline-inducible 
PrP gene, and in contrast to the results of Haigh and Brown (Haigh and Brown, 2006), found that cells would become more resistant to $\mathrm{Zn}^{2+}$ toxicity when PrP-expression was induced (Rachidi et al., 2009).They suggested that $\operatorname{PrP}^{\mathrm{C}}$ mediates intracellular redistribution of the interchangeable $\mathrm{Zn}^{2+}$ rather than interfering with cellular $\mathrm{Zn}^{2+}$ uptake. Furthermore, they put forward an explanation how PrP protects metal induced oxidative stress response: $\operatorname{Pr} \mathrm{P}^{\mathrm{C}}$ expression induces metallothionein (MT) expression, a zinc-upregulated zinc-binding protein, which sequesters metals thereby decreasing their ROS generating capacity.

It is not easy to organize all the existing data into a comprehensible interpretation. The cell lines used in these studies had been derived from different tissues and species. A74 cells are from rabbit kidney while the mouse neuronal cells are from cerebellar (F14) or hippocampal $(\mathrm{Zpl})$ origins. Thus, these results might reflect the various roles PrP plays in defending the cells against toxicity induced by the four transition metals investigated.

It is also clear that metal induced toxicity involves complex and divergent pathways where subtle differences that are not apparently related to the transgene-expression, alter significantly the sensitivity of the cells. For example, Zpl cells become more resistant to $\mathrm{Mn}^{2+}$ treatment by the introduction of the vector control expressing only a GFP protein (Figure 19C and 26). Haigh and Brown found similar effects: vector control cells, expressing only a GFP protein, became significantly more resistant to $\mathrm{Cu}^{2+}$ treatment in $\mathrm{F} 14$ cells, as apparent, if one compares Fig $3 a$ and $b$ in their results (Haigh and Brown, 2006). What they found is a greater difference than the one they observed as a consequence of PrP expression between the viability of the GFP-GPI and GFP-PrP cell lines (Fig 3a and 3b in (Haigh and Brown, 2006)).

Therefore, it is also possible that the effect of PrP expression on these transition metal toxicities is just not robust enough to be distinguishable in all cases. 
Concern might be in our studies about the use of the CAG promoter instead of the natural PrP promoter. The expression levels of PrP in Prnp stable transgenic Zpl-PrP cells and wild type ZW cells are quite modest and comparable. However, the regulation of the PrP promoter is not displayed by this construct. Out of the four metals tested in this study, copper and manganese are reported to increase expression levels of the prion protein but not zinc. Thus, this is not a likely mechanism for providing a general protection against transition metals. In addition to it, Haigh and Brown employed CMV promoter whereas Rachidi et al used a doxycycline inducible TRE promoter, none of them is able to provide a regulation similar to that of the natural PrP promoter, yet, found a protective effect of PrP against copper, manganese and zinc toxicity, respectively. This further supports that the artificial promoter used is not the reason of the lack of PrP's protective effect in our experiments.

Another factor to be taken into consideration while compiling the different data available might be the differences in the methods used. The viability was monitored with MTT assay for F14, CF10 and A74 cells. Cell death for CF10 cells was determined by the Trypan blue exclusion method. Zpl cells were assayed in our study by both approaches, using an alamarBlue viability test and a propidium iodide exclusion method. Even when we compared the same metal $\left(\mathrm{Mn}^{2+}\right)$ for the same cells (Zpl 2-1-PrP and ZW 13-2), interestingly, the relative sensitivities of the cells varied with the two methods used. Zpl 2-1-PrP cells were found more sensitive when assayed for cell viability (alamarBlue) and less sensitive when assayed by dye-exclusion (propidium-iodide) than ZW 13-2 cells (Figure 19C and 26). The two methods appeared not to give fully consistent results; the differing outcomes may partially be due to the fact that the two methods monitor different consequences of the metal treatments. The propidium iodide dye-exclusion method measures the actual percentages of the dead cells at a given time point, while the alamarBlue viability test measures metabolically active cells surviving a one-day treatment relative to that of the untreated cells. 
Also, if one compares the vector cells to the PrP-expressing cells, treatments with three metals (copper, zinc and cobalt) resulted in altering sensitivities when examined with the two methods. The vector cells treated by cobalt are significantly more resistant than the PrPexpressing cells when examined by propidium iodide while there is no significant difference between them when the cell viability assay is performed. By contrast, in case of the manganese treatment they prove to be more resistant than PrP-expressing one when assessed by viability assay, but there is no significant difference between the cell lines when probed by the propidium iodide method. In contrary, against copper the PrP-expressing cells are marginally significantly more resistant compared to the vector control cells when assayed by propidium iodide while no difference is detected in the cell viability assay. Interestingly, only in case of the zinc treatment and only the vector expressing cells show resistance by both techniques, with propidium iodide and with alamarBlue assays, at $100 \mu \mathrm{M}$ concentration at which the propidium iodide experiments were conducted (Figure 25) From these observations, two points may be made: the relative sensitivities of the four cells on Figure 18 and 19 are varied among the four metals, which in turn suggest no identical mechanism of actions nor common way of interference for PrP. These results also show that the methods used might be influential, and these might contribute to the differences seen in respect to the role of PrP in transition metal toxicities of F14, CF10, A74 and Zpl cells (Choi et al., 2007; Haigh and Brown, 2006; Kim et al., 2005; Rachidi et al., 2003b).

We also need to consider that Haigh and Brown used a GFP-PrP fusion protein. We found that the activity of a mutant PrP might be impaired by a fluorescent protein fusion tag; specifically, a $\triangle \mathrm{CR} \operatorname{PrP}$ (Delta105-125) confers drug hypersensitivity to the cells in the absence of WT-PrP (Massignan et al., 2010), whereas, fusion of the fluorescent protein to $\Delta \mathrm{CR}$ PrP abolishes this effect (unpublished result). In contrast to this, the internalization of $\mathrm{N}$ terminally fused GFP-PrP in response to $\mathrm{Cu}^{2+}$ stimuli is similar to the WT protein (Lee et al., 
2001b). Thus, it is likely that PrP-metal interactions are not disturbed by the N-terminal GFP tag, however, it might influence the interactions of PrP with other cell constituents.

Another critical issue is the possibility of a site specific effect of the integration of the transgene and the possible clonal variability. Here we have used only a single gene integration approach, the sleeping beauty (SB) transposase, to generate stabile integrations of the expression cassettes. SB transposon-based transfection is a two-component system consisting of a transposase and a transposon containing inverted repeat (IR) sequences that result in precise integration into a TA dinucleotide. The transposon is designed with an expression cassette of interest flanked by IRs, and SB transposase mediates stable integration and reliable long-term expression of the gene of interest. Its efficiency is higher than that of the random integration by up to two orders of magnitude. In our study, using sleeping beauty resulted cell populations with a few thousands of independent cells with unique integration sites. Thus, considering the size of the human genome, the likeliness that any gene involved in $\operatorname{PrP}$ associated resistance against metal toxicity is invalidated by the transgene integrations is very low. Conceivably, such subpopulation is much smaller than $1 \%$. In addition, Figure 15 shows that close to $100 \%$ of Zpl-PrP cells express PrP, suggesting that only very few positions of the thousands of integrations interfere with the transgene expression ruling out the possibility that a non-expressing sub population muddies the cumulative protective involvement of PrP in the cellular response to divalent cations.

We extended our study to another cell model system, the SH-SY5Y cells where similarly to Zpl cells, we introduced prnp gene or the vector alone by the SB transposase method and generated PrP-expressing and control cells. When performing similar metal toxicity tests like in the case of $\mathrm{Zpl}$ and $\mathrm{ZW}$ cells, the PrP-expressing SH-SY5Y-PrP cells were seen to be more resistant against toxicities of all four metals, as compared to SH-SY5Y- 
vector cells or the SH-SY5Y mother cells, when tested by alamarBlue viability assays. These results seem to support a protective role for PrP against transition metal of $\mathrm{Cu}^{2+}, \mathrm{Mn}^{2+}$, $\mathrm{Zn}^{2+}$ and $\mathrm{Co}^{2+}$ similarly to the observations made in case of $\mathrm{ZW}$ and $\mathrm{Zpl}$ cells and contrary to Zpl-PrP cells. These observations have also revealed that the protective effect in Zpl-vector cells against metal induced toxicity is neither because of the sleeping beauty (SB) transposase based integration nor because of the vector control expressing only GFP protein.

By contrast, unlike in the case of a SB transposase based integration, F14/GFP-GPI, F14/GFP-PrP, CF10/PrP ${ }^{\mathrm{C}}, \mathrm{CF} 10 / \mathrm{PrP}^{\mathrm{KO}}$ and $\mathrm{A} 74$ cell lines were derived from a few unique integration sites. Without examining cell lines originating from different clones it is difficult to rule out a possible effect of the integration sites on the outcome of the experiments. Nevertheless, it is apparent from this short review of the available data that there is no single technical factor that could explain appropriately these seemingly incoherent results. It is likely, that if $\operatorname{PrP}^{\mathrm{C}}$ has any measurable impact on the complex and divergent pathways of metal toxicity, it is not a robust, general effect that is easily discernible in all types of cells. 


\section{Conclusions}

When testing the toxic effects of $\mathrm{Cu}^{2+}, \mathrm{Zn}^{2+}, \mathrm{Mn}^{2+}$ and $\mathrm{Co}^{2+}$ on the mouse hippocampus-derived PrP-expressing ZW and the PrP-KO Zpl cells, we found that:

- PrP expressing wild type ZW 13-2 cells are significantly more resistant to $\mathrm{Cu}^{2+}, \mathrm{Zn}^{2+}$, $\mathrm{Mn}^{2+}$ and $\mathrm{Co}^{2+}$ induced toxicities than PrP- ablated $\mathrm{Zpl} 2-1$ cells, and also they are morphologically less affected by $\mathrm{Cu}^{2+}, \mathrm{Zn}^{2+}, \mathrm{Mn}^{2+}$ and $\mathrm{Co}^{2+}$ induced stresses than PrP- ablated Zpl 2-1 cells.

When introducing PrP-expression into PrP-ablated $\mathrm{Zpl}$ cells in an attempt to draw a more definite link between $\operatorname{PrP}$ expression and cellular resistance against metal toxicities we found that:

- $\quad \operatorname{PrP}$ expressing $\mathrm{Zpl} 2-1-\mathrm{PrP}$ cells are not significantly more resistant to $\mathrm{Cu}^{2+}, \mathrm{Zn}^{2+}$, $\mathrm{Mn}^{2+}$ and $\mathrm{Co}^{2+}$ induced toxicities than its control $\mathrm{Zpl} 2$-1-vector cells, and also, are not less affected morphologically by $\mathrm{Cu}^{2+}, \mathrm{Zn}^{2+}, \mathrm{Mn}^{2+}$ and $\mathrm{Co}^{2+}$ induced stresses than its control Zpl 2-1-vector cells.

- PrP expressing Zpl 2-1-PrP and its control Zpl 2-1-vector cells are more susceptible to $\mathrm{Cu}^{+2}, \mathrm{Zn}^{+2}$ and $\mathrm{Co}^{+2}$ toxicity than $\mathrm{ZW} 13-2$ cells.

- Zpl 2-1-PrP cells are not more resistant to $\mathrm{Cu}^{+2}, \mathrm{Zn}^{+2}$ and $\mathrm{Co}^{+2}$ induced cell death than Zpl 2-1-vector cells.

When testing the effects of $\mathrm{Cu}^{2+}, \mathrm{Zn}^{2+}, \mathrm{Mn}^{2+}$ and $\mathrm{Co}^{2+}$ on another cell model system, the SH-SY5Y human neuroblastoma cells (that have very low PrP expression levels) and SH-SY5Y cells with induced PrP-expression or induced vector-only-expression, we found that:

- PrP expressing SH-SY5Y-PrP cells are significantly more resistant to $\mathrm{Cu}^{2+}$ and $\mathrm{Mn}^{2+}$ induced toxicities than SH-SY5Y and SH-SY5Y-vector cells. 
Although ZW cells established from WT mice are more resistant to all four metal ions tested, we could not establish a clear link between prion protein expression and an increased resistance to metal toxicity, since $\mathrm{PrP}$ expression does not confer increased resistance to $\mathrm{Zpl}$ cells as compared to GFP expression alone. Thus, the increased resistance of ZW cells are either not related to $\mathrm{PrP}^{\mathrm{C}}$ expression, or at least $\mathrm{PrP}^{\mathrm{C}}$ expression is not a sole factor necessary for the increased resistance. In SH-SY5Y cells elevated levels of PrP-expression confer higher resistance to metal toxicities compared to the wild type or the vector-only-expressing cells. Altogether, our results do not seem to support a general protective role for PrP against transition metal toxicity and also, we emphasize the necessity of extreme care when comparing cells derived from PrP knock-out and wild type mice. 


\section{References}

Aguzzi, A., and Calella, A.M. (2009). Prions: protein aggregation and infectious diseases. Physiol. Rev. 89, 1105-1152.

Aguzzi, A., and Lakkaraju, A.K.K. (2015). Cell Biology of Prions and Prionoids: A Status Report. Trends Cell Biol. $x x, 1-12$.

Aguzzi, A., and Polymenidou, M. (2004). Mammalian Prion Biology: One Century of Evolving Concepts. Cell 116, 313-327.

Aguzzi, A., Baumann, F., and Bremer, J. (2008a). The prion's elusive reason for being. Annu. Rev. Neurosci. 31, 439-477.

Aguzzi, A., Sigurdson, C., and Heikenwaelder, M. (2008b). Molecular mechanisms of prion pathogenesis. Annu. Rev. Pathol. 3, 11-40.

Anderson, L., Rossi, D., Linehan, J., Brandner, S., and Weissmann, C. (2004). Transgenedriven expression of the Doppel protein in Purkinje cells causes Purkinje cell degeneration and motor impairment. Proc. Natl. Acad. Sci. U. S. A. 101, 3644-3649.

Arlt, S., Kontush, A., Zerr, I., Buhmann, C., Jacobi, C., Schroter, A., Poser, S., and Beisiegel, U. (2002). Increased lipid peroxidation in cerebrospinal fluid and plasma from patients with Creutzfeldt-Jakob disease. Neurobiol. Dis. 10, 150-156.

Arnold, J.E., Tipler, C., Laszlo, L., Hope, J., Landon, M., and Mayer, R.J. (1995). The abnormal isoform of the prion protein accumulates in late-endosome-like organelles in scrapie-infected mouse brain. J. Pathol. 176, 403-411.

Ayton, S., Lei, P., and Bush, A.I. (2013). Metallostasis in Alzheimer's disease. Free Radic. Biol. Med. 62, 76-89.

Basu, S., Mohan, M.L., Luo, X., Kundu, B., Kong, Q., and Singh, N. (2007). Modulation of proteinase K-resistant prion protein in cells and infectious brain homogenate by redox iron: implications for prion replication and disease pathogenesis. Mol. Biol. Cell 18, 3302-3312.

Berlett, B.S., and Stadtman, E.R. (1997). Protein oxidation in aging, disease, and oxidative stress. J. Biol. Chem. 272, 20313-20316.

Borchelt, D.R., Taraboulos, a., and Prusiner, S.B. (1992). Evidence for synthesis of scrapie prion proteins in the endocytic pathway. J. Biol. Chem. 267, 16188-16199.

Bounhar, Y., Zhang, Y., Goodyer, C.G., and LeBlanc, A. (2001). Prion Protein Protects Human Neurons against Bax-mediated Apoptosis. J. Biol. Chem. 276, 39145-39149.

Brown, D.R., and Besinger, A. (1998). Prion protein expression and superoxide dismutase activity. Biochem. J. 334 ( Pt 2, 423-429.

Brown, L.R., and Harris, D.A. (2003). Copper and zinc cause delivery of the prion protein 
from the plasma membrane to a subset of early endosomes and the Golgi. J. Neurochem. 87, 353-363.

Brown, D.R., Qin, K., Herms, J.W., Madlung, a, Manson, J., Strome, R., Fraser, P.E., Kruck, T., von Bohlen, a, Schulz-Schaeffer, W., et al. (1997a). The cellular prion protein binds copper in vivo. Nature 390, 684-687.

Brown, D.R., Schulz-Schaeffer, W.J., Schmidt, B., and Kretzschmar, H.A. (1997b). Prion protein-deficient cells show altered response to oxidative stress due to decreased SOD-1 activity. Exp. Neurol. 146, 104-112.

Brown, D.R., Brown, D.R., Qin, K., Qin, K., Herms, J.W., Herms, J.W., Madlung, a, Madlung, a, Manson, J., Manson, J., et al. (1997c). The cellular prion protein binds copper in vivo. Nature 390, 684-687.

Brown, D.R., Qin, K., Herms, J.W., Madlung, A., Manson, J., Strome, R., Fraser, P.E., Kruck, T., von Bohlen, A., Schulz-Schaeffer, W., et al. (1997d). The cellular prion protein binds copper in vivo. Nature 390, 684-687.

Brown, D.R., Wong, B.S., Hafiz, F., Clive, C., Haswell, S.J., and Jones, I.M. (1999). Normal prion protein has an activity like that of superoxide dismutase. Biochem. J. 344 Pt 1, 1-5.

Brown, D.R., Hafiz, F., Glasssmith, L.L., Wong, B.S., Jones, I.M., Clive, C., and Haswell, S.J. (2000). Consequences of manganese replacement of copper for prion protein function and proteinase resistance. EMBO J. 19, 1180-1186.

Büeler, H., Fischer, M., Lang, Y., Bluethmann, H., Lipp, H.P., DeArmond, S.J., Prusiner, S.B., Aguet, M., and Weissmann, C. (1992). Normal development and behaviour of mice lacking the neuronal cell-surface PrP protein. Nature 356, 577-582.

Campana, V., Sarnataro, D., and Zurzolo, C. (2005). The highways and byways of prion protein trafficking. Trends Cell Biol. 15, 102-111.

Campana, V., Sarnataro, D., Fasano, C., Casanova, P., Paladino, S., and Zurzolo, C. (2006). Detergent-resistant membrane domains but not the proteasome are involved in the misfolding of a PrP mutant retained in the endoplasmic reticulum. J Cell Sci 119, 433-442.

Cashman, N.R., Loertscher, R., Nalbantoglu, J., Shaw, I., Kascsak, R.J., Bolton, D.C., and Bendheim, P.E. (1990). Cellular isoform of the scrapie agent protein participates in lymphocyte activation. Cell 61, 185-192.

Caughey, B., and Lansbury, P.T. (2003). Protofibrils, pores, fibrils, and neurodegeneration: separating the responsible protein aggregates from the innocent bystanders. Annu. Rev. Neurosci. 26, 267-298.

Caughey, B., and Raymond, G.J. (1991). The scrapie-associated form of PrP is made from a cell surface precursor that is both protease- and phospholipase-sensitive. J. Biol. Chem. 266, $18217-18223$.

Choi, C.J., Anantharam, V., Saetveit, N.J., Houk, R.S., Kanthasamy, A., and Kanthasamy, 
A.G. (2007). Normal cellular prion protein protects against manganese-induced oxidative stress and apoptotic cell death. Toxicol. Sci. 98, 495-509.

Ciric, D., and Rezaei, H. (2015). Biochemical insight into the prion protein family. Front. Cell Dev. Biol. 3, 1-8.

Collinge, J. (2001). Prion diseases of humans and animals: their causes and molecular basis. Annu. Rev. Neurosci. 24, 519-550.

Cui, T., Holme, A., Sassoon, J., and Brown, D.R. (2003). Analysis of doppel protein toxicity. Mol. Cell. Neurosci. 23, 144-155.

Dodelet, V.C., and Cashman, N.R. (1998). Prion protein expression in human leukocyte differentiation. Blood 91, 1556-1561.

Drisaldi, B., Stewart, R.S., Adles, C., Stewart, L.R., Quaglio, E., Biasini, E., Fioriti, L., Chiesa, R., and Harris, D.A. (2003). Mutant PrP is delayed in its exit from the endoplasmic reticulum, but neither wild-type nor mutant $\operatorname{PrP}$ undergoes retrotranslocation prior to proteasomal degradation. J Biol Chem 278, 21732-21743.

Eghiaian, F., Grosclaude, J., Lesceu, S., Debey, P., Doublet, B., Tréguer, E., Rezaei, H., and Knossow, M. (2004). Insight into the PrPC-->PrPSc conversion from the structures of antibody-bound ovine prion scrapie-susceptibility variants. Proc. Natl. Acad. Sci. U. S. A. $101,10254-10259$.

Fernaeus, S., Hälldin, J., Bedecs, K., and Land, T. (2005). Changed iron regulation in scrapieinfected neuroblastoma cells. Mol. Brain Res. 133, 266-273.

Fevrier, B., Vilette, D., Archer, F., Loew, D., Faigle, W., Vidal, M., Laude, H., and Raposo, G. (2004). Cells release prions in association with exosomes. Proc. Natl. Acad. Sci. U. S. A. 101, 9683-9688.

Flechsig, E., Hegyi, I., Leimeroth, R., Zuniga, A., Rossi, D., Cozzio, A., Schwarz, P., Rülicke, T., Götz, J., Aguzzi, A., et al. (2003). Expression of truncated PrP targeted to Purkinje cells of PrP knockout mice causes Purkinje cell death and ataxia. EMBO J. 22, 3095-3101.

Grabundzija, I., Irgang, M., Mátés, L., Belay, E., Matrai, J., Gogol-Döring, A., Kawakami, K., Chen, W., Ruiz, P., Chuah, M.K.L., et al. (2010). Comparative analysis of transposable element vector systems in human cells. Mol. Ther. 18, 1200-1209.

Graner, E., Mercadante, A.F., Zanata, S.M., Forlenza, O. V., Cabral, A.L.B., Veiga, S.S., Juliano, M.A., Roesler, R., Walz, R., Minetti, A., et al. (2000). Cellular prion protein binds laminin and mediates neuritogenesis. Mol. Brain Res. 76, 85-92.

Guentchev, M., Voigtländer, T., Haberler, C., Groschup, M.H., and Budka, H. (2000). Evidence for oxidative stress in experimental prion disease. Neurobiol. Dis. 7, 270-273.

Guentchev, M., Siedlak, S.L., Jarius, C., Tagliavini, F., Castellani, R.J., Perry, G., Smith, M.A., and Budka, H. (2002). Oxidative damage to nucleic acids in human prion disease. Neurobiol Dis 9, 275-281. 
Haigh, C.L., and Brown, D.R. (2006). Prion protein reduces both oxidative and non-oxidative copper toxicity. J. Neurochem. 98, 677-689.

Haire, L.F., Whyte, S.M., Vasisht, N., Gill, A.C., Verma, C., Dodson, E.J., Dodson, G.G., and Bayley, P.M. (2004). The crystal structure of the globular domain of sheep prion protein. J Mol Biol 336, 1175-1183.

Haraguchi, T., Fisher, S., Olofsson, S., Endo, T., Groth, D., Tarentino, A., Borchelt, D.R., Teplow, D., Hood, L., Burlingame, A., et al. (1989). Asparagine-linked glycosylation of the scrapie and cellular prion proteins. Arch. Biochem. Biophys. 274, 1-13.

Holada, K., Simak, J., Risitano, A.M., Maciejewski, J., Young, N.S., and Vostal, J.G. (2002). Activated platelets of patients with paroxysmal nocturnal hemoglobinuria express cellular prion protein. Blood 100, 341-343.

Hosszu, L.L., Baxter, N.J., Jackson, G.S., Power, A., Clarke, A.R., Waltho, J.P., Craven, C.J., and Collinge, J. (1999). Structural mobility of the human prion protein probed by backbone hydrogen exchange. Nat. Struct. Biol. 6, 740-743.

Hutter, G., Heppner, F.L., and Aguzzi, A. (2003). No superoxide dismutase activity of cellular prion protein in vivo. Biol. Chem. 384, 1279-1285.

Jackson, G.S., Hosszu, L.L.P., Collinge, J., Waltho, J.P., Gibbs, N., Clarke, A.R., and Murray, I. (2001a). Location and properties of metal-binding sites on the human prion protein. Proc. Natl. Acad. Sci. U. S. A. 98, 8531-8535.

Jackson, G.S., Murray, I., Hosszu, L.L., Gibbs, N., Waltho, J.P., Clarke, A.R., and Collinge, J. (2001b). Location and properties of metal-binding sites on the human prion protein. Proc. Natl. Acad. Sci. U. S. A. 98, 8531-8535.

Jarrett, J.T., and Lansbury, P.T. (1993). Seeding "one-dimensional crystallization" of amyloid: A pathogenic mechanism in Alzheimer's disease and scrapie? Cell 73, 1055-1058.

Jeffrey, M., Goodsir, C.M., Bruce, M.E., McBride, P.A., Scott, J.R., and Halliday, W.G. (1992). Infection specific prion protein (PrP) accumulates on neuronal plasmalemma in scrapie infected mice. Neurosci Lett 147, 106-109.

Jellinger, K. a. (2012). Neuropathology of sporadic Parkinson's disease: Evaluation and changes of concepts. Mov. Disord. 27, 8-30.

Jones, S., Batchelor, M., Bhelt, D., Clarke, A.R., Collinge, J., and Jackson, G.S. (2005). Recombinant prion protein does not possess SOD-1 activity. Biochem. J. 392, 309-312.

Kaneko, K., Vey, M., Scott, M., Pilkuhn, S., Cohen, F.E., and Prusiner, S.B. (1997). COOHterminal sequence of the cellular prion protein directs subcellular trafficking and controls conversion into the scrapie isoform. Proc. Natl. Acad. Sci. U. S. A. 94, 2333-2338.

Kanu, N., Imokawa, Y., Drechsel, D.N., Williamson, R.A., Birkett, C.R., Bostock, C.J., and Brockes, J.P. (2002). Transfer of scrapie prion infectivity by cell contact in culture. Curr. Biol. 12, 523-530. 
Kawahara, M., Koyama, H., Nagata, T., and Sadakane, Y. (2011). Zinc, copper, and carnosine attenuate neurotoxicity of prion fragment PrP106-126. Metallomics 3, 726-734.

Khosravani, H., Zhang, Y., Tsutsui, S., Hameed, S., Altier, C., Hamid, J., Chen, L., Villemaire, M., Ali, Z., Jirik, F.R., et al. (2008). Prion protein attenuates excitotoxicity by inhibiting NMDA receptors. J. Cell Biol. 181, 551-555.

Kim, B.H., Lee, H.G., Choi, J.K., Kim, J. Il, Choi, E.K., Carp, R.I., and Kim, Y.S. (2004). The cellular prion protein (PrPC) prevents apoptotic neuronal cell death and mitochondrial dysfunction induced by serum deprivation. Mol. Brain Res. 124, 40-50.

Kim, B.-H., Kim, J.-I., Choi, E.-K., Carp, R.I., and Kim, Y.-S. (2005). A neuronal cell line that does not express either prion or doppel proteins. Neuroreport 16, 425-429.

Kim, N.H., Park, S.J., Jin, J.K., Kwon, M.S., Choi, E.K., Carp, R.I., and Kim, Y.S. (2000). Increased ferric iron content and iron-induced oxidative stress in the brains of scrapie-infected mice. Brain Res. 884, 98-103.

Klamt, F., Dal-Pizzol, F., Conte da Frota, M.L., Walz, R., Andrades, M.E., da Silva, E.G., Brentani, R.R., Izquierdo, I., and Fonseca Moreira, J.C. (2001). Imbalance of antioxidant defense in mice lacking cellular prion protein. Free Radic. Biol. Med. 30, 1137-1144.

Knaus, K., Morillas, M., Swietnicki, W., Malone, M., Surewicz, W., and Yee, V. (2001). Crystal structure of the human prion protein reveals a mechanism for oligomerization. Nat. Struct. Biol. 8, 770-774.

Kolacsek, O., Erdei, Z., and Apati, A. (2014). Excision efficiency is not strongly coupled to transgenic rate: cell type dependent transposition efficiency of Sleeping Beauty and piggyBac DNA transposons. ... Gene Ther. Part ... 1-38.

Kozlowski, H., Potocki, S., Remelli, M., Rowinska-Zyrek, M., and Valensin, D. (2013). Specific metal ion binding sites in unstructured regions of proteins. Coord. Chem. Rev. 257, 2625-2638.

Kristiansen, M., Messenger, M.J., Klöhn, P.C., Brandner, S., Wadsworth, J.D.F., Collinge, J., and Tabrizi, S.J. (2005). Disease-related prion protein forms aggresomes in neuronal cells leading to caspase activation and apoptosis. J. Biol. Chem. 280, 38851-38861.

Kuwahara, C., Takeuchi, A.M., Nishimura, T., Haraguchi, K., Kubosaki, A., Matsumoto, Y., Saeki, K., Matsumoto, Y., Yokoyama, T., Itohara, S., et al. (1999). Prions prevent neuronal cell-line death. Nature 400, 225-226.

Labbadia, J., and Morimoto, R.I. (2013). Huntington's disease: Underlying molecular mechanisms and emerging concepts. Trends Biochem. Sci. 38, 378-385.

LaFerla, F.M., Green, K.N., and Oddo, S. (2007). Intracellular amyloid-beta in Alzheimer's disease. Nat. Rev. Neurosci. 8, 499-509.

Lampo, E., Van Poucke, M., Hugot, K., Hayes, H., Van Zeveren, A., and Peelman, L.J. (2007). Characterization of the genomic region containing the Shadow of Prion Protein 
(SPRN) gene in sheep. BMC Genomics 8, 138.

Lampo, E., Van Poucke, M., Vandesompele, J., Erkens, T., Van Zeveren, A., and Peelman, L.J. (2009). Positive correlation between relative mRNA expression of PRNP and SPRN in cerebral and cerebellar cortex of sheep. Mol. Cell. Probes 23, 60-64.

Lee, H.G., Park, S.J., Choi, E.K., Carp, R.I., and Kim, Y.S. (1999). Increased expression of prion protein is associated with changes in dopamine metabolism and MAO activity in PC12 cells. J. Mol. Neurosci. 13, 121-126.

Lee, J.C., Son, Y.O., Pratheeshkumar, P., and Shi, X. (2012). Oxidative stress and metal carcinogenesis. Free Radic. Biol. Med. 53, 742-757.

Lee, K.S., Magalhães, A.C., Zanata, S.M., Brentani, R.R., Martins, V.R., and Prado, M. a M. (2001a). Internalization of mammalian fluorescent cellular prion protein and N-terminal deletion mutants in living cells. J. Neurochem. 79, 79-87.

Lee, K.S., Magalhães, A.C., Zanata, S.M., Brentani, R.R., Martins, V.R., and Prado, M.A.M. (2001b). Internalization of mammalian fluorescent cellular prion protein and N-terminal deletion mutants in living cells. J. Neurochem. 79, 79-87.

Li, A., Dong, J., and Harris, D.A. (2004). Cell surface expression of the prion protein in yeast does not alter copper utilization phenotypes. J. Biol. Chem. 279, 29469-29477.

Linden, R., Martins, V.R., Prado, M. a M., Cammarota, M., Izquierdo, I., and Brentani, R.R. (2008). Physiology of the prion protein. Physiol. Rev. 88, 673-728.

Liu, M.L., Li, Y.X., Zhou, X.M., and Zhao, D.M. (2008). Copper(II) inhibits in vitro conformational conversion of ovine prion protein triggered by low $\mathrm{pH}$. J. Biochem. 143, 333337.

Loubet, D., Dakowski, C., Pietri, M., Pradines, E., Bernard, S., Callebert, J., Ardila-Osorio, H., Mouillet-Richard, S., Launay, J.-M., Kellermann, O., et al. (2012). Neuritogenesis: the prion protein controls $\beta 1$ integrin signaling activity. FASEB J. 26, 678-690.

Ma, J., and Lindquist, S. (2002). Conversion of PrP to a self-perpetuating PrPSc-like conformation in the cytosol. Science 298, 1785-1788.

Magalhães, A.C., Silva, J. a, Lee, K.S., Martins, V.R., Prado, V.F., Ferguson, S.S.G., Gomez, M. V, Brentani, R.R., and Prado, M. a M. (2002). Endocytic intermediates involved with the intracellular trafficking of a fluorescent cellular prion protein. J Biol Chem 277, 3331133318.

Makrinou, E., Collinge, J., and Antoniou, M. (2002). Genomic characterization of the human prion protein (PrP) gene locus. Mamm. Genome 13, 696-703.

Mangé, A., Milhavet, O., Umlauf, D., Harris, D., and Lehmann, S. (2002). PrP-dependent cell adhesion in N2a neuroblastoma cells. FEBS Lett. 514, 159-162.

Mangé, A., Crozet, C., Lehmann, S., and Béranger, F. (2004). Scrapie-like prion protein is 
translocated to the nuclei of infected cells independently of proteasome inhibition and interacts with chromatin. J. Cell Sci. 117, 2411-2416.

Massignan, T., Stewart, R.S., Biasini, E., Solomon, I.H., Bonetto, V., Chiesa, R., and Harris, D. a. (2010). A novel, drug-based, cellular assay for the activity of neurotoxic mutants of the prion protein. J. Biol. Chem. 285, 7752-7765.

McKenzie, D., Bartz, J., Mirwald, J., Olander, D., Marsh, R., and Aiken, J. (1998). Reversibility of scrapie inactivation is enhanced by copper. J. Biol. Chem. 273, 25545-25547.

McKintosh, E., Tabrizi, S.J., and Collinge, J. (2003). Prion diseases. J. Neurovirol. 9, 183193.

McLennan, N.F., Brennan, P.M., McNeill, A., Davies, I., Fotheringham, A., Rennison, K.A., Ritchie, D., Brannan, F., Head, M.W., Ironside, J.W., et al. (2004). Prion protein accumulation and neuroprotection in hypoxic brain damage.

La Mendola, D., and Rizzarelli, E. (2014). Evolutionary implications of metal binding features in different species' prion protein: an inorganic point of view. Biomolecules 4, 546565.

Meyer, R.K., McKinley, M.P., Bowman, K.A., Braunfeld, M.B., Barry, R.A., and Prusiner, S.B. (1986). Separation and properties of cellular and scrapie prion proteins. Proc. Natl. Acad. Sci. U. S. A. 83, 2310-2314.

Miesbauer, M., Bamme, T., Riemer, C., Oidtmann, B., Winklhofer, K.F., Baier, M., and Tatzelt, J. (2006). Prion protein-related proteins from zebrafish are complex glycosylated and contain a glycosylphosphatidylinositol anchor. Biochem. Biophys. Res. Commun. 341, 218 224.

Milhavet, O., McMahon, H.E., Rachidi, W., Nishida, N., Katamine, S., Mangé, A., Arlotto, M., Casanova, D., Riondel, J., Favier, A., et al. (2000). Prion infection impairs the cellular response to oxidative stress. Proc. Natl. Acad. Sci. U. S. A. 97, 13937-13942.

Mironov, A., Latawiec, D., Wille, H., Bouzamondo-Bernstein, E., Legname, G., Williamson, R.A., Burton, D., DeArmond, S.J., Prusiner, S.B., and Peters, P.J. (2003). Cytosolic prion protein in neurons. J. Neurosci. 23, 7183-7193.

Miura, T., Sasaki, S., Toyama, A., and Takeuchi, H. (2005). Copper reduction by the octapeptide repeat region of prion protein: $\mathrm{pH}$ dependence and implications in cellular copper uptake. Biochemistry 44, 8712-8720.

Mo, H., Moore, R.C., Cohen, F.E., Westaway, D., Prusiner, S.B., Wright, P.E., and Dyson, H.J. (2001). Two different neurodegenerative diseases caused by proteins with similar structures. Proc. Natl. Acad. Sci. U. S. A. 98, 2352-2357.

Molnár, E., Kuntam, S., Cingaram, P.K.R., Peksel, B., Suresh, B., Fábián, G., Fehér, L.Z., Bokros, A., Medgyesi, Á., Ayaydin, F., et al. (2013). Combination of small molecule microarray and confocal microscopy techniques for live cell staining fluorescent dye 
discovery. Molecules 18, 9999-10013.

Moore, R.C., Lee, I.Y., Silverman, G.L., Harrison, P.M., Strome, R., Heinrich, C., Karunaratne, A., Pasternak, S.H., Chishti, M.A., Liang, Y., et al. (1999). Ataxia in prion protein $(\mathrm{PrP})$-deficient mice is associated with upregulation of the novel PrP-like protein doppel. J. Mol. Biol. 292, 797-817.

Morris, R.J., Parkyn, C.J., and Jen, A. (2006). Traffic of prion protein between different compartments on the neuronal surface, and the propagation of prion disease. FEBS Lett. 580, $5565-5571$.

Mouillet-Richard, S., Ermonval, M., Chebassier, C., Laplanche, J.L., Lehmann, S., Launay, J.M., and Kellermann, O. (2000). Signal transduction through prion protein. Science 289, $1925-1928$.

Di Natale, G., Osz, K., Kállay, C., Pappalardo, G., Sanna, D., Impellizzeri, G., Sóvágó, I., and Rizzarelli, E. (2013). Affinity, speciation, and molecular features of copper(II) complexes with a prion tetraoctarepeat domain in aqueous solution: Insights into old and new results. Chem. - A Eur. J. 19, 3751-3761.

Nishida, N., Tremblay, P., Sugimoto, T., Shigematsu, K., Shirabe, S., Petromilli, C., Erpel, S.P., Nakaoke, R., Atarashi, R., Houtani, T., et al. (1999). A mouse prion protein transgene rescues mice deficient for the prion protein gene from purkinje cell degeneration and demyelination. Lab. Invest. 79, 689-697.

Oh, J.M., Shin, H.Y., Park, S.J., Kim, B.H., Choi, J.K., Choi, E.K., Carp, R.I., and Kim, Y.S. (2008). The involvement of cellular prion protein in the autophagy pathway in neuronal cells. Mol. Cell. Neurosci. 39, 238-247.

Oh, J.M., Choi, E.K., Carp, R.I., and Kim, Y.S. (2012). Oxidative stress impairs autophagic flux in prion protein-deficient hippocampal cells. Autophagy 8, 1448-1461.

Pan, K.M., Stahl, N., and Prusiner, S.B. (1992). Purification and properties of the cellular prion protein from Syrian hamster brain. Protein Sci 1, 1343-1352.

Pan, T., Wong, B.S., Liu, T., Li, R., Petersen, R.B., and Sy, M.S. (2002). Cell-surface prion protein interacts with glycosaminoglycans. Biochem J 368, 81-90.

Pandey, K.K., Snyder, J.P., Liotta, D.C., and Musaev, D.G. (2010). Computational Studies of Transition Metal Selectivity of Octapeptide Repeat Region of Prion Protein (PrP). J. Phys. Chem. B 114, 1127-1135.

Parkin, E.T., Watt, N.T., Turner, A.J., and Hooper, N.M. (2004). Dual Mechanisms for Shedding of the Cellular Prion Protein. J. Biol. Chem. 279, 11170-11178.

Parkyn, C.J., Vermeulen, E.G.M., Mootoosamy, R.C., Sunyach, C., Jacobsen, C., Oxvig, C., Moestrup, S., Liu, Q., Bu, G., Jen, A., et al. (2008). LRP1 controls biosynthetic and endocytic trafficking of neuronal prion protein. J. Cell Sci. 121, 773-783.

Pauly, P.C., and Harris, D.A. (1998). Copper stimulates endocytosis of the prion protein. J. 
Biol. Chem. 273, 33107-33110.

Perera, W.S., and Hooper, N.M. (2001). Ablation of the metal ion-induced endocytosis of the prion protein by disease-associated mutation of the octarepeat region. Curr. Biol. 11, 519523.

Premzl, M., Sangiorgio, L., Strumbo, B., Marshall Graves, J.A., Simonic, T., and Gready, J.E. (2003). Shadoo, a new protein highly conserved from fish to mammals and with similarity to prion protein. Gene 314, 89-102.

Prusiner, S.B. (1991). Molecular biology of prion diseases. Science 252, 1515-1522.

Prusiner, S.B. (1996). Molecular biology and pathogenesis of prion diseases. Trends Biochem. Sci. 21, 482-487.

Prusiner, S.B. (1998a). Prions. Proc. Natl. Acad. Sci. U. S. A. 95, 13363-13383.

Prusiner, S.B. (1998b). The prion diseases. Brain Pathol. 8, 499-513.

Qin, K., Yang, D.S., Yang, Y., Chishti, M.A., Meng, L.J., Kretzschmar, H.A., Yip, C.M., Fraser, P.E., and Westaway, D. (2000). Copper(II)-induced conformational changes and protease resistance in recombinant and cellular PrP: Effect of protein age and deamidation. J. Biol. Chem. 275, 19121-19131.

Quaglio, E., Chiesa, R., and Harris, D.A. (2001). Copper Converts the Cellular Prion Protein into a Protease-resistant Species That is Distinct from the Scrapie Isoform. J. Biol. Chem. $276,11432-11438$.

Rachidi, W., Mangé, A., Senator, A., Guiraud, P., Riondel, J., Benboubetra, M., Favier, A., and Lehmann, S. (2003a). Prion infection impairs copper binding of cultured cells. J. Biol. Chem. 278, 14595-14598.

Rachidi, W., Vilette, D., Guiraud, P., Arlotto, M., Riondel, J., Laude, H., Lehmann, S., and Favier, A. (2003b). Expression of prion protein increases cellular copper binding and antioxidant enzyme activities but not copper delivery. J. Biol. Chem. 278, 9064-9072.

Rachidi, W., Chimienti, F., Aouffen, M., Senator, A., Guiraud, P., Seve, M., and Favier, A. (2009). Prion protein protects against zinc-mediated cytotoxicity by modifying intracellular exchangeable zinc and inducing metallothionein expression. J. Trace Elem. Med. Biol. 23, 214-223.

Rampersad, S.N. (2012). Multiple applications of alamar blue as an indicator of metabolic function and cellular health in cell viability bioassays. Sensors (Switzerland) 12, 1234712360.

Rana, A., Gnaneswari, D., Bansal, S., and Kundu, B. (2009). Prion metal interaction: Is prion pathogenesis a cause or a consequence of metal imbalance? Chem. Biol. Interact. 181, 282291.

Riek, R., Hornemann, S., Wider, G., Billeter, M., Glockshuber, R., and Wüthrich, K. (1996). 
NMR structure of the mouse prion protein domain $\operatorname{PrP}(121-231)$. Nature $382,180-182$.

Riek, R., Wider, G., Billeter, M., Hornemann, S., Glockshuber, R., and Wüthrich, K. (1998). Prion protein NMR structure and familial human spongiform encephalopathies. Proc. Natl. Acad. Sci. U. S. A. 95, 11667-11672.

Rossi, D., Cozzio, A., Flechsig, E., Klein, M.A., Rülicke, T., Aguzzi, A., and Weissmann, C. (2001). Onset of ataxia and Purkinje cell loss in PrP null mice inversely correlated with Dpl level in brain. EMBO J. 20, 694-702.

Russo, N., Marino, T., and Toscano, M. (2011). Interaction of the $\mathrm{Mn}(2+), \mathrm{Co}(2+), \mathrm{Ni}(2+)$, and $\mathrm{Zn}(2+)$ with Prion Protein HGGGW Pentapeptide Model. Int. J. Quantum Chem. 111, $1152-1162$.

Sakaguchi, S., Katamine, S., Nishida, N., Moriuchi, R., Shigematsu, K., Sugimoto, T., Nakatani, A., Kataoka, Y., Houtani, T., Shirabe, S., et al. (1996). Loss of cerebellar Purkinje cells in aged mice homozygous for a disrupted PrP gene. Nature 380, 528-531.

Sakudo, A., Hamaishi, M., Hosokawa-Kanai, T., Tuchiya, K., Nishimura, T., Saeki, K., Matsumoto, Y., Ueda, S., and Onodera, T. (2003). Absence of superoxide dismutase activity in a soluble cellular isoform of prion protein produced by baculovirus expression system. Biochem. Biophys. Res. Commun. 307, 678-683.

Sarnataro, D., Paladino, S., Campana, V., Grassi, J., Nitsch, L., and Zurzolo, C. (2002). PrPC is sorted to the basolateral membrane of epithelial cells independently of its association with rafts. Traffic 3, 810-821.

Sarnataro, D., Campana, V., Paladino, S., Stornaiuolo, M., Nitsch, L., and Zurzolo, C. (2004). $\operatorname{PrP}(C)$ association with lipid rafts in the early secretory pathway stabilizes its cellular conformation. Mol. Biol. Cell 15, 4031-4042.

Selkoe, D.J. (1991). The Molecular Pathology of Alzheimer's Disease. Neuron 6, 487-498.

Shmerling, D., Hegyi, I., Fischer, M., Blättler, T., Brandner, S., Götz, J., Rülicke, T., Flechsig, E., Cozzio, A., Von Mering, C., et al. (1998). Expression of amino-terminally truncated PrP in the mouse leading to ataxia and specific cerebellar lesions. Cell 93, 203-214.

Shyng, S.L., Huber, M.T., and Harris, D. a. (1993). A prion protein cycles between the cell surface and an endocytic compartment in cultured neuroblastoma cells. J. Biol. Chem. 268, $15922-15928$.

Shyng, S.L., Heuser, J.E., and Harris, D. a. (1994). A glycolipid-anchored prion protein is endocytosed via clathrin-coated pits. J. Cell Biol. 125, 1239-1250.

Silverman, G.L., Qin, K., Moore, R.C., Yang, Y., Mastrangelo, P., Tremblay, P., Prusiner, S.B., Cohen, F.E., and Westaway, D. (2000). Doppel is an N-glycosylated, glycosylphosphatidylinositol-anchored protein: Expression in testis and ectopic production in the brains of Prnp(0/0) mice predisposed to purkinje cell loss. J. Biol. Chem. 275, 2683426841. 
Singh, N., Das, D., Singh, A., and Mohan, M.L. (2010). Prion protein and metal interaction: Physiological and pathological implications. Curr. Issues Mol. Biol. 12, 99-108.

Solomon, I.H., Biasini, E., and Harris, D.A. (2012). Ion channels induced by the prion protein: Mediators of neurotoxicity. Prion 6, 40-45.

Stahl, N., Borchelt, D.R., Hsiao, K., and Prusiner, S.B. (1987). Scrapie prion protein contains a phosphatidylinositol glycolipid. Cell 51, 229-240.

Stöckel, J., Safar, J., Wallace, A.C., Cohen, F.E., and Prusiner, S.B. (1998). Prion protein selectively binds copper(II) ions. Biochemistry 37, 7185-7193.

Sunyach, C. (2003). The mechanism of internalization of glycosylphosphatidylinositolanchored prion protein. EMBO J. 22, 3591-3601.

Taraboulos, A., Raeber, A.J., Borchelt, D.R., Serban, D., and Prusiner, S.B. (1992). Synthesis and trafficking of prion proteins in cultured cells. Mol. Biol. Cell 3, 851-863.

Taylor, D.R., and Hooper, N.M. (2007). The low-density lipoprotein receptor-related protein 1 (LRP1) mediates the endocytosis of the cellular prion protein. Biochem. J. 402, 17-23.

Taylor, D.R., Watt, N.T., Perera, W.S.S., and Hooper, N.M. (2005). Assigning functions to distinct regions of the $\mathrm{N}$-terminus of the prion protein that are involved in its copperstimulated, clathrin-dependent endocytosis. J. Cell Sci. 118, 5141-5153.

Thackray, A.M., Knight, R., Haswell, S.J., Bujdoso, R., and Brown, D.R. (2002). Metal imbalance and compromised antioxidant function are early changes in prion disease. Biochem. J. 362, 253-258.

Vassallo, N., and Herms, J.W. (2003). Cellular prion protein function in copper homeostasis and redox signalling at the synapse. J. Neurochem. 86, 538-544.

Vey, M., Pilkuhn, S., Wille, H., Nixon, R., DeArmond, S.J., Smart, E.J., Anderson, R.G., Taraboulos, A., and Prusiner, S.B. (1996). Subcellular colocalization of the cellular and scrapie prion proteins in caveolae-like membranous domains. Proc. Natl. Acad. Sci. U. S. A. 93, 14945-14949.

Viles, J.H., Cohen, F.E., Prusiner, S.B., Goodin, D.B., Wright, P.E., and Dyson, H.J. (1999). Copper binding to the prion protein: structural implications of four identical cooperative binding sites. Proc. Natl. Acad. Sci. U. S. A. 96, 2042-2047.

Waggoner, D.J., Drisaldi, B., Bartnikas, T.B., Casareno, R.L.B., Prohaska, J.R., Gitlin, J.D., and Harris, D.A. (2000). Brain copper content and cuproenzyme activity do not vary with prion protein expression level. J. Biol. Chem. 275, 7455-7458.

Warner, R.G., Hundt, C., Weiss, S., and Turnbull, J.E. (2002). Identification of the heparan sulfate binding sites in the cellular prion protein. J. Biol. Chem. 277, 18421-18430.

Watt, N.T., and Hooper, N.M. (2003). The prion protein and neuronal zinc homeostasis. Trends Biochem. Sci. 28, 406-410. 
Watt, N.T., Taylor, D.R., Kerrigan, T.L., Griffiths, H.H., Rushworth, J. V., Whitehouse, I.J., and Hooper, N.M. (2012). Prion protein facilitates uptake of zinc into neuronal cells. Nat. Commun. 3, 1134.

Watts, J.C., and Westaway, D. (2007). The prion protein family: Diversity, rivalry, and dysfunction. Biochim. Biophys. Acta - Mol. Basis Dis. 1772, 654-672.

Watts, J.C., Drisaldi, B., Ng, V., Yang, J., Strome, B., Horne, P., Sy, M.-S., Yoong, L., Young, R., Mastrangelo, P., et al. (2007). The CNS glycoprotein Shadoo has PrP(C)-like protective properties and displays reduced levels in prion infections. EMBO J. 26, 40384050.

Watts, J.C., Stöhr, J., Bhardwaj, S., Wille, H., Oehler, A., DeArmond, S.J., Giles, K., and Prusiner, S.B. (2011). Protease-resistant prions selectively decrease Shadoo protein. PLoS Pathog. 7.

Westaway, D., Genovesi, S., Daude, N., Brown, R., Lau, A., Lee, I., Mays, C.E., Coomaraswamy, J., Canine, B., Pitstick, R., et al. (2011). Down-regulation of shadoo in prion infections traces a pre-clinical event inversely related to PrP sc accumulation. PLoS Pathog. 7.

Westergard, L., Christensen, H.M., and Harris, D.A. (2007). The cellular prion protein $(\operatorname{PrP}(\mathrm{C}))$ : its physiological function and role in disease. Biochim. Biophys. Acta 1772, 629644.

White, A.R., Collins, S.J., Maher, F., Jobling, M.F., Stewart, L.R., Thyer, J.M., Beyreuther, K., Masters, C.L., and Cappai, R. (1999). Prion protein-deficient neurons reveal lower glutathione reductase activity and increased susceptibility to hydrogen peroxide toxicity. Am. J. Pathol. 155, 1723-1730.

Wong, B.S., Chen, S.G., Colucci, M., Xie, Z., Pan, T., Liu, T., Li, R., Gambetti, P., Sy, M.S., and Brown, D.R. (2001a). Aberrant metal binding by prion protein in human prion disease. J. Neurochem. 78, 1400-1408.

Wong, B.S., Liu, T., Li, R., Pan, T., Petersen, R.B., Smith, M.A., Gambetti, P., Perry, G., Manson, J.C., Brown, D.R., et al. (2001b). Increased levels of oxidative stress markers detected in the brains of mice devoid of prion protein. J. Neurochem. 76, 565-572.

Wong, B.S., Brown, D.R., Pan, T., Whiteman, M., Liu, T., Bu, X., Li, R., Gambetti, P., Olesik, J., Rubenstein, R., et al. (2001c). Oxidative impairment in scrapie-infected mice is associated with brain metals perturbations and altered antioxidant activities. J. Neurochem. 79, 689-698.

Yamaguchi, N., Sakaguchi, S., Shigematsu, K., Okimura, N., and Katamine, S. (2004). Doppel-induced Purkinje cell death is stoichiometrically abrogated by prion protein. Biochem. Biophys. Res. Commun. 319, 1247-1252. 


\section{Acknowledgement}

This doctoral thesis is a significant part of the research study that I did as a Ph.D. student in the group of Dr. Ervin Welker. Right from the beginning until the completion of the study, I had the good opportunity to work with many people whose contribution in different ways to the study have helped in making my Ph.D. thesis very special. I would like to sincerely thank all these people who have made a noteworthy impact on my life.

Firstly, I would like to convey my immense gratefulness to my supervisor Dr. Ervin Welker, for giving me an interesting and important research topic, for his critical supervision, guidance and also for all his personal care.

I am deeply indebted to my co-supervisor Dr. Elfrieda Fodor, for her valuable support and major discussions and suggestions during the entire Ph.D. timeline.

I would like to thank Anatal Nyeste for constructing plasmids and generating stable cell lines.

I would like to thank Divya Teja Dondapati for her valuable help while doing flow cytometry analysis.

I would like to thank all other members of the Conformational Diseases group for their kind support and co-operation, much needed for me to able to work in the lab, especially to Andrea Papdine Morovicz for her technical assistance.

I would like to thank Sudheer Babu Sangeetham for his help and support throughout my Ph.D. studies.

I wanted to extend my thanks to Dr. Ferhan Ayaydin for his help in the microscopy studies and his valuable suggestions during the entire Ph.D. timeline.

I would like to thank Edit Kotogány and the Flow Cytometry Laboratory, for the flow cytometry analysis. 
I thank the group of Dr. Laszlo Vigh for providing possibility and help using their fluorescence plate reader instrument.

My special thanks to Soujanya Kuntam for her special care and support throughout my Ph.D. studies.

I would also like to thank my friend Dr. Jayapal Reddy Mallareddy, for his inconspicuous support throughout my higher education.

I am also very thankful to the ITC community, in particularly to the little Indian community in Szeged for their support and to Szeged salsa community for making even more memorable time. I also take this opportunity to express my gratitude to all the administrative staff at the Institute of Biochemistry, and the Biological Research Centre.

Finally, I am very grateful to my parents Kalavatamma and Pentareddy for their support and endless love, which has been the greatest encouragement for my success. I wish to say a special thanks to my brothers Rajashekhar Reddy and Purushotham Reddy for their invaluable support in each step of my life. 


\section{Summary}

The interactions of transition metals with the prion protein $(\mathrm{PrP})$ are well-documented and described; however, there is no consensus on their role in either the physiology of PrP or PrP-related neurodegenerative disorders. Reports revealed an interaction of PrP with transition metals and showed a protective role of $\mathrm{PrP}^{\mathrm{C}}$ against cellular stresses, especially, against oxidative damage, which is perhaps one of the most widely accepted functions of $\operatorname{PrP}^{\mathrm{C}}$. Zpl cells are hippocampus-derived $\mathrm{Prnp}^{-/-}$immortalized cells that have been shown to be more vulnerable to apoptotic cell death than their $\operatorname{PrP}^{\mathrm{C}}$-expressing counterparts. Here we used this model system to investigate whether these cells lacking PrP are more vulnerable to metal-induced toxicities as well. We selected four metals $\mathrm{Cu}^{2+}, \mathrm{Mn}^{2+}, \mathrm{Co}^{2+}$ and $\mathrm{Zn}^{2+}$ and used the alamarBlue viability assay and a propidium iodide-based dye exclusion assay, along with examining the overall morphological changes induced by the application of various concentrations of the four transition metals.

PrP-expressing ZW cells established from WT mice were shown to be more resistant to all four metal ions tested in comparison to $\operatorname{Prnp}^{-/-} \mathrm{Zpl}$ cells. Further, we introduced PrP or only the empty vector into Zpl cells by sleeping beauty (SB) transposase based system to generate stabile transgenic cell lines (Zpl 2-1-PrP and Zpl 2-1-vector cells). PrP-expressing Zpl 2-1-PrP cells did not show any increased significant resistant to $\mathrm{Cu}^{2+}, \mathrm{Zn}^{2+}, \mathrm{Mn}^{2+}$ and $\mathrm{Co}^{2+}$ induced toxicities than its control $\mathrm{Zpl} 2-1-\mathrm{vector}$ cells and we could not recognize any protective effects associated with the presence of PrP. This observation was further corroborated when assessing the toxic effect of metals by propidium-iodide staining and fluorescence activated cell sorting analysis. Based on these results we could not establish a clear link between prion protein expression and an increased resistance to metal toxicity that is seen in the case of $\mathrm{ZW}$ cells, since PrP expression does not confer increased resistance to 
$\mathrm{Zpl}$ cells as compared to GFP expression alone. Thus, the increased resistance of ZW cells are either not related to $\operatorname{PrP}^{\mathrm{C}}$ expression, or at least $\mathrm{PrP}^{\mathrm{C}}$ expression is not the sole factor necessary for the increased resistance.

When the same studies were performed using SH-SY5Y cell line, a neuroblastoma model system, PrP expression rendered the cells more resistant against $\mathrm{Cu}^{2+} \mathrm{Zn}^{2+}, \mathrm{Mn}^{2+}$ and $\mathrm{Co}^{2+}$ compared to vector expressing control cells at all concentrations of the metal ions that fall into the toxic ranges for the cells.Also, they showed significantly more resistance if compared to the mother SH-SY5Y cells.

Altogether, our results do not seem to support a general protective role for PrP against transition metal toxicity and also, we emphasize the necessity of extreme care when comparing cells derived from PrP knock-out and wild type mice. 


\section{0. Összefoglalás}

A prion fehérje $(\operatorname{PrP})$ átmeneti fémekkel való kölcsönhatása jól dokumentált, számos vizsgálati eredmény írja le kölönböző aspektusait. Ennek ellenére nincs konszenzus a tekintetben, hogy ezek a kölcsönhatások pontosan milyen fiziológiás szerepet töltenek be, valamint, hogy milyen kapcsolatban állnak a neurodegenaratív betegségekkel. Az egészséges, celluláris $\operatorname{PrP}\left(\mathrm{PrP}^{\mathrm{C}}\right)$ számos eddig leírt, valószínűsített funkciója közül talán a stresszhatásokkal szembeni sejt-védelem, ezen belül főleg az antioxidáns szerep az ami leginkább dokumentált. Tekintve, hogy az átmeneti fém-toxicitás a szabadgyökök generálásán keresztül valósul meg, valamint, maga a prion fehérje fémkötőhelyekkel rendelkezik, elképzelhető, hogy a $\mathrm{PrP}^{\mathrm{C}}$ a fémtoxicitás elleni védelemben is szerepet játszik. A Zpl sejtek egér hippocampus -eredetü Prnp ${ }^{-}$- immortalizált sejtek, amelyekről kimutatták, hogy érzékenyebbek az apoptotikus sejthalálra mint a PrP -t expresszáló kontroll sejtek. Ezt a sejtkultúra-modellrendszert választottuk ki a jelen munkában, annak vizsgáltára, hogy vajon a fémtoxicitással szemben is érzékenyebbek-e a $\operatorname{Prnp}^{-1}$ - sejtek. A vizsgálatokhoz négy különböző átmeneti fémet választottunk ki: $\mathrm{Cu}^{2+}, \mathrm{Mn}^{2+}, \mathrm{Co}^{2+}$ és $\mathrm{Zn}^{2+}$, melyeket különböző kocentrációkban alkalmaztunk, és három különböző vizsgálati módszert: az alamarBlue-alapú esszét a sejtek életképességének vizsgálatára, a propídium jodid festék-kizárás módszerét az elpusztult sejtek megbecsülésére, valamint, mikroszkópos morfológiai vizsgálatokat, a sejtek állapotának a morfológiai jellemzőkön keresztüli nyomonkövetésére.

Kimutattunk, hogy a PrP -t expresszáló ZW kontroll sejtvonal, melyet a vad típusú (WT) egerekből hoztak létre, jobban ellenáll mind a négy tesztelt fémion hatásának a Prnp ${ }^{-/-}$ Zpl sejtekhez képest. Továbbá, bevezetettük a PrP gént, vagy csak az üres vektort, Zpl sejtekbe csipkerózsika (SB) transzpozáz-fehérje alapú rendszert alkalmazva, és stabil transzgenikus sejtvonalakat hoztunk létre (Zpl 2-1-PrP és Zpl 2-1 -vektor sejtek). Azt találtuk, hogy a PrP-t expresszáló Zpl 2-1 -PrP transzgenikus sejtek nem mutattak semmilyen 
jelentősen megnövekedett rezisztenciát a $\mathrm{Cu}^{2+}, \mathrm{Zn}^{2+}, \mathrm{Mn}^{2+}$ és $\mathrm{Co}^{2+}$ által indukált toxicitással szemben, a kontroll Zpl 2-1 - vektor sejtekhez képest, a PrP jelenlétének semmilyen mentő hatását nem tapasztaltuk. Ezt a megfigyelést támasztotta alá a propidium jodid alapú fluoreszcens sejtanalízis eredménye is amikor ugyanazon fémek toxicitását teszteltük ezzel a módszerrel. Az eredményeink alapján így nem tudtunk közvetlen párhuzamot vonni a PrP jelenléte és a fémek toxicitásával szembeni, ZW sejtek esetében tapasztalt, megnövekedett ellenállóképesség között, mivel hogy a PrP-expresszáló transzgenikus sejtvonal a vektor-, csak GFP-t expresszáló sejtvonalhoz képest, nem mutatott rezisztenciát a fémekkel szemben. Ezek alpján azt a következtetést vonhatjuk le, hogy a ZW sejtek esetében tapasztalt fémionokkal szembeni magasabb rezisztencia a PrP-null sejtvonalhoz képest, vagy nem a PrP jelenlétének tulajdonítható, vagy legalábbis a PrP jelenléte nem az egyedüli faktor ami a fémek toxicitásával szembeni ellenálását meghatározza.

Amikor ugyanazon vizsgálatokat egy neuroblasztóma modell rendszeren az SH-SY5Y sejtvonalon végeztünk, a PrP-t expresszálló transzgenikus sejtvonal ellenállóbbá tette a sejteket a $\mathrm{Cu}^{2+} \mathrm{Zn}^{2+}, \mathrm{Mn}^{2+}$ és $\mathrm{Co}^{2+}$ hatásával szemben, a csak vektort expresszáló kontroll sejtekhez képest, valamennyi azon fémion koncentrációk esetében melyek a toxikus tartományokba estek. A PrP-t expresszáló sejtek szignifikánsan nagyobb ellenállást mutattak az anya, SH- SY5Y, sejtekkel összehasonlítva is.

Összevetve, eredményeink nem támasztják alá azt, hogy a prion fehérje általános mentő-szerepet töltene be fém-toxicitás esetén. E mellett, felhívja a figyelmet arra, hogy hasonló vizsgálatok során körültekintőnek kell lenni arra, hogy megfelelő kontroll sejtrendszereket válasszunk a vizsgálatokhoz. 


\section{Appendix}

\section{$\underline{\text { Statement }}$}

The results presented in this thesis originate from the work I have done in the Laboratory of Conformational Diseases of Ervin Welker, between 2010-2015 at the Institute of Biochemistry, BRC, Szeged. Majority of the experiments were conceived, designed and performed by myself, such as the transition metal treatments, viability and cell death assays, immunocytochemistry and confocal microscopy analyses, western blots, with the exception of the design and engineering of the DNA-constructs and generation of the transgenic cell lines which were made by Antal Nyeste. I had analysed and statistically evaluated all the data obtained.

The major part of the results presented in the thesis were published in my first author publication,

Cingaram, P.K.R., Nyeste, A., Dondapati, D.T., Fodor, E., and Welker, E. (2015). Prion Protein Does Not Confer Resistance to Hippocampus-Derived Zpl Cells against the Toxic Effects of $\mathrm{Cu}^{2+}, \mathrm{Mn}^{2+}, \mathrm{Zn}^{2+}$ and $\mathrm{Co}^{2+}$ Not Supporting a General Protective Role for PrP in Transition Metal Induced Toxicity. PLoS One 10, e0139219,

whereas, some of the data, comprising the studies on the SH-SY5Y cell lines, are unpublished.

In this study I also used some microscopy techniques that I have optimized during my one year work at the Laboratory of Cellular Imaging of BRC, between 2008 and 2009, by which I contributed to a publication with co-authorship:

Molnár, E., Kuntam, S., Cingaram, P.K.R., Peksel, B., Suresh, B., Fábián, G., Fehér, L.Z., Bokros, A., Medgyesi, Á., Ayaydin, F., et al. (2013). Combination of small molecule microarray and confocal microscopy techniques for live cell staining fluorescent dye discovery. Molecules 18, 9999-10013.

I have used none of the results included in the thesis for obtaining any other degree.

Pradeep Kumar Reddy Cingaram

Szeged, 2015.12.17 